\title{
Neobvyklá žilná Cu-Zn-Ag-Pb-As-Sb-Se-Sn-Bi mineralizace z Jedové jámy u Vejprt v Krušných horách (Česká republika)
}

\author{
Unusual vein Cu-Zn-Ag-Pb-As-Sb-Se-Sn-Bi mineralization from Jedová jáma mine \\ near Vejprty in the Krušné hory Mts. (Czech Republic)
}

\author{
Petr Pauliš ${ }^{1,2) *}$, Zdeněk Dolníček ${ }^{2)}$, Roman GrambličKa ${ }^{3)}$ a OndŘej Pour ${ }^{4)}$ \\ 1)Smíškova 564, 28401 Kutná Hora; *e-mail: petr.paulis@post.cz \\ ${ }^{2}$ Mineralogicko-petrologické oddělení, Národní muzeum, Cirkusová 1740, 19300 Praha 9 - Horní Počernice \\ 3) Severočeské doly a.s., ul. 5. května 213, 41829 Bílina \\ 4) Česká geologická služba, Geologická 6, 15200 Praha 5
}

Pauliš P, Dolniček Z, Gramblička R, Pour O (2020) Neobvyklá žilná Cu-Zn-Ag-Pb-As-Sb-Se-Sn-Bi mineralizace z Jedové jámy u Vejprt v Krušných horách (Česká republika). Bull Mineral Petrolog 28(2): 385-405 ISSN 2570-7337

\begin{abstract}
An extraordinary rich mineral assemblage consisting of 27 minerals has been newly discovered in quartz veins of the abandoned ore deposit, once exploited by the Drei König Mine, called also Giftschacht (Jedová jáma - Toxic shaft), situated approximately $2 \mathrm{~km}$ SE of Vejprty town. It includes 16 sulphides (plus one unnamed) with far prevailing arsenopyrite. In addition to common sulphides (chalcopyrite, sphalerite, galena and minerals of the tetrahedrite group), a wide suite of sulphosalts with substantial Bi-content was identified. Besides common bismuthinite and emplectite, also relatively rare Bi minerals (matildite, aikinite, hammarite, wittichenite), in the Czech Republic known from few localities only, have been found here. $\mathrm{Bi}$ is bound also in a rather exotic selenide bohdanowitzite and native bismuth. $\mathrm{Bi}$ is substantially present in some domains of tetrahedrites [tetrahedrite-(Zn), tennantite-(Zn) and tennantite-(Fe)]. In addition to local Bi enrichment, also Sn-minerals occur in the ore, represented by cassiterite and rare sulphides (kësterite and stannoidite). The presence of phosphates of the plumbogummite group [plumbogummite, goyazite and florencite-(Ce)] contributes to the remarkable mineral assemblage. From geochemical point of view, very interesting is the presence of florencite-(Ce), in which REE with dominating $\mathrm{Ce}$ are fixed. In addition, grains of fluorite, fluorapatite, rutile, topaz and aggregates of illite and a phase from kaolinite group are present. Supergene mineralization is represented besides limonite by abundant scorodite and rare strengite.
\end{abstract}

Key words: arsenopyrite deposit, sulphidic mineralization, Bi-Sn mineralization, minerals of the plumbogummite group, Jedová jáma mine near Vejprty, Krušné hory Mts., Czech Republic

Obdrženo 26. 10. 2020; prijato 7. 12. 2020

\section{Úvod}

Přibližně 2 km jv. od Vejprt a cca $600 \mathrm{~m}$ sz. od Přísečnické hory (854 m n.m.) (GPS: $50^{\circ} 29^{\prime} 0.7^{\prime \prime} \mathrm{N}, 13^{\circ} 3^{\prime} 9.6^{\prime \prime} \mathrm{E}$; obr. 1) se nachází málo známá lokalita arsenové mineralizace. Jde o starý opuštěný důl označovaný v minulosti jako Dreikönig, Harald či Giftschacht (Jedová jáma), který je součástí černopotockého revíru. Poprvé se o něm zmiňují Fritsch a Pöschl (1813 in Jangl 1957) jako o dole Dreikönigschachte, později jej uvádí Jokély (1857) jako důl Drei König. Podle něho sestával důl z těžní šachty $22 \mathrm{~m}$ hluboké, ze které byla sv. směrem vyražena sledná chodba, a ze dvou větracích jam. Patrně jde o starý důl, zmáhaný v letech 1811 a 1843 (Kořan 1947) a v první polovině 20. století pak důlní společností Argenta, kterou založil ing. Goettel. Ten tu po skončení první světové války, kdy byla v sousedním Sasku velká poptávka po arsenových ru-

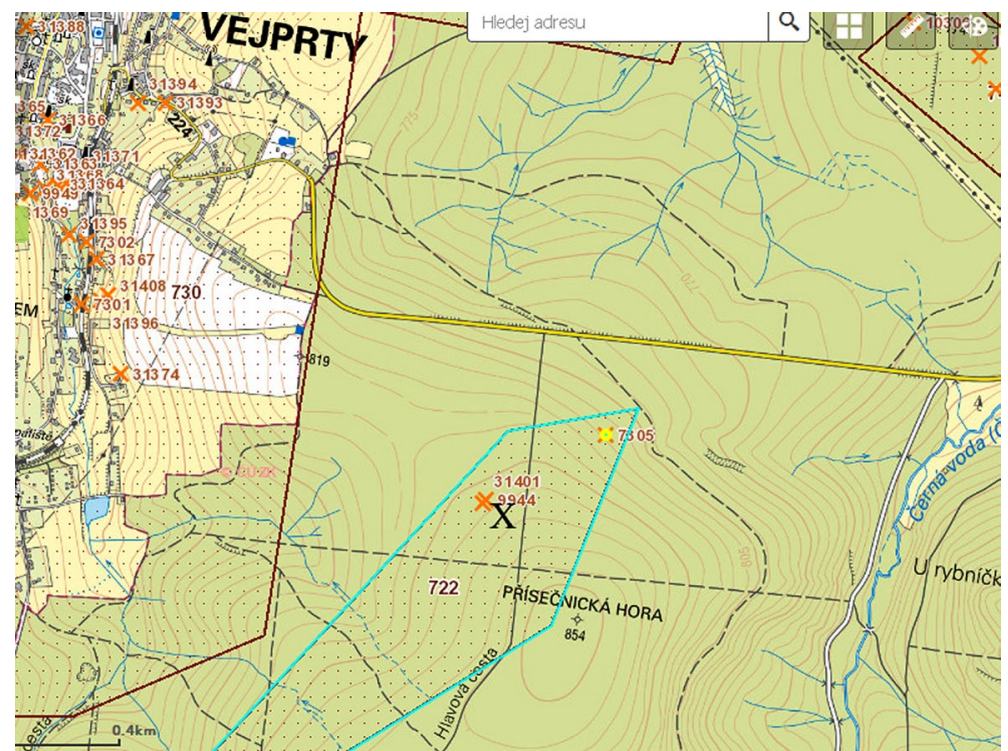

Obr. 1 Geografická pozice studované lokality (označena X) (https:// mapy.geology.cz/dulni_dila_poddolovani). 


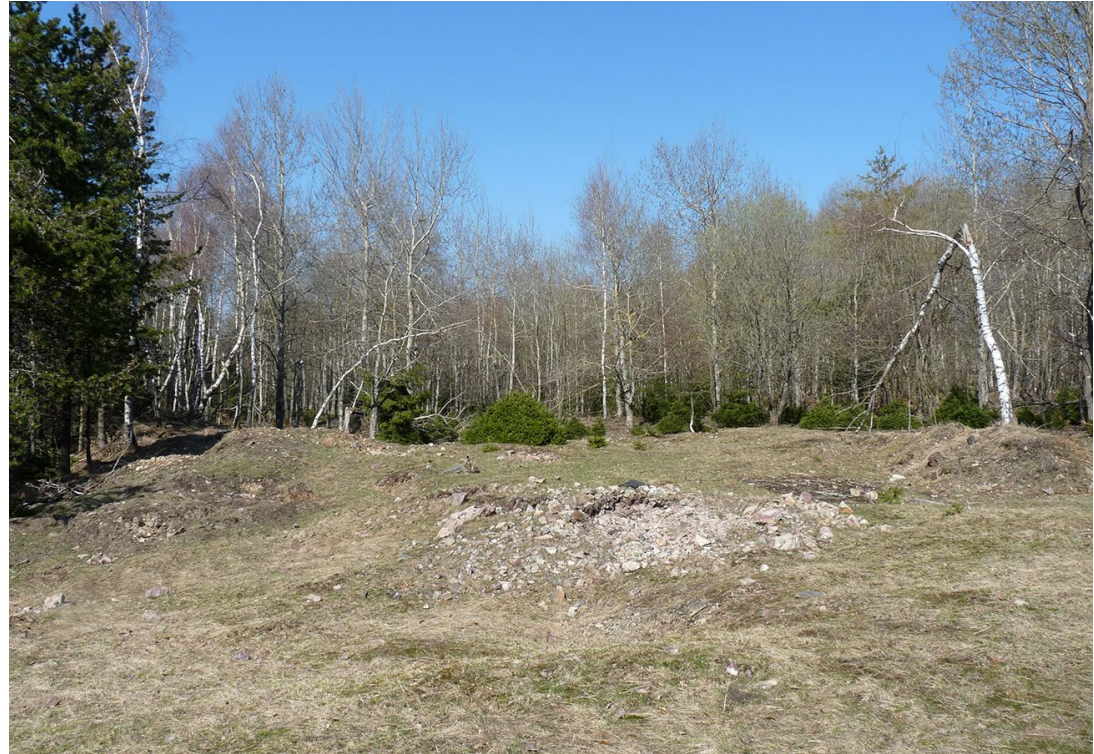

Obr. 2 Zbytky odvalů u Jedové jámy u Vejprt, foto P. Pauliš (2019).

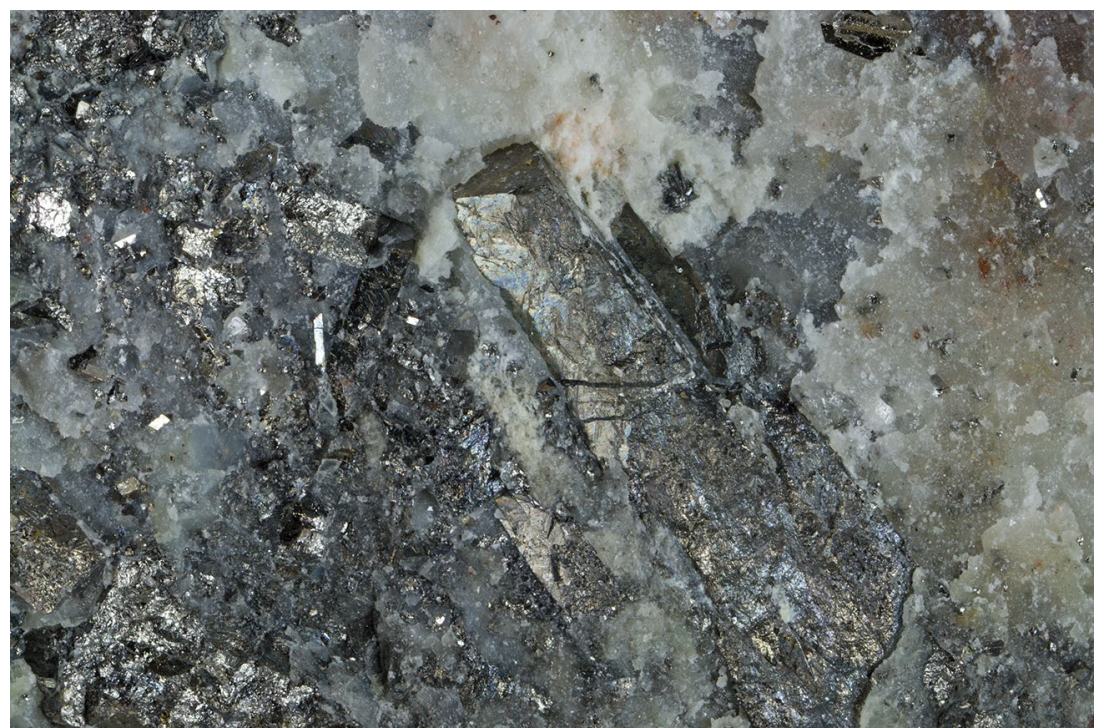

Obr. 3 Krystal arsenopyritu z Jedové jámy u Vejprt; šírka záběru 10 mm, foto P. Fuchs.

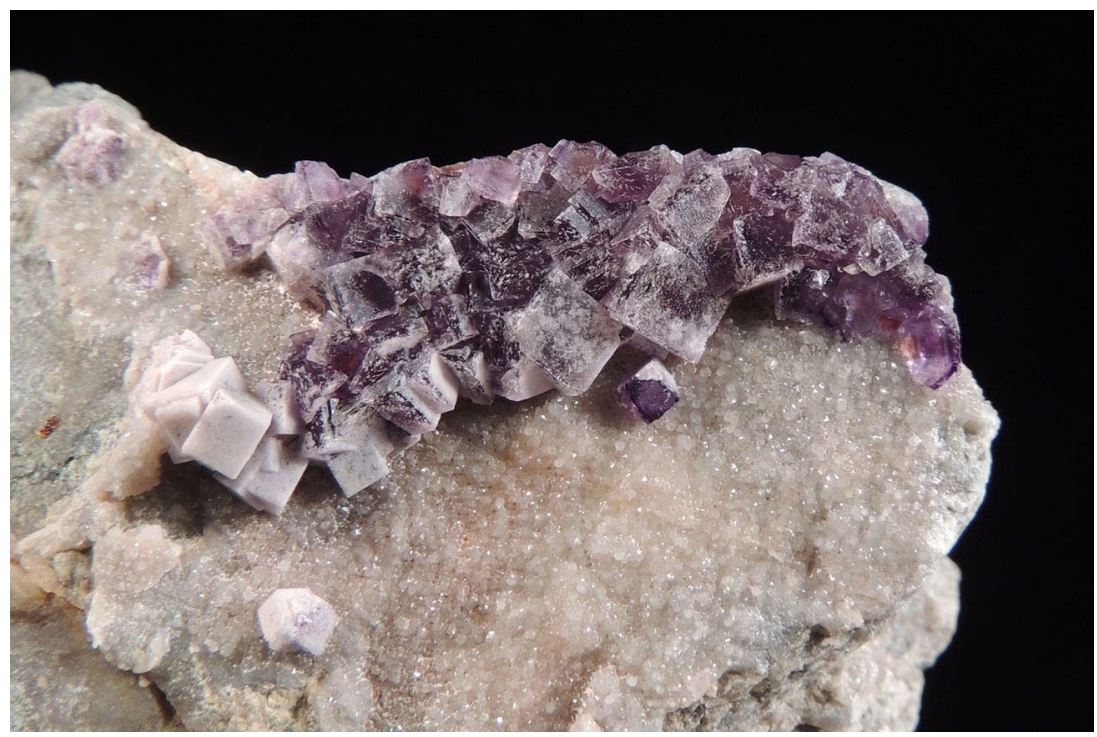

Obr. 4 Drúza kubických krystalů fluoritu na křemeni z Jedové jámy u Vejprt; šiřka záběru $36 \mathrm{~mm}$, foto $R$. Gramblička. dách, zahájil čerpání důlních vod a malotěžbu. Poté, co se 10. července 1924 v tomto dole otrávilo šest horníků zplodinami benzinového motoru čerpadla, však byla těžba ukončena (Hrabánek 2006). V roce 1964 byl důl vyzmáhán pracovníky Geologického průzkumu $v$ rámci prospekce na fluorit, přičemž bylo zjištěno, že zrudněná zóna $s$ arsenopyritem byla $\checkmark$ minulosti sledována $v$ délce $60 \mathrm{~m}$ (Velebil, Přibil 2012). V registru důlních děl a poddolování ČGS - Geofondu jsou vyznačeny $v$ těsném sousedství dvě jámy - větrací (č. 9944) a těžní (č. 31401). Do současnosti se tu zachovaly dvě šachetní ústí zakrytá betonovými deskami. Většina rudního materiálu byla po ukončení průzkumných prací odvezena, zbylá část haldy rozhrnuta (informace V. Šrein) (obr. 2). Přesto Ize $v$ terénu $\checkmark$ okolí šachet najít typické ukázky zdejšího zrudnění, především arsenopyritu a supergenního skoroditu.

\section{Geologie a mineralogie ložiska}

Z geologického hlediska je tato oblast budována především metamorfovanými proterozoickými a paleozoickými horninami krušnohorského krystalinika. Proterozoické horniny v Krušných horách tvoří prísečnickou skupinu, v jejíž spodní části se vyčleňuje rusovské souvrství tvořené převážně muskoviticko-biotitickými pararulami a tělesy přeměněných bazických vulkanitů, křemenců, černých břidlic a drob. Nadložní měděnecké souvrství má ve spodní části ortoruly (metamorfované ryolity), ve vyšších partiích se nalézá pestrý sled různých typů pararul s tělesy metadrob, krystalických vápenců, bazických metavulkanitů a metakonglomerátů (Chlupáč et al. 2011). Území je porušeno soustavou zlomů dvou hlavních směrů: SZ - JV až SSZ - JJV a Z - V až ZJZ - VSV, které posloužily jako přívodní dráhy jak pro deskovitá tělesa granitových porfyrů a křemenných žil, tak pro válcovitá tělesa neovulkanitů, které svým složením vesměs odpovídají alkalickým bazaltoidům (nefelinity, bazanity až tefrity) oligocénního až miocénního stáŕí, které jsou vázány na riftový vulkanismus oherského riftu (Malkovský et al. 1985).

Vlastní ložisko je tvořeno Jedovou žílou, která má směr $15-20^{\circ}$, sklon $90^{\circ}$, mocnost až přes $2 \mathrm{~m}$. $\checkmark$ oblasti Jedové jámy je její vývoj znám $v$ délce cca $60 \mathrm{~m}$. Jde spíš o pásmo drobných výplní poruch, v jejichž okolí došlo k alteraci rul, $\mathrm{k}$ jejich vybělení a prokřemenění. Vedle 
arsenopyritu obsahuje též pyrit a opál. Drobné žilky a proniky fialového fluoritu jsou patrně starší než arsenopyritové zrudnění (Bouška in Mayerová, Mayer 1967). Podle bývalého zaměstnance Argenty $\mathrm{J}$. Weisbacha zde bylo nalezeno i ryzí stříbro. Tento nález by potvrzovaly $\mathrm{i}$ vysoké obsahy Ag ve vzorcích, které si nechala společnost Argenta analyzovat (Mayerová, Mayer 1967). Fluorit tvoří pouze povlaky a drobná zrna $v$ křemenné žilovině, obsahy $\mathrm{CaF}_{2}$ nepřekračovaly $5 \%$. Arsenopyrit, jako dominující sulfid, tu tvoři masivní akumulace $v$ prokřemenělé hydrotermálně alterované rule. Zóna se zrudněním směru SV - JZ tu údajně dosahovala mocnosti kolem $4 \mathrm{~m}$ (Jokély 1857). Žilná struktura tu vystupuje v muskovitických pararulách krušnohorského krystalinika. Nověji se výzkumu této lokality věnovali Gramblička et al. (2015), kteří popisují bohaté impregnace arsenopyritu v křemeni i okolní hornině, které místy přecházejí v téměř litou rudu. $\mathrm{Na}$ puklinách tvoří arsenopyrit prizmatické krystaly do $5 \mathrm{~mm}$ velikosti, vzácněji do $1 \mathrm{~cm}$ (obr. 3). Provází ho drobně krystalovaný křemen a jílové minerály. Křemen se zde vyskytuje nejméně ve dvou generacích. První impregnuje ruly a na puklinách tvoři prizmatické krystaly do $5 \mathrm{~mm}$ délky, druhá generace křemene tvoři tenké palisádovité žilky s drobnými krystaly, na které nasedají hematit a fluorit. Vzácnějším sulfidem je pyrit, tvořící zrna a na puklinách zploštělé krystaly a agregáty do $10 \mathrm{~mm}$. Poměrně častý je na tenkých křemenných žilkách hematit, nejčastěji v podobě lesklých černých, radiálně paprsčitých agregátů až $5 \mathrm{~mm}$ mocných. Vzácnější jsou až $5 \mathrm{~mm}$ velké kulovité agregáty hematitu, složené z drobných krystalů. Na těchto žilkách se vyskytuje i fluorit, tvořící bělavé až bledě fialové kubické krystaly, maximálně $4 \mathrm{~mm}$ veliké (obr. 4). $Z$ dalších minerálů tu byly na reliktech hald zjištěny baryt, drobné sloupečky fluorapatitu, zrnitý a drobně krystalovaný chalkopyrit, drobná zrna tetraedritu a černý sfalerit. $\mathrm{K}$ nejzajímavějším minerálům patří emplektit (obr. 5), tvořící vzácně shluky kovově šedých jehličkovitých krystalů až $5 \mathrm{~mm}$ dlouhých, které jsou někdy povlečeny opálem (obr. 6). Ze supergenních minerálů byly zjištěny pouze limonit a skorodit (obr. 7 ), který je tu velice hojný a ve formě bledě šedozelených bradavčitých povlaků obaluje úlomky zrudněných rul (Gramblička et al. 2015).

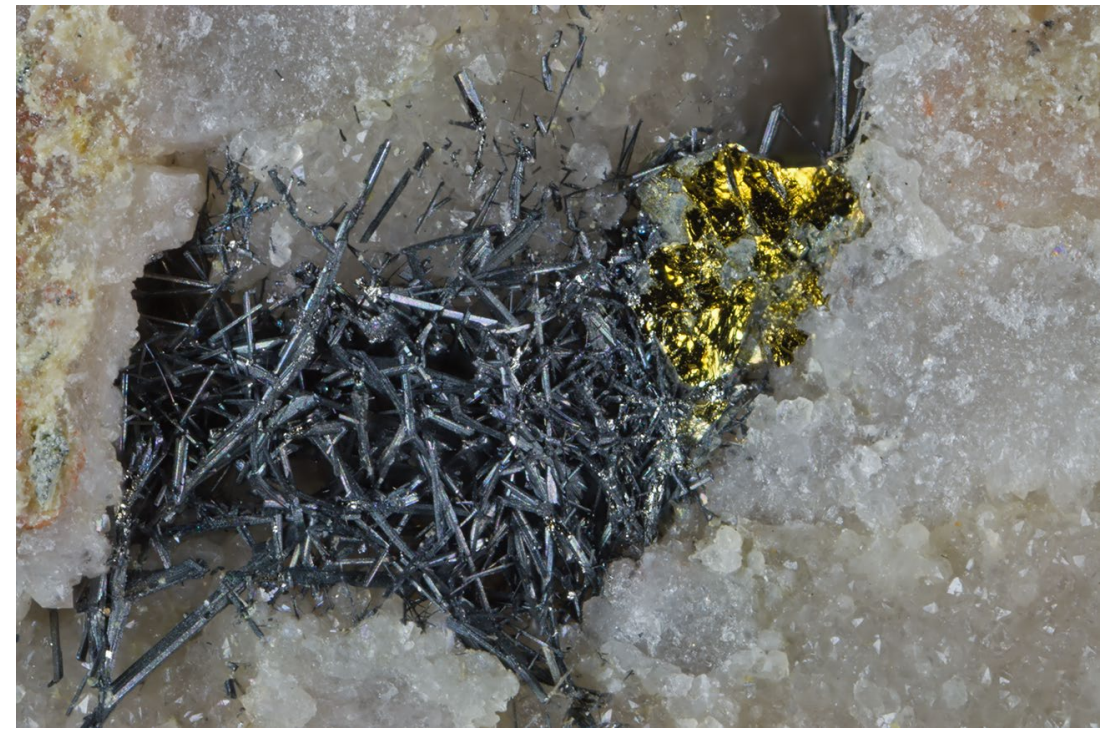

Obr. 5 Jehličkovité krystaly emplektitu z Jedové jámy; šířka záběru 4.8 mm, foto P. Fuchs.

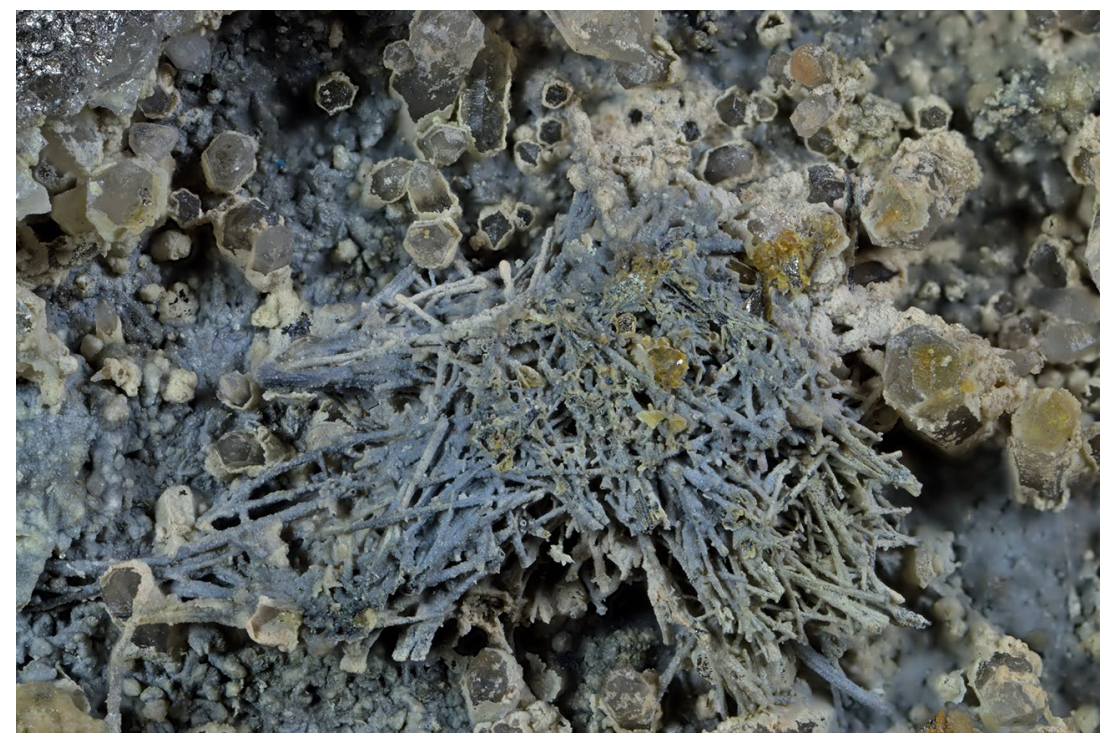

Obr. 6 Jehličkovité krystaly emplektitu povlečené opálem z Jedové jámy; šiřka záběru $10 \mathrm{~mm}$, foto $B$. Bureš.

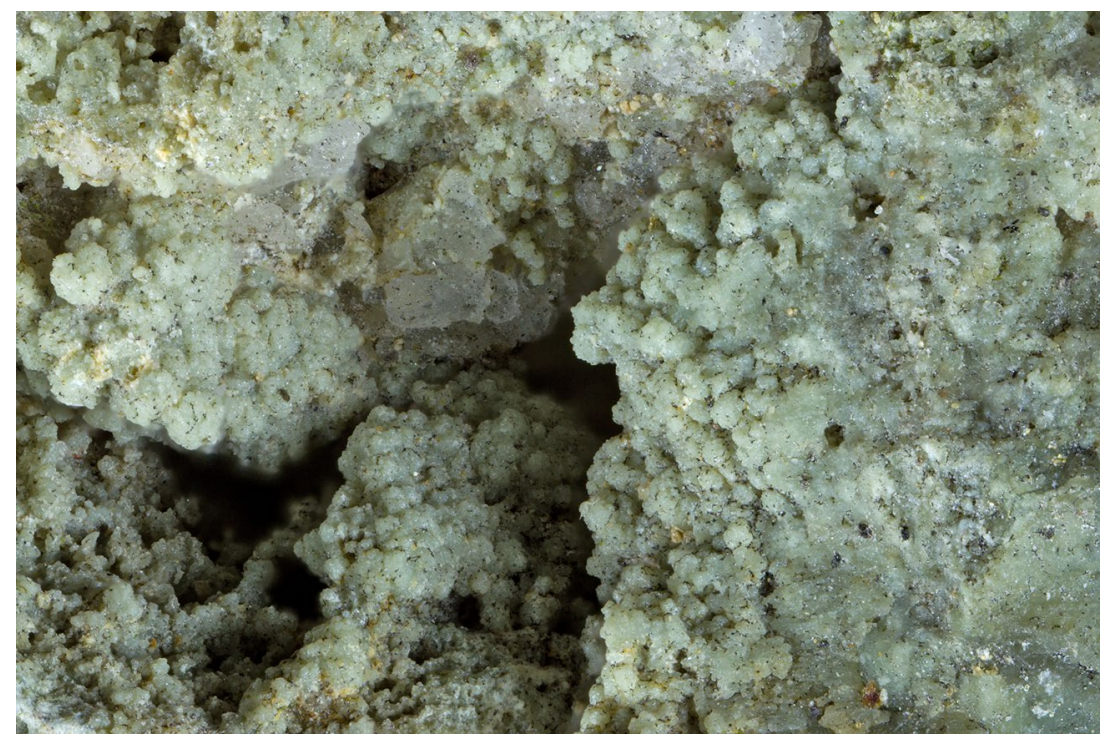

Obr. 7 Povlaky skoroditu na křemeni z Jedové jámy; šírka záběru 8 mm, foto P. Fuchs. 


\section{Metodika výzkumu}

Makroskopicky patrné minerály a zajímavé nábrusy pro následné stanovení chemického složení pomocí elektronové mikrosondy byly identifikovány mikroskopem Tescan Mira3 GMU s energiově disperzním spektrome-

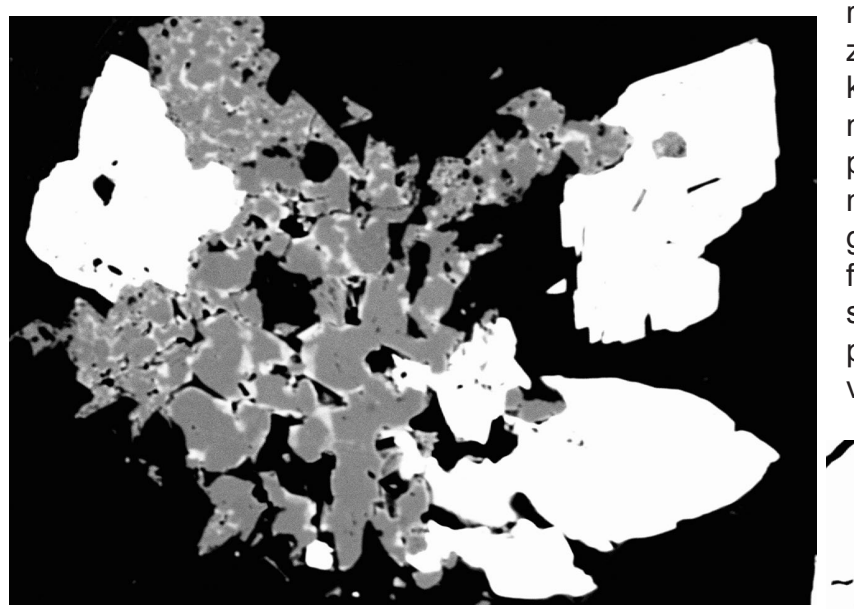

Obr. 8 Arsenopyrit (bílý) srůstající se zrny rutilu (tmavošedý), která jsou lemována rutilem se zvýšenými obsahy W, Cr a V (světle šedý); Jedová jáma; šírka záběru $250 \mu \mathrm{m}$, foto $v$ BSE Z. Dolníček.

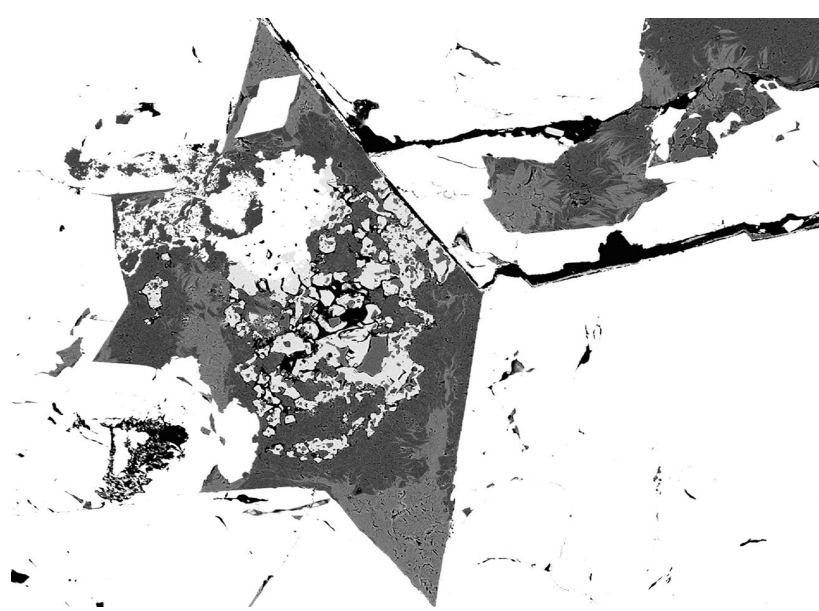

Obr. 9 Arsenopyrit (billý) s fluoritem (středně šedý) a illitem (tmavošedý) v křemeni (nejtmavši); Jedová jáma; šírka záběru $1100 \mu m$, foto v BSE Z. Dolníček.

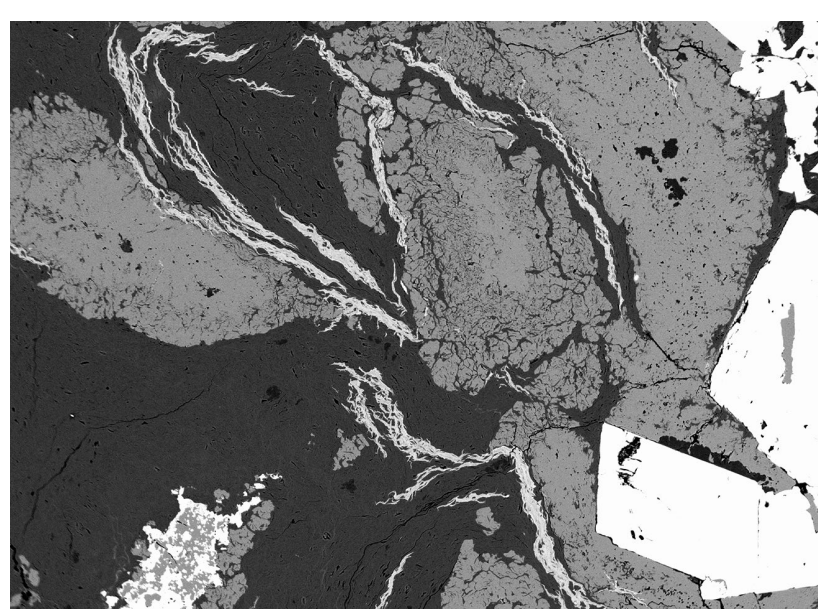

Obr. 10 Arsenopyritové krystaly (bílé), fluoritové agregáty (šedé) a žilkovité agregáty goyazitu (světle šedý) v illitu (tmavošedý); Jedová jáma; šírka záběru 1500 m, foto v BSE Z. Dolníček. trem Oxford Instruments X-Max 20 v laboratoři České geologické služby (operátor $O$. Pour).

Nábrusy vzorků byly studovány pomocí elektronové mikrosondy Cameca SX-100 v laboratoři Mineralogicko -petrologického oddělení Národního muzea v Praze (operátor Z. Dolníček). Na prístroji byly pořízeny fotografie ve zpětně odražených elektronech (BSE) a měřeno chemické složení jednotlivých fází ve vlnově disperzním (WDS) modu. Při bodových analýzách kyslíkatých minerálů bylo použito urychlovací napětí $15 \mathrm{kV}$, proud svazku $5 \mathrm{nA}$ (minerály plumbogummitové skupiny, fluorit, skorodit-strengit), $10 \mathrm{nA}$ (apatit, silikáty), respektive $20 \mathrm{nA}$ (oxidy) a fokusovaný (oxidy), respektive defokusovaný elektronový svazek o průměru $2 \mu \mathrm{m}$ (apatit, silikáty) či $5 \mu \mathrm{m}$ (minerály plumbogummitové skupiny, fluorit, skorodit-strengit). Ve všech analýzách silikátů byly měřeny obsahy $\mathrm{Al}, \mathrm{Ba}, \mathrm{Ca}$,

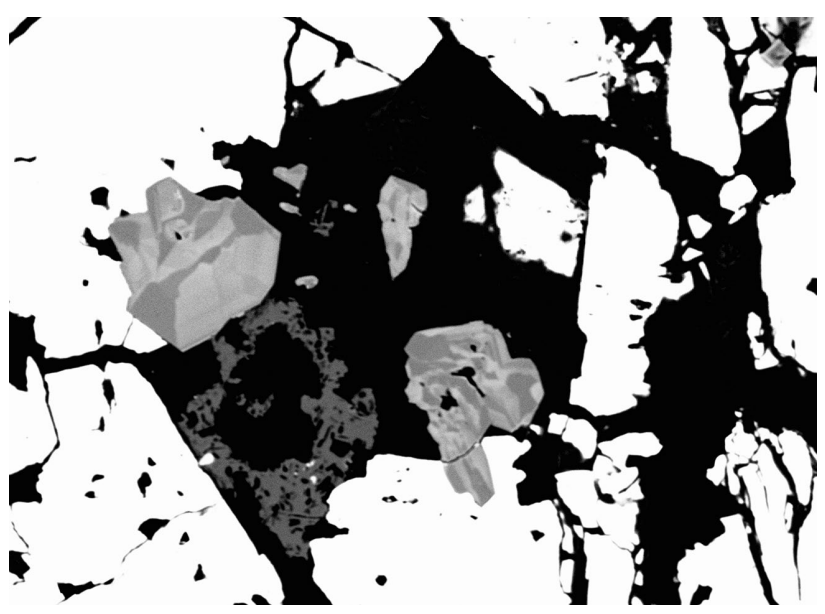

Obr. 11 Arsenopyrit (bilý) s automorfními zonálními krystaly rutilu, $v$ kterých se střídají čisté zóny (tmavošedé) s partiemi se zvýšenými obsahy $W$ (světlejší), $v$ kremeni je též zarostlý korodovaný agregát fluoritu (tmavošedý); Jedová jáma; šířka záběru $350 \mu \mathrm{m}$, foto v BSE Z. Dolníček.

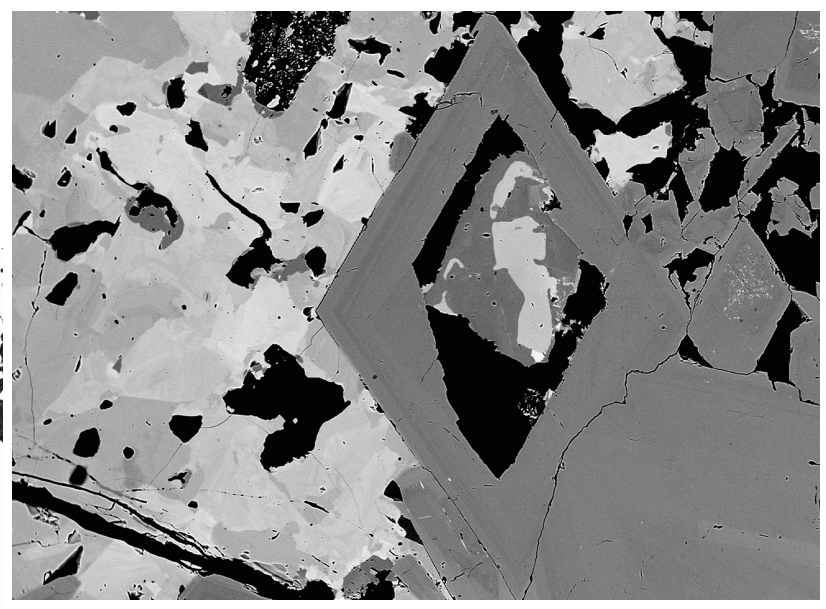

Obr. 12 Arsenopyritové zrno a korodovaný krystal (tmavě šedý) částečně vyplněný tennantitem-(Zn) (bez Bi) (obdobné šedosti jako arsenopyrit) srůstající s tetraedrit-tennantitem-(Zn) (cca $2 \%$ Bi)(bělošedý), drobná bilá inkluze ve spodní části jeho zrna je Bi bohatý tennantit (17\% Bi); v levé polovině snímku je zachycen zonální agregát tetraedrit-tennantitu, $s$ variabilním obsahem Bi (od bělošedé s $3 \%$ Bi po středně šedé bez Bi); Jedová jáma; šírka záběru $1100 \mu \mathrm{m}$, foto v BSE Z. Dolníček. 
$\mathrm{Co}, \mathrm{Cu}, \mathrm{Cl}, \mathrm{Cr}, \mathrm{Cs}, \mathrm{F}, \mathrm{Fe}, \mathrm{K}, \mathrm{Mg}, \mathrm{Mn}, \mathrm{N}, \mathrm{Na}, \mathrm{Ni}, \mathrm{P}, \mathrm{Pb}, \mathrm{Rb}$, $\mathrm{Si}, \mathrm{Ti}, \mathrm{V}$ a $\mathrm{Zn}, \mathrm{v}$ apatitech $\mathrm{Al}, \mathrm{Ba}, \mathrm{Ca}, \mathrm{Cl}, \mathrm{F}, \mathrm{Fe}, \mathrm{Mg}, \mathrm{Mn}$, $\mathrm{Na}, \mathrm{P}, \mathrm{S}, \mathrm{Si}$ a Sr, v rutilech a dalších oxidech $\mathrm{Al}, \mathrm{As}, \mathrm{Ca}$, $\mathrm{Cr}$, Fe, Mg, Mn, Mo, Na, Nb, P, Pb, S, Sc, Si, Sn, Ta, Ti, $\mathrm{U}, \mathrm{V}, \mathrm{W}, \mathrm{Y}$ a Zr, v minerálech plumbogummitové skupiny a ve fluoritu $\mathrm{Al}, \mathrm{As}, \mathrm{Ba}, \mathrm{Bi}, \mathrm{Ca}, \mathrm{Ce}, \mathrm{Cl}, \mathrm{Cl}, \mathrm{Eu}, \mathrm{F}, \mathrm{Fe}, \mathrm{Gd}, \mathrm{K}$, $\mathrm{La}, \mathrm{Mg}, \mathrm{Mn}, \mathrm{N}, \mathrm{Na}, \mathrm{Nd}, \mathrm{P}, \mathrm{Pb}, \mathrm{Pr}, \mathrm{Rb}, \mathrm{S}, \mathrm{Si}, \mathrm{Sm}, \mathrm{Sr}, \mathrm{V}, \mathrm{W}$, $\mathrm{Y}$ a Zn a v minerálech řady skorodit-strengit byly měřeny obsahy $\mathrm{Al}, \mathrm{As}, \mathrm{Ba}, \mathrm{Bi}, \mathrm{Ca}, \mathrm{Cl}, \mathrm{Co}, \mathrm{Cr}, \mathrm{Cu}, \mathrm{F}, \mathrm{Fe}, \mathrm{K}, \mathrm{Mg}$, $\mathrm{Mn}, \mathrm{N}, \mathrm{Na}, \mathrm{Ni}, \mathrm{P}, \mathrm{Pb}, \mathrm{S}, \mathrm{Si}, \mathrm{Sn}, \mathrm{Sr}, \mathrm{Th}, \mathrm{Ti}, \mathrm{U}, \mathrm{V}, \mathrm{Y}$ a Zn. Použité analytické čáry a standardy: albit $(\mathrm{NaK \alpha})$, almandin $(\mathrm{AlK} \alpha, \mathrm{Fe} K \alpha)$, apatit $(\mathrm{P} K \alpha)$, baryt $(\mathrm{Ba} L \beta), \mathrm{Bi}(\mathrm{Bi} M \alpha), \mathrm{BN}$ $(\mathrm{N} K \alpha), \mathrm{CePO}_{4}(\mathrm{Ce} L \alpha)$, celestin (SKa, $\left.\mathrm{Sr} L \beta\right)$, Co $(\mathrm{CoK} \alpha)$, $\mathrm{Cr}_{2} \mathrm{O}_{3}(\mathrm{CrK} \alpha), \mathrm{CrTa}_{2} \mathrm{O}_{6}(\mathrm{Ta} L \alpha)$, Cs-sklo (CsL $\left.\alpha\right)$, diopsid $(\mathrm{MgK} \alpha)$, halit $(\mathrm{Cl} K \alpha), \mathrm{EuPO}_{4}(\mathrm{EuL} \alpha), \mathrm{GdPO}_{4}(\mathrm{Gd} L \alpha)$, hematit (FeKa), chalkopyrit (CuKa), klinoklas (AsLa), , LaPO (LaL $\alpha), \mathrm{LiF}(\mathrm{FK} \alpha), \mathrm{NdPO}_{4}(\mathrm{Nd} L \alpha), \mathrm{Ni}(\mathrm{NiK \alpha}), \mathrm{PrPO}_{4}(\mathrm{Pr} L \alpha)$, $\mathrm{Rb}-\mathrm{Ge}$-sklo $(\mathrm{Rb} L \alpha)$, rodonit $(\mathrm{MnK} \alpha)$, sanidin $(\mathrm{KK} \alpha), \mathrm{ScVO}_{4}$ $(\mathrm{ScK} \alpha)$, scheelit $(\mathrm{W} L \alpha), \mathrm{SmPO}_{4}(\mathrm{Sm} L \alpha), \mathrm{Sn}(\mathrm{Sn} L \alpha)$, Th $(\mathrm{Th} M \alpha), \mathrm{TiO}_{2}(\mathrm{Ti} K \alpha), \mathrm{UO}_{2}(\mathrm{U} M \alpha)$, vanadinit $(\mathrm{Pb} M \alpha, \mathrm{V} K \alpha)$, wollastonit (CaKa, SiKa), wulfenit (MoLa, $\mathrm{PbM \alpha}), \mathrm{YVO}_{4}$ $(\mathrm{Y} L \alpha)$, zinkit $(\mathrm{ZnK} \alpha)$ a zirkon $(\mathrm{Zr} L \alpha)$. Prri bodových analýzách sulfidů, selenidů a ryzích kovů bylo použito urych-

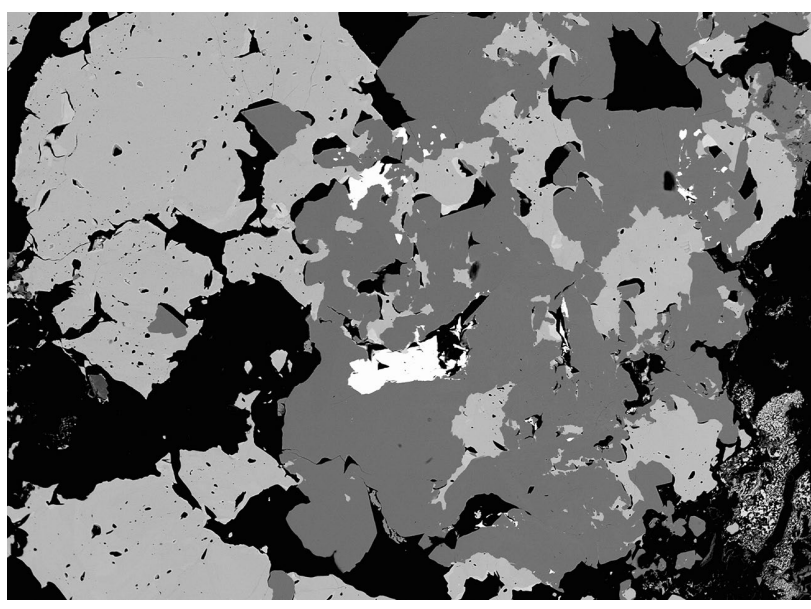

Obr. 13 Agregát chalkopyritu (tmavě šedý), matilditu (bílý) a tetraedrit-tennantitu-(Zn) (středně šedý); Jedová jáma; šiřka záběru 1700 m, foto v BSE Z. Dolníček.

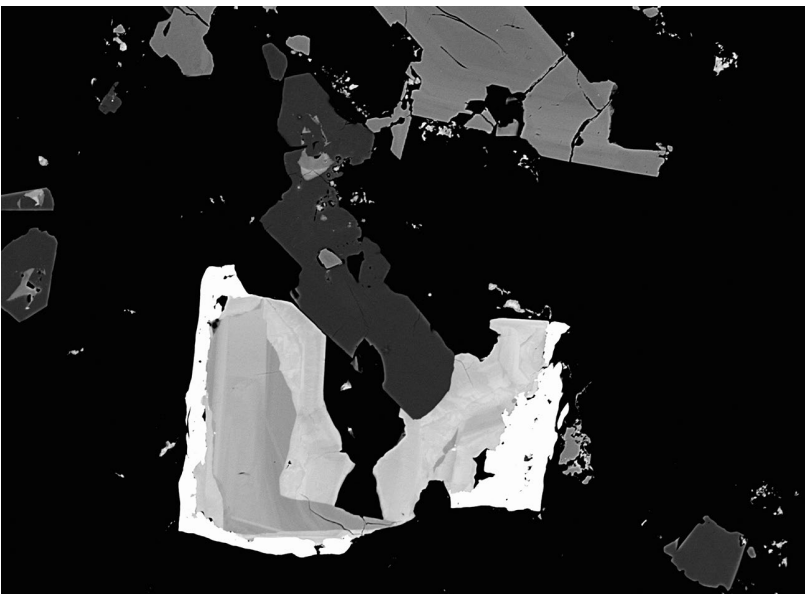

Obr. 14 Zonální zrna tvořená matilditem při okraji (bílý) a tetraedritem-(Zn) s vyšším obsahem Bi (světle šedý) a tetraedritem-(Zn) s nízkým Bi, která srůstaji s chalkopyritem (černošedý), v horní části je ještě zachycen krystal arsenopyritu (tmavošedý); Jedová jáma; šiřka záběru $570 \mu \mathrm{m}$, foto v BSE Z. Dolníček.

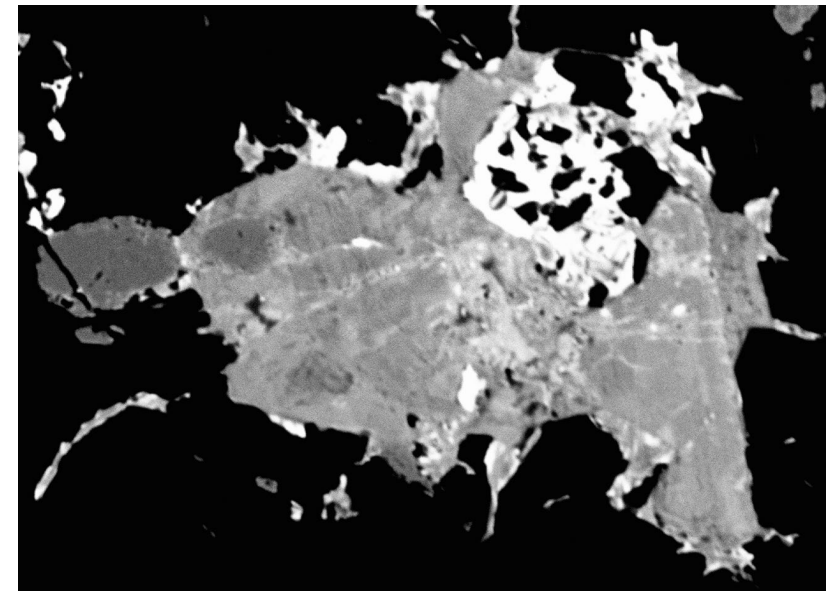

Obr. 15 Zonální zrno florencitu-(Ce) (šedé) srůstající s chalkopyritem (bílý) a chemicky čistým rutilem (tmavě šedý); Jedová jáma; šírka záběru $170 \mu \mathrm{m}$, foto v BSE Z. Dolníček.

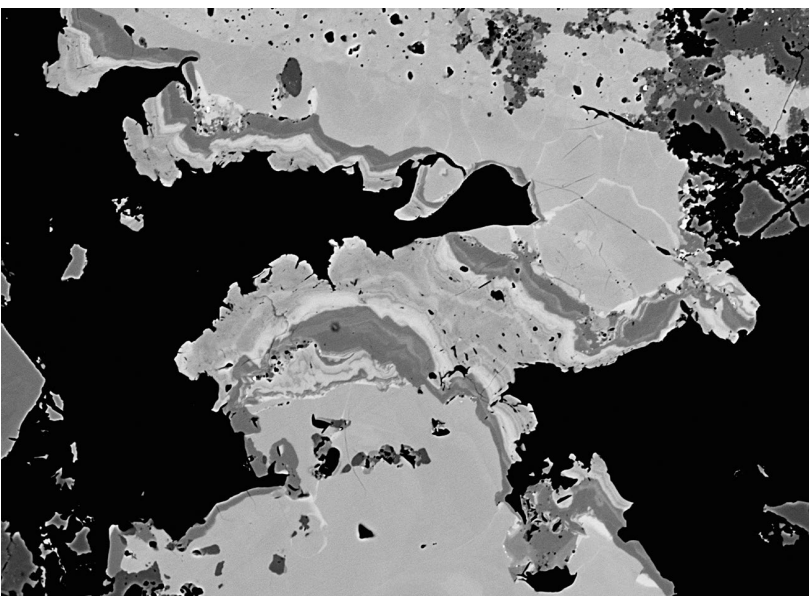

Obr. 16 Zonální agregát tvořený tetraedrit-tennantitem-(Zn) bez Bi, ve světlejších partiích prevládá tetraedritová složka, $v$ tmavších tennantitová složka, $v$ pravém horním rohu je agregát sfaleritu (tmavošedý); Jedová jáma; šířka záběru $450 \mu \mathrm{m}$, foto v BSE Z. Dolníček.

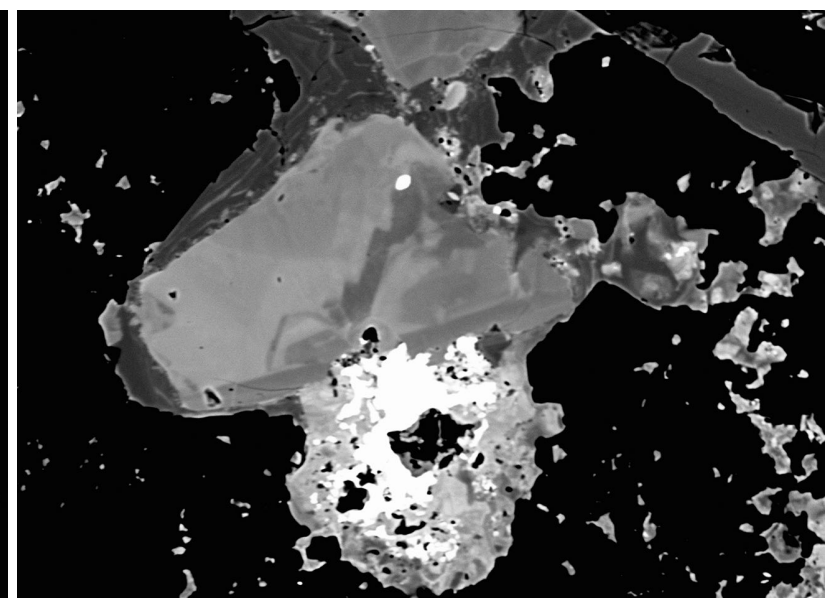

Obr. 17 Zrno aikinitu (bílé) lemované Bi-bohatým tennantitem-(Zn) (18\% Bi) (středně šedé) srůstající se zrnem tetraedrit-tennantitu-(Zn) s cca $8 \%$ Bi (tmavošedé) a tennantitu-(Zn) bez Bi (černošedé) s malou inkluzi galenitu (bilá); Jedová jáma; šiřka záběru 350 $\mu m$, foto v BSE Z. Dolníček. 
lovací napětí $25 \mathrm{kV}$, proud svazkem 20 nA (sulfidy, ryzí $\mathrm{Bi})$, respektive $10 \mathrm{nA}$ (selenidy) a průměr elektronového svazku $1 \mu \mathrm{m}$. V sulfidech, selenidu a ryzím Bi byly měřeny obsahy Ag, As, Au, Bi, Cd, Cl, Co, Cu, Fe, Ga, Ge, Hg, In, Mn, $\mathrm{Ni}, \mathrm{Pb}, \mathrm{S}, \mathrm{Sb}, \mathrm{Se}, \mathrm{Sn}, \mathrm{Te}$ a $\mathrm{Zn}$. Použité standardy a analytické čáry: $\mathrm{Ag}(\mathrm{AgL} \alpha), \mathrm{Au}(\mathrm{AuM} \alpha), \mathrm{Bi}_{2} \mathrm{Se}_{3}(\mathrm{Bi} M \beta)$, CdTe $(\mathrm{Cd} L \alpha)$, Co $(\mathrm{CoK} \alpha)$, $\mathrm{CuFeS}_{2}(\mathrm{CuK \alpha}, \mathrm{SK} \alpha), \mathrm{FeS}_{2}$ (FeKa), GaAs $(\mathrm{GaL} \alpha)$, Ge $(\mathrm{Ge} L \alpha)$, HgTe $(\mathrm{Hg} L \alpha)$, InAs $(\ln L \alpha), \mathrm{Mn}(\mathrm{MnK} \alpha), \mathrm{NaCl}(\mathrm{Cl} K \alpha)$, NiAs $(\mathrm{As} L \beta), \mathrm{Ni}(\mathrm{NiK} \alpha)$, $\mathrm{PbS}(\mathrm{PbM} \alpha)$, $\mathrm{PbSe}(\mathrm{Se} L \beta), \mathrm{PbTe}(\mathrm{Te} L \alpha), \mathrm{Sb}_{2} \mathrm{~S}_{3}(\mathrm{Sb} L \alpha)$, $\mathrm{Sn}(\mathrm{Sn} L \alpha), \mathrm{TI}(\mathrm{Br}, \mathrm{l})(\mathrm{TI} L \alpha)$ a ZnS $(\mathrm{ZnK} \alpha)$. Načtená data byla přepočítána na $\mathrm{hm}$. \% s použitím standardní PAP korekce (Pouchou, Pichoir 1985). Získaná data byla korigována na koincidence $P$ vs. Ca, La vs. Dy, Eu vs. Dy, $\mathrm{F}$ vs. Ce, Bi vs. Ce a Th vs. U. Obsahy výše uvedených prvků, které nejsou uvedeny $v$ tabulkách, byly ve všech případech pod mezí stanovitelnosti, která se pohybovala pro většinu prvků obvykle mezi 0.03 a $0.1 \mathrm{hm}$. $\%$, v některých př́padech však byly hodnoty limitu stanovitelnosti i vyšší (např. těžší REE až kolem 0.3 hm. \%).

Obsahy REE ve florencitu byly normalizovány na C1 chondrit s použitím hodnot Anderse a Grevesseho (1989). Velikosti Eu a Ce anomálií byly kvantifikovány pomocí vztahů uváděných např. McLennanem (1989).

Tabulka 1 Chemické složení sfaleritu (Sp) a galenitu (Ga) z Jedové jámy. Obsahy v hm. \%, hodnoty apfu jsou vypočítány na základ dvou atomů na vzorcovou jednotku.

\begin{tabular}{lrrrrrrrrrr}
\hline An. č. & 1 & 2 & 3 & 4 & 5 & 6 & 7 & 8 & 9 & 10 \\
Minerál & $\mathrm{Sp}$ & $\mathrm{Sp}$ & $\mathrm{Sp}$ & $\mathrm{Sp}$ & $\mathrm{Ga}$ & $\mathrm{Ga}$ & $\mathrm{Ga}$ & $\mathrm{Ga}$ & $\mathrm{Ga}$ & $\mathrm{Ga}$ \\
\hline $\mathrm{Zn}$ & 63.83 & 61.75 & 63.38 & 64.36 & 0.00 & 0.00 & 0.00 & 0.00 & 0.00 & 0.00 \\
$\mathrm{Fe}$ & 0.13 & 0.28 & 0.46 & 0.41 & 0.11 & 1.26 & 0.46 & 0.82 & 0.09 & 0.09 \\
$\mathrm{Cu}$ & 0.41 & 1.50 & 0.80 & 0.05 & 0.22 & 0.13 & 0.05 & 0.41 & 0.52 & 0.45 \\
$\mathrm{Cd}$ & 0.72 & 0.66 & 0.62 & 0.73 & 0.00 & 0.00 & 0.00 & 0.00 & 0.00 & 0.00 \\
$\mathrm{Ag}$ & 0.00 & 0.00 & 0.00 & 0.00 & 0.34 & 0.32 & 0.94 & 0.80 & 1.85 & 1.97 \\
$\mathrm{~Pb}$ & 0.00 & 0.00 & 0.00 & 0.00 & 84.66 & 80.28 & 82.31 & 83.58 & 79.94 & 79.89 \\
$\mathrm{Bi}$ & 0.00 & 0.00 & 0.00 & 0.00 & 0.72 & 4.44 & 2.06 & 1.80 & 4.06 & 4.12 \\
$\mathrm{~S}$ & 33.02 & 32.82 & 33.09 & 33.06 & 13.89 & 13.93 & 13.76 & 13.92 & 13.94 & 14.00 \\
$\mathrm{Se}$ & 0.00 & 0.00 & 0.00 & 0.00 & 0.00 & 0.13 & 0.15 & 0.13 & 0.07 & 0.04 \\
\hline Total & 98.11 & 97.01 & 98.35 & 98.61 & 99.94 & 100.49 & 99.73 & 101.46 & 100.48 & 100.56 \\
\hline $\mathrm{Zn}$ & 0.966 & 0.943 & 0.956 & 0.970 & 0.000 & 0.000 & 0.000 & 0.000 & 0.000 & 0.000 \\
$\mathrm{Fe}$ & 0.002 & 0.005 & 0.008 & 0.007 & 0.005 & 0.032 & 0.019 & 0.033 & 0.004 & 0.004 \\
$\mathrm{Cu}$ & 0.006 & 0.024 & 0.012 & 0.001 & 0.008 & 0.005 & 0.002 & 0.015 & 0.019 & 0.016 \\
$\mathrm{Cd}$ & 0.006 & 0.005 & 0.005 & 0.005 & 0.000 & 0.000 & 0.000 & 0.000 & 0.000 & 0.000 \\
$\mathrm{Ag}$ & 0.000 & 0.000 & 0.000 & 0.000 & 0.007 & 0.007 & 0.020 & 0.017 & 0.040 & 0.040 \\
$\mathrm{~Pb}$ & 0.000 & 0.000 & 0.000 & 0.000 & 0.956 & 0.888 & 0.928 & 0.921 & 0.889 & 0.887 \\
$\mathrm{Bi}$ & 0.000 & 0.000 & 0.000 & 0.000 & 0.008 & 0.049 & 0.023 & 0.020 & 0.045 & 0.046 \\
\hline Catsum & 0.980 & 0.977 & 0.981 & 0.983 & 0.984 & 0.981 & 0.992 & 1.006 & 0.997 & 0.993 \\
\hline $\mathrm{S}$ & 1.019 & 1.022 & 1.019 & 1.022 & 1.013 & 0.996 & 1.003 & 0.990 & 1.001 & 1.004 \\
Se & 0.000 & 0.000 & 0.000 & 0.000 & 0.000 & 0.004 & 0.004 & 0.004 & 0.002 & 0.001 \\
\hline Ansum & 1.019 & 1.022 & 1.019 & 1.022 & 1.013 & 1.000 & 1.007 & 0.994 & 1.003 & 1.005 \\
\hline
\end{tabular}

Tabulka 2 Chemické složení tetraedritu-(Zn) a Bi-bohatého tetraedritu-(Zn) z Jedové jámy. Obsahy v hm. \%, hodnoty apfu jsou vypočitány na základ 16 atomů kovů a metaloidů na vzorcovou jednotku.

\begin{tabular}{|c|c|c|c|c|c|c|c|c|c|c|c|c|c|c|}
\hline \multirow{2}{*}{$\begin{array}{l}\text { An. č. } \\
\text { Minerál }\end{array}$} & & 1 & 2 & 3 & 4 & 5 & 0 & \multirow{2}{*}{\multicolumn{7}{|c|}{ Bi-bohatý tetraedrit-(Zn) }} \\
\hline & & & & & & & & & & & & & & \\
\hline$\overline{\mathrm{Ag}}$ & 1.35 & 1.00 & 1.3 & 25 & 4 & 5 & 1.92 & 1.67 & 1.40 & 1.61 & 1.67 & 1.83 & 1.75 & 1.7 \\
\hline 4 & 36.1 & 37.53 & .51 & 36.24 & 35.62 & 35.18 & .00 & & & 5.06 & .12 & 34.46 & 34.41 & 33.79 \\
\hline & 78 & .22 & 63 & .46 & 51 & .46 & 19 & 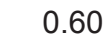 & & 40 & 65 & .79 & .57 & 0.5 \\
\hline & & .19 & & & 8 & 78 & & & & & & .52 & & 6.3 \\
\hline & 00 & 0.00 & 0.00 & 0.00 & 0.00 & 0.00 & 0.00 & 0.12 & 0 & 0.15 & 0.12 & 0.15 & 0.13 & 0.1 \\
\hline & 71 & 91 & 4.6 & 4. & 2.87 & 3. & & & & 71 & .79 & .48 & .03 & 4.2 \\
\hline & 20 & .53 & 45 & 2 & 6.79 & 7 & 1 & & & 98 & .23 & .67 & .79 & 2.86 \\
\hline & .72 & .90 & .89 & 36 & .98 & 56 & 82 & 05 & 20 & 31 & .49 & .71 & 37 & 4.21 \\
\hline & 68 & .50 & 88 & 67 & 27 & & & 32 & & 98 & 01 & .87 & 93 & 5.7 \\
\hline ota & .23 & 98.78 & 39 & .03 & .06 & .20 & 24 & 98.13 & 76 & 97.78 & 97.56 & 98.48 & 97.44 & $99.6 \varepsilon$ \\
\hline$g$ & 3 & 53 & 212 & 8 & 6 & 5 & & 4 & & .265 & 72 & 02 & 39 & 0.29 \\
\hline & 95 & 31 & 77 & 25 & 57 & 94 & 8 & 68 & & 30 & 99 & 45 & 74 & 9.52 \\
\hline & 39 & 0.359 & 0.187 & & & & & & & 27 & 0.204 & 51 & & .17 \\
\hline & 34 & 1.560 & 1797 & & 9 & & & & & 6 & 39 & 73 & 65 & 1.75 \\
\hline & 00 & 0.000 & 0.000 & 00 & 00 & & & & & 23 & 0.019 & 0.023 & 0.020 & 0.01 \\
\hline & 72 & 1.519 & 1.053 & & & & & & & 0.873 & 1.121 & & & 1.01 \\
\hline & 0.424 & 0.120 & 0.197 & .368 & .566 & & 0.771 & 0.931 & & 0.843 & 0.858 & 0.992 & 1.000 & 1.10 \\
\hline & 2.622 & 2.557 & 2.887 & 2.711 & 2.857 & 2.525 & 2.103 & 2.188 & 2.186 & 2.363 & 2.088 & 2.188 & 2.100 & 2.09 \\
\hline & 13.122 & 13.104 & 13.055 & 13.121 & 13.176 & 13.233 & 13.069 & 3.427 & 13.299 & 13.190 & 13.140 & 13.240 & 13.333 & 13.35 \\
\hline
\end{tabular}




\section{Výsledky mineralogického výzkumu}

Mineralogické složení žiloviny bylo studováno na šesti nábrusech zhotovených ze vzorků nasbíraných $v$ roce 2019 spoluautorem publikace (RG). Vzorky, které jsou na povrchu značně navětrané, jsou tvořené z hlavní části bělošedou křemennou žilovinou, ve které jsou makroskopicky patrné až několik $\mathrm{cm}$ velké, jemně zrnité, ocelově šedé agregáty arsenopyritu, místy $\mathrm{i}$ jeho až několik $\mathrm{mm}$ velké krystaly. Úlomky rudniny jsou na povrchu pokryty hnědými povlaky limonitu a bílými a světle zelenými práškovitými či celistvými povlaky skoroditu. Některé vzorky obsahují drobné agregáty jemných světlých slíd, fragmenty alterovaných rul a povlaky jílových minerálù. Vedle dominujícího arsenopyritu obsahují některé vzorky rudnin též až několik mm velké jemnozrnné agregáty pyritu, tmavošedé, kovově lesklé, jemnozrnné agregáty tetraedritu a maximálně $2 \mathrm{~mm}$ velká zlatavá, nepravidelně omezená zrna chalkopyritu. Mineralogický výzkum byl zaměřen na vzorky chudší arsenopyritem, ve kterých bylo možné makroskopicky předpokládat př́tomnost minerálů tetraedritové řady, prrípadně další vzácnější mineralizace. $V$ tomto směru byly výsledky výzkumu překvapující především zjištěním řady sulfidů obsahujících $\mathrm{Bi}, \mathrm{z}$ nichž některé nebyly dosud $v$ tomto regionu zjištěny.

Naprosto dominujícím rudním minerálem žiloviny je arsenopyrit, který $v$ nábrusech tvoří většinou až několik $\mathrm{mm}$ velká zrna a až $1 \mathrm{~mm}$ velké automorfní krystaly kosočtverečného průřezu zarůstající do křemenné žiloviny (obr. 8, 9, 10). Srůstá se zrny rutilu (obr. 8, 11), fluoritu (obr. 10), chalkopyritu a tetraedritu. Některé krystaly jsou zonální a korodované. $\checkmark$ jedné jeho drobné korozní dutině byl zjištěn tennantit-(Zn) a tetraedrit -tennantit-(Zn) (obr. 12) a fluorit (obr. 9). Jde o nejstarší sulfid studované asociace. Chemické složení arsenopyritu odpovídá ideálnímu vzorci tohoto minerálu. Nebyly $v$ něm zjištěny žádné príměsi. Průměrný (osm bodových analýz) empirický vzorec arsenopyritu je možno na bázi 3 apfu vyjádřit jako $\mathrm{Fe}_{0.99} \mathrm{As}_{1.02} \mathrm{~S}_{0.99}$.

$\checkmark$ podstatně menším množství byl $v$ rudnině zastižen chalkopyrit. Tvoři až $1 \mathrm{~mm}$ velká nepravidelná členitá zrna s xenomorfním a hypautomorfním omezením, která se vyskytuji samostatně $v$ křemenné žilovině, narůstají na arsenopyritové krystaly či zarůstají do tennantitu. Srůstají též $\mathrm{s}$ tetraedritem a matilditem (obr. $13,14)$ či florencitem-(Ce) (obr. 15). $\checkmark$ BSE obraze je chalkopyrit nezonální. Při studiu jeho chemického složení byla vedle $\mathrm{Cu}, \mathrm{Fe}$ a $\mathrm{S}$ zjištěna pouze minoritní příměs $\mathrm{Pb}$ (0.001 apfu). Průměrný (pět bodových analýz) empirický vzorec chalkopyritu z Jedové jámy je možno na bázi 4 apfu vyjádřit jako $\mathrm{Cu}_{0.99} \mathrm{Fe}_{0.98} \mathrm{~S}_{2.02}$.

$\mathrm{V}$ míře ještě menší byla $\mathrm{v}$ nábrusech zastižena nepravidelná xenomorfní zrna sfaleritu. Jsou maximálně 70 $\mu \mathrm{m}$ velká, srůstají s tennantitem či tetraedritem při okraji jejich zrn (obr. 16). V BSE obraze jsou nezonální. Při studiu chemického složení sfaleritu (tab. 1) byla vedle $\mathrm{Zn}$ a $S$ zjištěna pouze minoritní příměsi $\mathrm{Fe}(0.002-0.008$ apfu), Cu (0.001 - 0.024 apfu) a Cd (0.005 - 0.006 apfu). Průměrný (čtyři bodové analýzy) empirický vzorec sfaleritu z Jedové jámy je možno na bázi 2 apfu vyjádřit jako $\left(\mathrm{Zn}_{0.99} \mathrm{Fe}_{0.01} \mathrm{Cu}_{0.01} \mathrm{Cd}_{0.01}\right)_{\Sigma 1.02} \mathrm{~S}_{1.02}$.

Velmi vzácně se v nábrusech uplatňuje galenit, tvořící ojedinělá, velmi malá, xenomorfně omezená nezonální zrna o rozměrech do $10 \mu \mathrm{m}$ zarůstající do tennantitu-(Zn) či tetraedritu-(Zn) s malým či nulovým obsahem Bi (obr. 17). Vedle $\mathrm{Pb}$ a S obsahuje galenit nízké koncentrace $\mathrm{Ag}$ (0.007 - 0.040 apfu), Fe (0.004 - 0.033 apfu), Cu (0.002 -
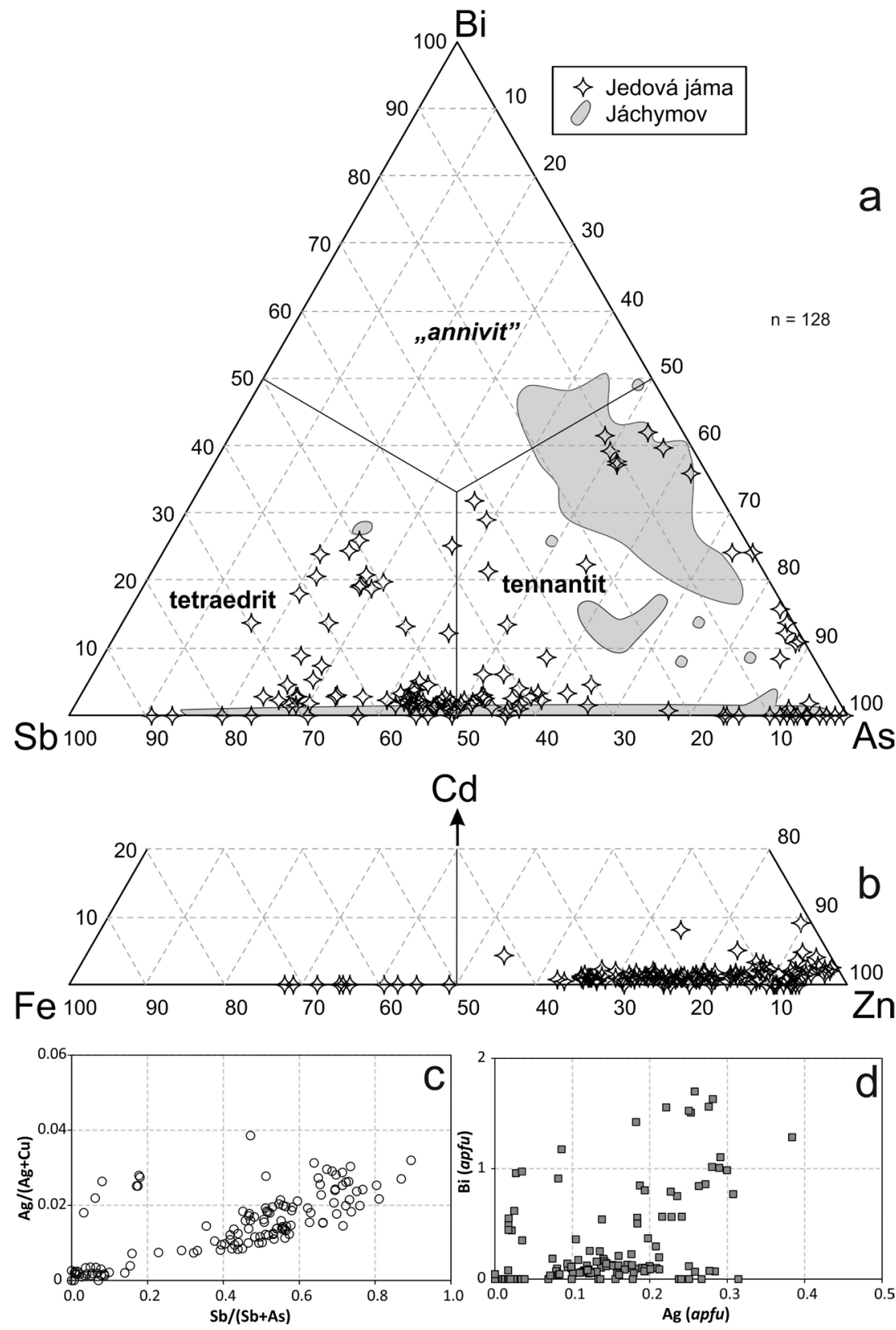

Obr. 18 Variabilita $v$ chemismu minerálů tetraedritové skupiny z Jedové jámy. a - diagram Sb - As - Bi, srovnávací data pro jáchymovský revír jsou z práce Velebila a Sejkory (2018); b - diagram $\mathrm{Fe}-\mathrm{Zn}$ - Cd; c - diagram $\mathrm{Ag} /(\mathrm{Ag}+\mathrm{Cu})$ vs. $S b /(S b+A s) ; d$ - diagram $A g-B i$. 
0.019 apfu), Bi (0.008 - 0.049 apfu) a Se (0 - 0.004 apfu) (tab. 1).

Poměrně často jsou v nábrusech zastoupeny minerály tetraedritové skupiny. $V$ některých nábrusech jsou hlavními sulfidickými minerály. Podle BSE snímků jsou minerály této skupiny chemicky zonální. Zonalita je vyvolána především změnami poměru $\mathrm{Sb} / \mathrm{As}$, $\mathrm{Bi} / \mathrm{Sb}$, respektive Bi/As a v menší míře $\mathrm{Zn} / \mathrm{Fe}$. Zjištěny tu byly většinou tetraedrity-(Zn) a tennantity-(Zn), v menším množství pak tetraedrity-(Zn), tennantity-(Zn) a -(Fe) se zvýšenými až vysokými obsahy $\mathrm{Bi}$. Celkem bylo pořízeno 128 analýz minerálů tetraedritové skupiny. Po jejich vynesení do diagramu Sb - As - Bi (obr. 18a) je zřejmé, že jich většina odpovídá Bi chudým přechodným členům tetraedritového a tennantitového chemismu. Bi bohaté fáze se uplatňují v malém množství jak u tetraedritů, tak u tennantitů. Několik Bi bohatých tennantitů se blíží hranici pole Bi analogu tetraedritu (tzv. annivitu), ale oproti vzorkům z Jáchymova (Velebil, Sejkora 2018) ji nepřekračují. Z diagramu Fe Zn - Cd (obr. 18b) vyplývá, že naprostá většina tetraedrit/ tennantitů spadá mezi zinečnaté členy s poměrně nízkým obsahem Fe. Z diagramu závislosti $\mathrm{Ag} /(\mathrm{Ag}+\mathrm{Cu})$ vs. Sb/ $(\mathrm{Sb}+\mathrm{As})$ (obr. 18c) Ize usuzovat na prímou úměru mezi obsahy Ag a Sb. Naproti tomu zřetelná závislost mezi obsahy Ag a Bi nebyla zjištěna (obr. 18d).

Reprezentativní příklady chemického složení jednotlivých druhů, respektive variet minerálů tetraedritové skupiny jsou představeny $v$ tabulkách 2 až 4 .

Tabulka 3 Chemické složení tennantitu-(Zn) a fází na přechodu tennantit-(Zn)-tetraedrit-(Zn) z Jedové jámy. Obsahy $v \mathrm{hm}$. \%, hodnoty apfu jsou vypočítány na základ 16 atomů kovů a metaloidů na vzorcovou jednotku.

\begin{tabular}{|c|c|c|c|c|c|c|c|c|c|c|c|c|c|c|}
\hline \multirow{2}{*}{$\begin{array}{l}\text { An. č. } \\
\text { Minerál }\end{array}$} & mean & 1 & 2 & 3 & 4 & 5 & 6 & mean & 7 & 8 & 9 & 10 & 11 & 12 \\
\hline & \multicolumn{7}{|c|}{ tennantit-(Zn) } & \multicolumn{7}{|c|}{ tennantit-(Zn) až tetraedrit-(Zn) } \\
\hline$\overline{\mathrm{Ag}}$ & 0.19 & 0.17 & 0.13 & 0.21 & 0.12 & 0.09 & 0.49 & 0.76 & 0.54 & 0.54 & 0.77 & 0.93 & 0.91 & 0.94 \\
\hline$u$ & 40.93 & 41.47 & 41.05 & 41.29 & 41.09 & 40.83 & 40.00 & 38.55 & 39.72 & 39.13 & 38.58 & 37.81 & 38.13 & 37.79 \\
\hline e & 0.87 & 1.85 & 0.15 & 1.31 & 0.29 & 0.04 & 1.65 & 1.78 & 2.25 & 2.24 & 1.62 & 1.59 & 1.84 & 1.57 \\
\hline$n$ & .17 & 6.22 & 8.00 & 6.63 & 7.94 & 7.99 & 6.27 & 5.61 & 5.23 & 5.09 & 5.77 & 5.72 & 5.68 & 5.71 \\
\hline$d$ & 0.22 & 0.20 & 0.24 & 0.12 & 0.21 & 0.39 & 0.09 & 0.20 & 0.20 & 0.17 & 0.17 & 0.29 & 0.16 & 0.26 \\
\hline$s$ & 18.65 & 19.88 & 18.93 & 18.78 & 18.61 & 18.45 & 18.31 & 9.73 & 12.99 & 11.53 & 9.58 & 8.13 & 8.34 & 8.02 \\
\hline 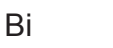 & .00 & 0.00 & 0.00 & 0.00 & 0.00 & 0.00 & 0.00 & 1.34 & 0.95 & 1.25 & 1.02 & 2.06 & 1.33 & 1.49 \\
\hline$b$ & 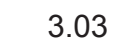 & 0.50 & 2.24 & 2.56 & 2.84 & 2.86 & 5.64 & 14.76 & 10.48 & 12.10 & 15.36 & 16.56 & .82 & 17.01 \\
\hline 0 & .86 & 28.42 & 27.97 & 27.89 & 27.87 & 27.71 & 27.67 & 26.06 & 26.79 & 26.40 & 26.06 & 25.61 & 25.83 & 25.78 \\
\hline Total & & 98.71 & 98 & 98. & & & & & 99 & & & 70 & 5 & 98.57 \\
\hline 9 & 27 & 0.023 & 0.018 & 0.029 & 0.017 & 0.012 & 0.069 & 0.113 & 0.079 & 0.080 & 0.115 & 0.141 & 0.136 & 0.143 \\
\hline$u$ & & 9.910 & 9.886 & & & & 84 & & 9.843 & & & 53 & 40 & 9.759 \\
\hline e & 0.238 & 0.503 & 0.041 & 0.358 & 0.079 & 0.011 & 0.449 & 0.515 & 0.635 & 0.642 & 0.468 & 0.467 & 0.534 & 0.461 \\
\hline$n$ & 1.676 & 1.446 & 1.873 & 1.546 & 1.855 & 1.881 & 1.460 & 1.387 & 1.260 & 1.247 & 1.424 & 1.426 & 1.411 & 1.43 \\
\hline $\mathrm{Cd}$ & 31 & 0.027 & 0.032 & 0.017 & 0.029 & 0.054 & 0.012 & & 0.028 & 0.024 & 0.024 & 0.043 & 0.024 & 0.03 \\
\hline As & 3.803 & 4.029 & 3.867 & 3.822 & 3.792 & 3.791 & 3.721 & 2.098 & 2.730 & 2.463 & 2.063 & 1.778 & 1.807 & 1.756 \\
\hline $\mathrm{Bi}$ & 000 & 0.000 & 0.000 & 0.000 & 0.000 & 0.000 & 0.000 & 0.103 & 0.071 & 0.096 & 0.079 & 0.162 & 0.104 & 0.117 \\
\hline $\mathrm{Sb}$ & 0.380 & 0.062 & 0.282 & 0.320 & 0.356 & 0.362 & 0.705 & 1.957 & 1.354 & 1.591 & 2.035 & 2.229 & 2.243 & 2.29 \\
\hline 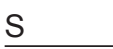 & 13.278 & 3.461 & 3.349 & 3.261 & 3270 & 13.370 & 3.139 & 3.127 & 13.156 & 3.178 & 13110 & 1309 & 13.077 & 13.19 \\
\hline
\end{tabular}

Tabulka 4 Chemické složení Bi bohatého tennantitu-(Zn) a tennantitu-(Fe) z Jedové jámy. Obsahy v hm. \%, hodnoty apfu jsou vypočitány na základ 16 atomů kovů a metaloidů na vzorcovou jednotku.

\begin{tabular}{|c|c|c|c|c|c|c|c|c|c|}
\hline $\begin{array}{l}\text { An. č. } \\
\text { Minerál }\end{array}$ & \multicolumn{4}{|c|}{ Bi-bohatý tennantit-(Zn) } & \multicolumn{5}{|c|}{ tennantit-(Fe) } \\
\hline $\mathrm{Ag}$ & 1.36 & 1.57 & 1.37 & 1.15 & 0.16 & 0.23 & 0.18 & 0.12 & 0.12 \\
\hline $\mathrm{Cu}$ & 35.54 & 33.71 & 36.04 & 36.87 & 41.09 & 40.09 & 40.52 & 41.69 & 42.07 \\
\hline $\mathrm{Fe}$ & 0.67 & 1.17 & 0.09 & 0.74 & 3.59 & 3.29 & 3.98 & 3.44 & 3.65 \\
\hline $\mathrm{Zn}$ & 6.27 & 5.91 & 6.67 & 6.23 & 2.52 & 2.59 & 2.17 & 2.93 & 2.38 \\
\hline $\mathrm{Cd}$ & 1.00 & 1.12 & 1.20 & 0.67 & 0.03 & 0.02 & 0.03 & 0.02 & 0.03 \\
\hline As & 9.71 & 8.94 & 9.47 & 10.71 & 15.18 & 13.41 & 13.84 & 16.22 & 17.23 \\
\hline $\mathrm{Bi}$ & 18.61 & 19.79 & 18.65 & 17.40 & 9.53 & 12.44 & 12.39 & 7.32 & 5.98 \\
\hline $\mathrm{Sb}$ & 0.95 & 1.27 & 1.02 & 0.57 & 0.37 & 0.83 & 0.02 & 0.27 & 0.37 \\
\hline$S$ & 24.16 & 23.27 & 24.48 & 24.74 & 26.64 & 26.17 & 26.17 & 26.95 & 27.27 \\
\hline Total & 98.27 & 96.73 & 98.99 & 99.08 & 99.11 & 99.06 & 99.30 & 98.96 & 99.10 \\
\hline $\mathrm{Ag}$ & 0.221 & 0.259 & 0.221 & 0.183 & 0.024 & 0.036 & 0.027 & 0.017 & 0.017 \\
\hline $\mathrm{Cu}$ & 9.775 & 9.529 & 9.883 & 9.914 & 10.319 & 10.334 & 10.312 & 10.317 & 10.315 \\
\hline $\mathrm{Fe}$ & 0.210 & 0.377 & 0.028 & 0.226 & 1.031 & 0.965 & 1.169 & 0.969 & 1.019 \\
\hline $\mathrm{Zn}$ & 1.677 & 1.624 & 1.778 & 1.628 & 0.613 & 0.644 & 0.537 & 0.704 & 0.567 \\
\hline $\mathrm{Cd}$ & 0.156 & 0.180 & 0.186 & 0.103 & 0.004 & 0.003 & 0.005 & 0.003 & 0.005 \\
\hline As & 2.263 & 2.143 & 2.203 & 2.442 & 3.227 & 2.932 & 2.987 & 3.404 & 3.584 \\
\hline $\mathrm{Bi}$ & 1.559 & 1.701 & 1.554 & 1.423 & 0.733 & 0.975 & 0.959 & 0.550 & 0.446 \\
\hline $\mathrm{Sb}$ & 0.137 & 0.187 & 0.144 & 0.080 & 0.037 & 0.062 & 0.003 & 0.034 & 0.047 \\
\hline S & 13.176 & 13.036 & 13.306 & 13.185 & 13.259 & 13.369 & 13.200 & 13.216 & 13.252 \\
\hline
\end{tabular}




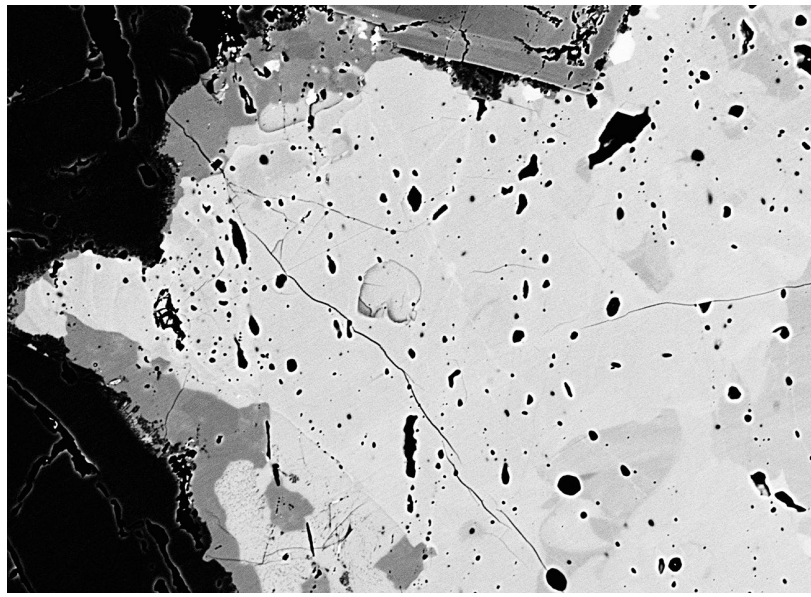

Obr. 19 Zonální velké zrno tennantit-tetraedritu bez Bi (hlavní hmota bělošedá s tmavšími izometrickými doménami bohatšími As), po obvodě lemované stanoiditem (tmavošedá) a kësteritem (nepatrně tmavěji šedá než hlavní hmota tennantit-tetraedritu) na kontaktu se sfaleritem (černá) a automorfním arsenopyritem (šedá v horní části snímku); Jedová jáma; šiřka záběru $420 \mu \mathrm{m}$, foto v BSE Z. Dolníček.

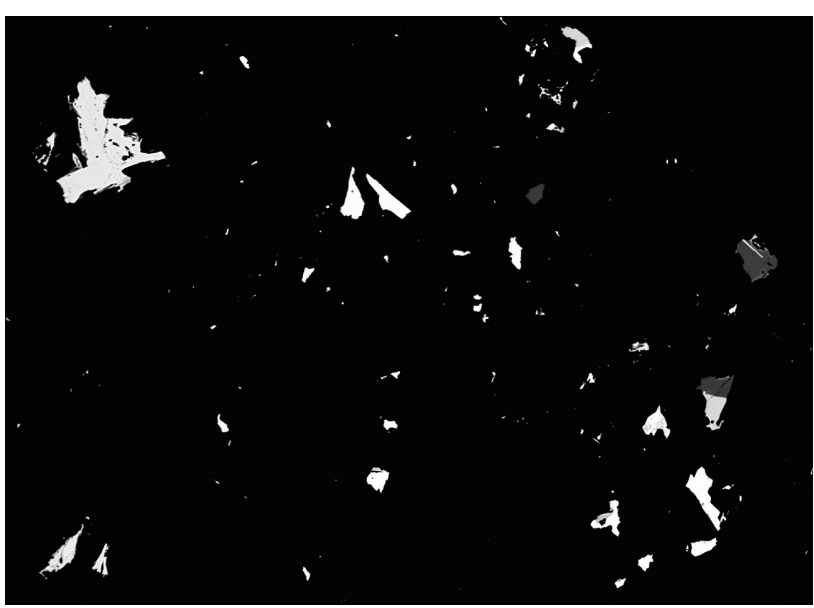

Obr. 20 Srůst jehličkovitých krystalů bismutinitu (bělošedé), zrna ryzího bismutu (bilá), wittichenitu (tmavě šedé) a aikinitu (středně šedá); Jedová jáma; šiřka záběru $700 \mu m$, foto v BSE Z. Dolníček.

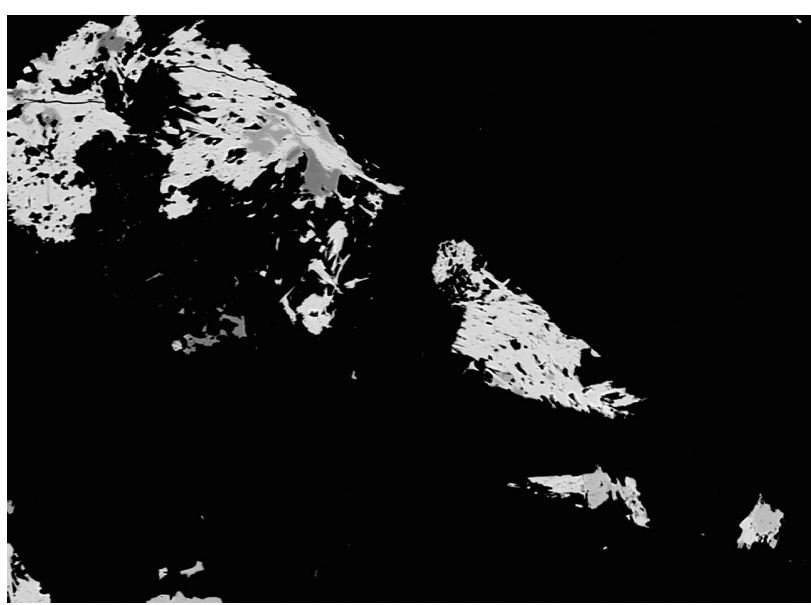

Obr. 21 Jehličkovité agregáty bismutinitu (světle šedý) se zrnem matilditu (tmavěji šedý) a zrny aikinitu (středně šedý); Jedová jáma; šíŕka záběru $490 \mu \mathrm{m}$, foto v BSE Z. Dolníček

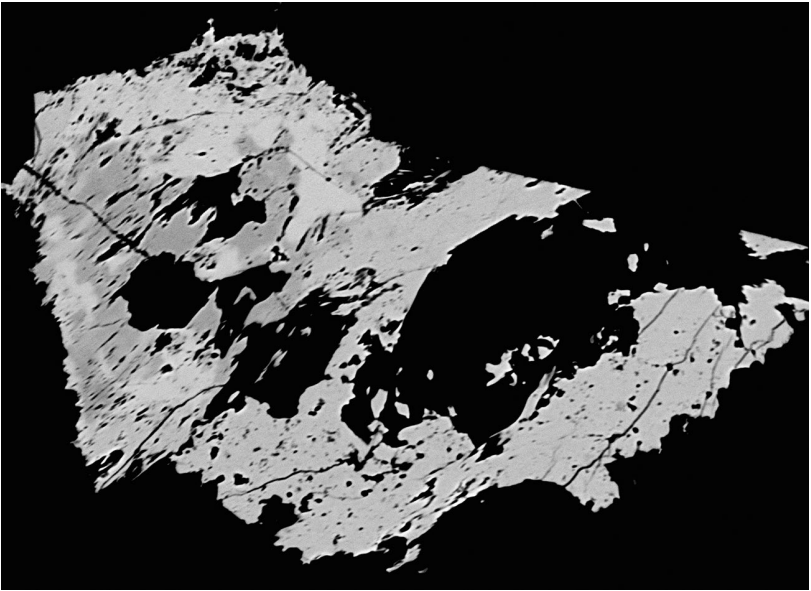

Obr. 22 Zrno bismutinitu (světle šedý) obrůstající tmavěji šedý hammarit; Jedová jáma; šírka záběru 300 m, foto v BSE Z. Dolníček.

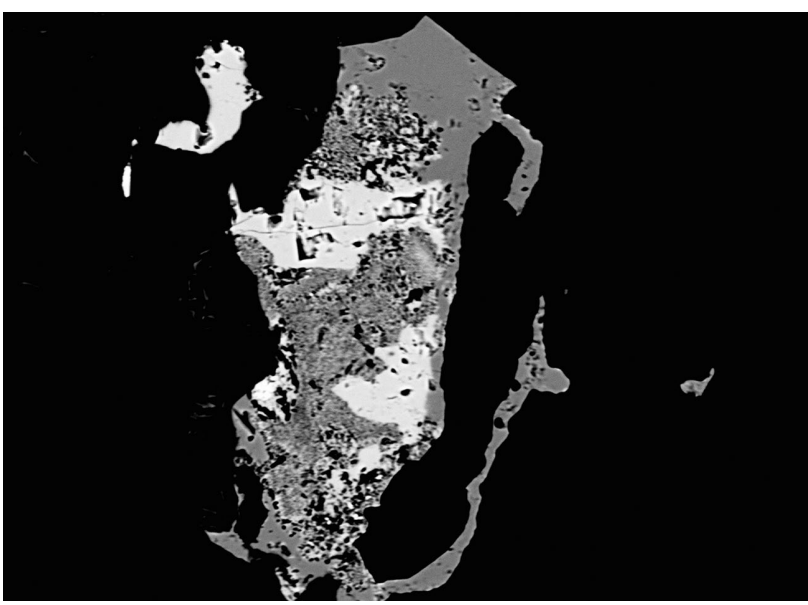

Obr. 23 Wittichenit (tmavošedý) srůstající s emplektitem (světle šedý); Jedová jáma; šiřka záběru $340 \mu \mathrm{m}$, foto v BSE Z. Dolníček.

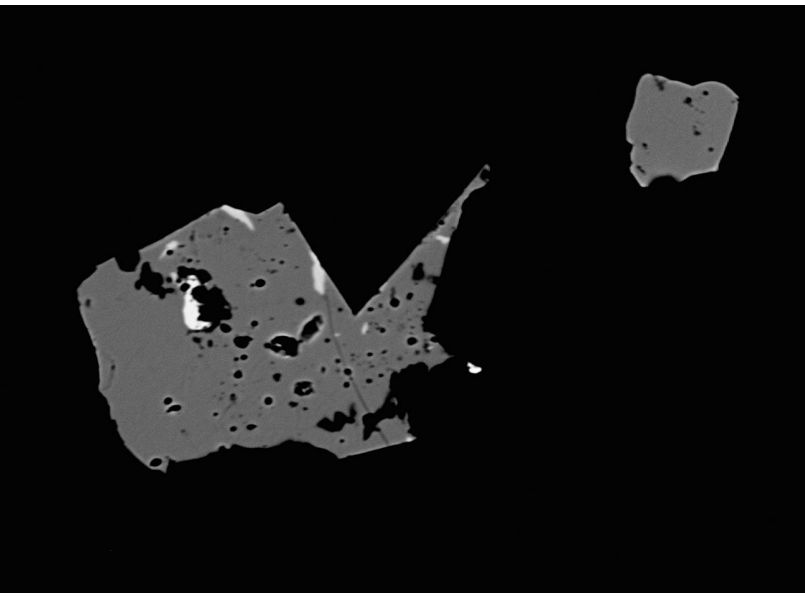

Obr. 24 Zrno wittichenitu (tmavošedý) s inkluzemi bohdanowitzitu (bělošedý); Jedová jáma; šiřka záběru 240 $\mu m$, foto v BSE Z. Dolníček. 
Převládajícím tetraedritem $v$ nábrusech je tetraedrit -(Zn) s nižšími až středně vysokými obsahy Bi, který tvoří až $1 \mathrm{~mm}$ velká, xenomorfně omezená zrna, která někdy srůstají s tetraedritem s vysokým podílem Bi. Něk- dy srůstá s matilditem (obr. 14). Při studiu chemického složení tetraedritu-(Zn) (tab. 2) bylo zjištěno, že jeho složení značně kolísá. V BSE obraze mají zrna tetraedritu v některých případech zonální stavbu. Vedle Cu a Sb byly

Tabulka 5 Chemické složení bismutinitu (Bmt) a emplektitu (Emp) z Jedové jámy. Obsahy v hm. \%, hodnoty apfu jsou vypočitány na základ pěti (bismutinit), respektive čtyř (emplektit) atomů na vzorcovou jednotku.

\begin{tabular}{|c|c|c|c|c|c|c|c|c|c|c|c|c|c|c|}
\hline An. č. & mean & 1 & 2 & 3 & 4 & 5 & 6 & mean & 7 & 8 & 9 & 10 & 11 & 12 \\
\hline Minerál & Bmt & $\mathrm{Bmt}$ & Bmt & $\mathrm{Bmt}$ & $\mathrm{Bmt}$ & Bmt & Bmt & Emp & Emp & Emp & Emp & Emp & Emp & Emp \\
\hline$\overline{\mathrm{Pb}}$ & 1.06 & 1.61 & 0.19 & 0.12 & 1.87 & 2.25 & 0.30 & 0.00 & 0.00 & 0.00 & 0.00 & 0.00 & 0.00 & 0.00 \\
\hline $\mathrm{Cu}$ & 0.32 & 0.47 & 0.08 & 0.03 & 0.57 & 0.71 & 0.08 & 18.98 & 18.92 & 18.74 & 20.28 & 19.06 & 18.62 & 18.59 \\
\hline $\mathrm{b}$ & 14 & 0.07 & 0.11 & 0.18 & 0.14 & 0.19 & 0.16 & 0.00 & 0.00 & 0.00 & 0.00 & 0.00 & 0.00 & 0.00 \\
\hline$B i$ & 78.65 & 77.85 & 79.43 & 79.68 & 78.03 & 77.51 & 79.41 & 61.41 & 61.00 & 61.70 & 61.54 & 60.75 & 61.54 & 61.20 \\
\hline$S$ & .04 & 18.93 & 18.84 & 19.13 & 19.11 & 19.20 & 19.00 & 19.48 & 19.33 & 19.29 & 19.49 & 19.58 & 19.27 & 19.25 \\
\hline $\mathrm{Se}$ & 08 & .21 & 0.12 & 0.00 & 0.11 & 0.01 & 0.04 & 0.00 & 0.00 & 0.00 & 0.00 & 0.00 & 0.00 & 0.00 \\
\hline Total & 29 & 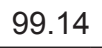 & 7 & & 3 & 37 & & 37 & 25 & .73 & 31 & 39 & 9.43 & 9.05 \\
\hline $\mathrm{b}$ & 026 & 0.040 & 0.005 & 03 & 0.046 & 055 & 007 & 0.000 & 0.000 & 0.000 & 0.000 & 0.000 & 0.000 & 0.000 \\
\hline $\mathrm{u}$ & 26 & 8 & .006 & & 0.045 & 56 & 066 & 96 & 99 & 90 & & 99 & 886 & .987 \\
\hline $\mathrm{Sb}$ & 006 & 0.003 & 0.005 & 0.008 & 0.006 & 0.008 & 0.007 & 0.000 & 0.000 & 0.000 & 0.000 & 0.000 & 0.000 & 0.00 \\
\hline $\mathrm{Bi}$ & 1.915 & 1.898 & 1.955 & 1.944 & 1.886 & 1.867 & 1.944 & 0.979 & 0.979 & 0.991 & 0.969 & 0.968 & 0.991 & 0.98 \\
\hline$S$ & 022 & 3.008 & 3.021 & 3.042 & 3.010 & 3.014 & 3.032 & 2.025 & 2.022 & 2.019 & 1.991 & 2.033 & 2.023 & 2.02 \\
\hline $\mathrm{Se}$ & 0.005 & 0.014 & 0.008 & 0.000 & 0.007 & 0.001 & 0.003 & 0.000 & 0.000 & 0.000 & 0.000 & 0.000 & 0.000 & 0.00 \\
\hline
\end{tabular}

Tabulka 6 Chemické složení matilditu (Mat) a aikinitu (Aik) z Jedové jámy. Obsahy v hm. \%, hodnoty apfu jsou vypočítány na základ čtyř (matildit), respektive šesti (aikinit) atomů na vzorcovou jednotku.

\begin{tabular}{|c|c|c|c|c|c|c|c|c|c|c|c|c|c|c|}
\hline An. č. & mean & 1 & 2 & 3 & 4 & 5 & 6 & mean & 7 & 8 & 9 & 10 & 11 & 12 \\
\hline Minerál & Mat & Mat & Mat & Mat & Mat & Mat & Mat & Aik & Aik & Aik & Aik & Aik & Aik & Aik \\
\hline $\mathrm{Ag}$ & 27.52 & 27.45 & 27.17 & 27.06 & 27.62 & 27.96 & 27.78 & 0.00 & 0.00 & 0.00 & 0.00 & 0.00 & 0.00 & 0.00 \\
\hline $\mathrm{Cu}$ & 0.71 & 1.61 & 1.09 & 0.28 & 0.59 & 0.82 & 0.25 & 11.15 & 10.86 & 10.62 & 10.58 & 11.78 & 11.70 & 11.36 \\
\hline $\mathrm{Pb}$ & 00 & 0.00 & 0.00 & 0.00 & 0.00 & 0.00 & 0.00 & & 34.86 & 34.36 & 35.47 & 34.51 & .50 & 34.37 \\
\hline $\mathrm{Fe}$ & 0.26 & 0.69 & 0.38 & 0.00 & 0.27 & 0.36 & 0.04 & 0.34 & 0.45 & 0.45 & 0.84 & 0.00 & 0.02 & 0.01 \\
\hline $\mathrm{Bi}$ & 2.04 & 51.66 & 52.01 & 52.21 & 51.92 & 52.92 & 52.34 & 31 & 38.23 & 38.55 & 37.72 & 37.95 & 38.15 & 38.66 \\
\hline S & .85 & 16.96 & 16.76 & 16.64 & 16.71 & 16.97 & 16.97 & 17.10 & 17.11 & 16.96 & 16.94 & 17.13 & 17.21 & 17.12 \\
\hline Total & 38 & 98.37 & 41 & 19 & 11 & 03 & 38 & & 51 & 94 & 10 & .37 & 58 & 52 \\
\hline $\mathrm{Ag}$ & 976 & 0.953 & 0.962 & 0.980 & 0.985 & 0.982 & 0.989 & 00 & 0.000 & 0.000 & 0.000 & 0.000 & 0.000 & 0.000 \\
\hline $\mathrm{Cu}$ & 043 & 0.095 & 0.065 & 0.017 & 0.036 & 0.049 & 0.015 & 88 & 0.964 & 51 & 41 & 42 & 032 & .008 \\
\hline $\mathrm{Pb}$ & 0.000 & 0.000 & 0.000 & 0.000 & 0.000 & 0.000 & 0.000 & 44 & 0.949 & 0.944 & 0.968 & .936 & 0.933 & 0.93 \\
\hline $\mathrm{Fe}$ & 018 & 0.046 & 0.026 & 0.000 & 0.019 & 0.024 & 0.003 & & 0.045 & 46 & 0.085 & 0.000 & 0.002 & 0.00 \\
\hline I & 953 & 0.926 & 0.950 & 0.976 & 0.956 & 0.941 & 0.952 & & 1.032 & 1.050 & 1.020 & 1.020 & 1.023 & 1.04 \\
\hline 0 & 2.011 & 1.980 & 1.996 & 2.027 & 2.005 & 2.004 & 2.030 & 3.002 & 3.010 & 3.010 & 2.986 & 3.002 & 3.009 & 3.01 \\
\hline
\end{tabular}

Tabulka 7 Chemické složení hammaritu (Ham) a bohdanowitzitu (Boh) z Jedové jámy. Obsahy v hm. \%, hodnoty apfu jsou vypočitány na základ 17 (hammarit), respektive čtyř (bohdanowitzit) atomů na vzorcovou jednotku.

\begin{tabular}{lrrrrrrrrrrrr}
\hline An. Č. & mean & 1 & 2 & 3 & 4 & mean & 5 & 6 & 7 & 8 & 9 & 10 \\
Minerál & Ham & Ham & Ham & Ham & Ham & Boh & Boh & Boh & Boh & Boh & Boh & Boh \\
\hline $\mathrm{Ag}$ & 0.00 & 0.00 & 0.00 & 0.00 & 0.00 & 22.25 & 22.41 & 22.71 & 20.89 & 21.91 & 22.70 & 22.88 \\
$\mathrm{Cu}$ & 7.69 & 7.87 & 8.21 & 7.01 & 7.49 & 2.33 & 3.12 & 2.05 & 2.68 & 1.72 & 1.79 & 2.64 \\
$\mathrm{Zn}$ & 0.00 & 0.00 & 0.00 & 0.00 & 0.00 & 0.22 & 0.22 & 0.27 & 0.38 & 0.04 & 0.06 & 0.35 \\
$\mathrm{~Pb}$ & 26.18 & 28.75 & 27.23 & 23.85 & 24.89 & 0.00 & 0.00 & 0.00 & 0.00 & 0.00 & 0.00 & 0.00 \\
$\mathrm{Bi}$ & 48.66 & 45.32 & 47.32 & 51.96 & 50.04 & 44.24 & 43.93 & 44.74 & 42.58 & 45.88 & 43.71 & 44.58 \\
$\mathrm{~S}$ & 17.40 & 17.02 & 17.55 & 17.59 & 17.42 & 1.42 & 1.30 & 1.59 & 2.16 & 1.39 & 1.22 & 0.86 \\
$\mathrm{Se}$ & 0.00 & 0.00 & 0.00 & 0.00 & 0.00 & 30.67 & 31.82 & 30.10 & 28.76 & 30.39 & 31.47 & 31.50 \\
\hline Total & 99.89 & 98.96 & 100.31 & 100.40 & 99.84 & 101.13 & 102.80 & 101.46 & 97.45 & 101.33 & 100.95 & 102.81 \\
$\mathrm{Ag}$ & 0.000 & 0.000 & 0.000 & 0.000 & 0.000 & 0.936 & 0.909 & 0.949 & 0.883 & 0.925 & 0.951 & 0.945 \\
$\mathrm{Cu}$ & 2.002 & 2.084 & 2.123 & 1.884 & 1.963 & 0.135 & 0.215 & 0.145 & 0.192 & 0.123 & 0.127 & 0.185 \\
$\mathrm{Zn}$ & 0.000 & 0.000 & 0.000 & 0.000 & 0.000 & 0.015 & 0.015 & 0.019 & 0.029 & 0.003 & 0.004 & 0.024 \\
$\mathrm{~Pb}$ & 2.101 & 2.335 & 2.160 & 1.914 & 2.001 & 0.000 & 0.000 & 0.000 & 0.000 & 0.000 & 0.000 & 0.000 \\
$\mathrm{Bi}$ & 3.872 & 3.649 & 3.721 & 4.133 & 3.988 & 0.951 & 0.920 & 0.960 & 0.929 & 0.999 & 0.945 & 0.950 \\
$\mathrm{~S}$ & 9.024 & 8.932 & 8.995 & 9.120 & 9.048 & 0.199 & 0.177 & 0.222 & 0.307 & 0.197 & 0.172 & 0.119 \\
$\mathrm{Se}$ & 0.000 & 0.000 & 0.000 & 0.000 & 0.000 & 1.744 & 1.764 & 1.710 & 1.661 & 1.752 & 1.801 & 1.777 \\
\hline
\end{tabular}


zjištěny vysoké obsahy Zn (1.560 - 1.816 apfu), méně je As (0.667 - 1.187 apfu), Bi (0.120 - 0.771 apfu) a menší příměsi Ag (0.153 - 0.308 apfu) a Fe (0.140 - 0.359 apfu). Průměrný (sedm bodových analýz) empirický vzorec tohoto tetraedritu-( $Z n)$ z Jedové jámy je možno na bázi 16 atomů kovů a metaloidů vyjádřit jako $\left(\mathrm{Cu}_{5.79} \mathrm{Ag}_{0.21}\right)_{\Sigma 6.00}$ $\left(\mathrm{Cu}_{3.91} \mathrm{Zn}_{1.73} \mathrm{Fe}_{0.24}\right)_{\Sigma 5.88}\left(\mathrm{Sb}_{2.62} \mathrm{As}_{1.07} \mathrm{Bi}_{0.42}\right)_{\Sigma 4.11} \mathrm{~S}_{13.12}$.

Některá zrna tetraedritu-(Zn) jsou vroubena či pronikána až $50 \mu \mathrm{m}$ silnými lemy, respektive žilkami Bi bohatého tetraedritu-(Zn) (tab. 2), jinde tvoří samostatná zrna zarůstající do křemenné či fluoritové žiloviny. Jeho partie bývají v BSE obraze výrazně zonální (od centra k okraji vzrůstá obsah $\mathrm{Bi}$ ). Vedle $\mathrm{Cu}$ a Sb byly zjištěny vysoké obsahy Zn (1.729 - 1.776 apfu), As (0.825 - 1.121 apfu) a $\mathrm{Bi}(0.794-1.108$ apfu) a menší príměsi $\mathrm{Ag}(0.215$ - 0.302 apfu), Fe (0.127 - 0.204 apfu) a In (0.007 - 0.023 apfu). Průměrný (šest bodových analýz) empirický vzorec tohoto $\mathrm{Bi}$ bohatého tetraedritu-(Zn) z Jedové jámy je možno na bázi 16 atomů kovů a metaloidů vyjádřit jako $\left(\mathrm{Cu}_{5.73} \mathrm{Ag}_{0.27}\right)_{\Sigma 6.00}\left(\mathrm{Cu}_{3.94} \mathrm{Zn}_{1.75} \mathrm{Fe}_{0.19} \mathrm{In}_{0.02}\right)_{\Sigma 5.90}\left(\mathrm{Sb}_{2.19} \mathrm{As}_{0.99}\right.$ $\left.\mathrm{Bi}_{0.93}\right)_{\Sigma 4.11} \mathrm{~S}_{13.43}$. Obdobně Bi bohaté tetraedrity-(Zn) byly zjištěny v Jáchymově (Velebil, Sejkora 2018).

$S$ tetraedritem- $(Z n)$, prrípadně $s$ Bi bohatým tetraedritem-(Zn), srůstá tennantit-(Zn), který tvoří až $0.1 \mathrm{~mm}$ velká nepravidelná zrna. Tennantit-(Zn) (tab. 3) charakterizuje vysoký obsah Zn (1.455 - 1.885 apfu), absence $\mathrm{Bi}$, poměrně nízké, kolísavé obsahy Sb (0.062 - $0.705 a p f u)$ a Fe (0.011 - $0.503 \mathrm{apfu})$. Vedle toho jsou v tomto tennantitu prrítomny malé príměsi $\mathrm{Ag}(0.011-0.069 \mathrm{apfu})$ a $\mathrm{Cd}$ (0.012 - 0.054 apfu). Průměrný (osm bodových analýz) empirický vzorec tohoto tennantitu-(Zn) z Jedové jámy je možno na bázi 16 atomů kovů a metaloidů vyjádřit jako $\left(\mathrm{Cu}_{5.97} \mathrm{Ag}_{0.03}\right)_{\Sigma 6.00}\left(\mathrm{Cu}_{3.87} \mathrm{Zn}_{1.68} \mathrm{Fe}_{0.24} \mathrm{Cd}_{0.03}\right)_{\Sigma 5.82}\left(\mathrm{As}_{3.80} \mathrm{Sb}_{0.38}\right)_{\Sigma 4.18}$ $\mathrm{S}_{13.28}$. Značnou část tetraedritových $\mathrm{zrn}$ studovaných nábrusů tvoři tetraedrity se složením na rozhraní tetraedritu-(Zn) a tennantitu-(Zn) (tab. 3). Tvoří až $1 \mathrm{~mm}$

Tabulka 8 Chemické složení wittichenitu (Wit) a bournonitu (Bnn) z Jedové jámy. Obsahy v hm. \%, hodnoty apfu jsou vypočítány na základ sedmi (wittichenit), respektive šesti (bournonit) atomů na vzorcovou jednotku.

\begin{tabular}{|c|c|c|c|c|c|c|c|c|c|c|c|c|c|c|}
\hline An. č. & nean & 1 & 2 & 3 & 4 & 5 & 6 & mean & 7 & 8 & 9 & 10 & 11 & \\
\hline Minerál & Wit & Wit & Wit & Wit & Wit & Wit & Wit & Bnn & Bnn & Bnn & Bnn & & Bnn & 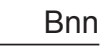 \\
\hline 9 & 0.42 & 0.42 & 0.37 & 0.48 & 0.57 & 0.41 & 0.33 & & 0.00 & 0.00 & 0.00 & 0 & & 8 \\
\hline $\mathrm{u}$ & & & & & & & & & & & & & & \\
\hline - & & 0.00 & 0.00 & 0.00 & 0.00 & 0.00 & 0.00 & & 0.83 & 1.03 & 1.06 & & 1.83 & \\
\hline 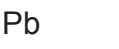 & & 0.00 & 0 & 0.00 & 0.00 & 0.00 & 0.00 & 41 & 41.73 & 41 & 37 & 3 & 8 & 2.2 \\
\hline & & & & & & & & & & & & & & 8.5 \\
\hline & & 0 & 0 & 0 & 0 & 0.00 & 0.00 & & & & & & & 4.7 \\
\hline & & 40.77 & & & & & 43.63 & & 0.00 & 0 . & 0 & 0 & 0 & 0.0 \\
\hline$\varsigma$ & & & & & & & & & & & & & & 04 \\
\hline se & 2 & 15 & 08 & 6 & 12 & 17 & 06 & 0 & 0.00 & 0.00 & 0.00 & 0.00 & 0.00 & 0.0 \\
\hline Total & 13 & 8.13 & 8.85 & 97.81 & 99.03 & 98.66 & 99.83 & 99.50 & 99.61 & 9.60 & 7.65 & 99.31 & 0.81 & 0.1 \\
\hline$g$ & & & & & & & & & & & & & & $\mathrm{O}$ \\
\hline u & & & & & & & & & & & & & & 9 \\
\hline & & & & & & & & & & & & & & 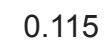 \\
\hline $\mathrm{Pb}$ & & 00 & 00 & 00 & 00 & 00 & 00 & 8 & 5 & 54 & 54 & & & .95 \\
\hline $\mathrm{Sb}$ & & & & & & & & & & & & & & .71 \\
\hline & & & & & & & & & & & & & & 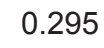 \\
\hline $\mathrm{Bi}$ & & 0.978 & & & & & & & & 0 & & & & .00 \\
\hline$S$ & & 3.049 & 3.009 & 3.042 & 3.045 & 3.020 & 3.017 & & & & & & & 2.98 \\
\hline Se & 0.008 & 0.010 & 0.005 & 0.010 & 0.008 & 0.011 & 0.004 & 0.000 & 0.000 & 0.000 & 0.000 & 0.000 & 0.000 & 0.00 \\
\hline
\end{tabular}

Tabulka 9 Chemické složení kësteritu (Kes) a stanoiditu (Std) z Jedové jámy. Obsahy v hm. \%, hodnoty apfu jsou vypočitány na základ čtyř (kësterit), respektive 12 (stanoidit) atomů S.

\begin{tabular}{|c|c|c|c|c|c|c|c|c|c|c|c|c|c|c|}
\hline An. č. & mean & 1 & 2 & 3 & 4 & 5 & 6 & mean & 7 & 8 & 9 & 10 & 11 & \\
\hline Minerál & Kes & Kes & Kes & Kes & Kes & Kes & Kes & Std & Std & Std & Std & Std & Std & \\
\hline$\overline{\mathrm{Cu}}$ & 8.14 & 8.11 & 8.80 & 8.78 & 29.15 & 28.49 & 28.64 & 7.11 & 7.14 & 7.16 & 7.34 & 7.03 & 6.98 & 7. \\
\hline $\mathrm{Cd}$ & 22 & 23 & .21 & 0.27 & 0.19 & 0.20 & 0.22 & 0.08 & 19 & 0.05 & 0.06 & 0.07 & 0.07 & \\
\hline In & & & & & & & 12 & & & & 00 & .00 & .00 & $\Omega$ \\
\hline$n$ & 26 & 4.00 & 12.16 & 12.06 & 11.77 & 11.93 & 11.87 & 4.53 & 5.01 & 4.47 & 4.25 & 4.58 & .38 & 4.5 \\
\hline e & & 73 & 68 & 2.10 & 2.22 & 1.91 & 2.05 & 8.59 & 8.49 & 8.67 & 8.99 & .50 & .37 & 8.4 \\
\hline & & 50 & 11 & .21 & 27.13 & 40 & 54 & & & 12 & 05 & 66 & 39 & 19.0 \\
\hline$\underline{S}$ & 86 & .19 & 9.34 & 6.91 & 29.18 & 29.00 & 28.91 & 29.21 & 29.23 & 29.09 & .22 & 9.15 & 9.20 & 29. \\
\hline otal & .96 & 9.88 & 98.42 & 97.44 & 99.79 & 99.06 & 99.35 & 98.51 & 99.37 & 98.56 & 98.91 & 97.92 & 97.39 & 98.8 \\
\hline $\mathrm{Cu}$ & & 44 & 31 & 8 & 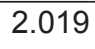 & & & 2 & 93 & 4 & 38 & 92 & 68 & 5 \\
\hline $\mathrm{Cd}$ & & 10 & 8 & 11 & 08 & 08 & 08 & 09 & 22 & 05 & 07 & 08 & 08 & on \\
\hline In & 05 & 0.004 & 0.004 & 0.005 & 0.006 & 0.008 & 0.004 & 0.000 & 0.000 & 0.000 & 0.000 & 0.000 & 0.000 & 0.0 \\
\hline 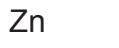 & & 0.941 & 813 & & & & & & & & 0.856 & .925 & 0.883 & \\
\hline $\mathrm{Fe}$ & & 0.136 & 0.132 & 0.179 & 0.175 & 0.151 & 0.163 & 2.026 & 2.001 & 2.053 & 2.120 & 2.009 & 1.975 & \\
\hline $\mathrm{Sn}_{n}$ & 989 & 0.981 & 0.962 & 1.092 & 1.006 & 1.026 & 1.029 & 2.107 & 2.142 & 2.131 & 2.113 & 2.075 & 2.041 & 0 \\
\hline$S$ & 4 & 4 & 4 & 4 & 4 & 4 & 4 & 12 & 12 & 12 & 12 & 12 & 12 & \\
\hline
\end{tabular}




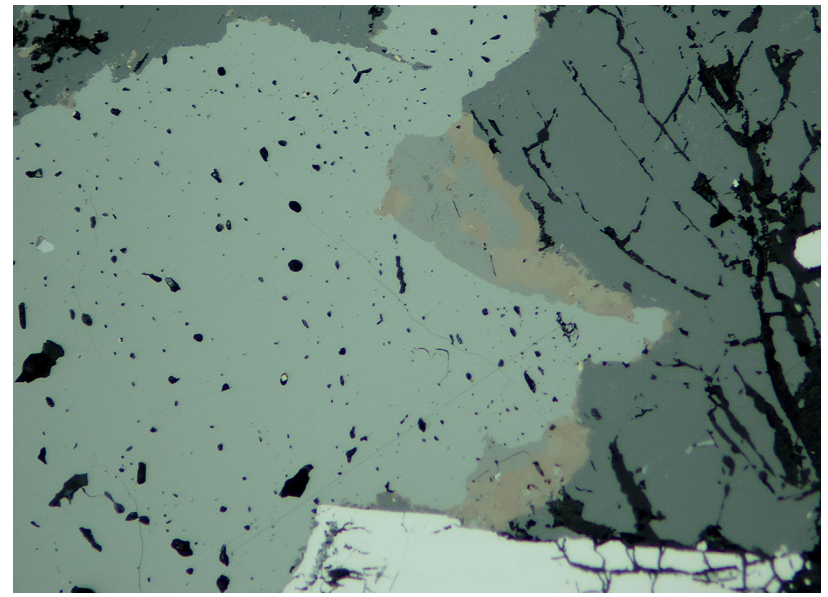

Obr. 25 Srůsty stanoiditu (hnědý se zřetelným dvojodrazem) a kësteritu (tmavě šedý) při hranici minerálu z tetraedritové skupiny (světle šedý) a sfaleritu (nejtmavši šedý). Bílý - arsenopyrit. Šiřka záběru $0.9 \mathrm{~mm}$. Nábrus, odražené světlo, foto Z. Dolníček.

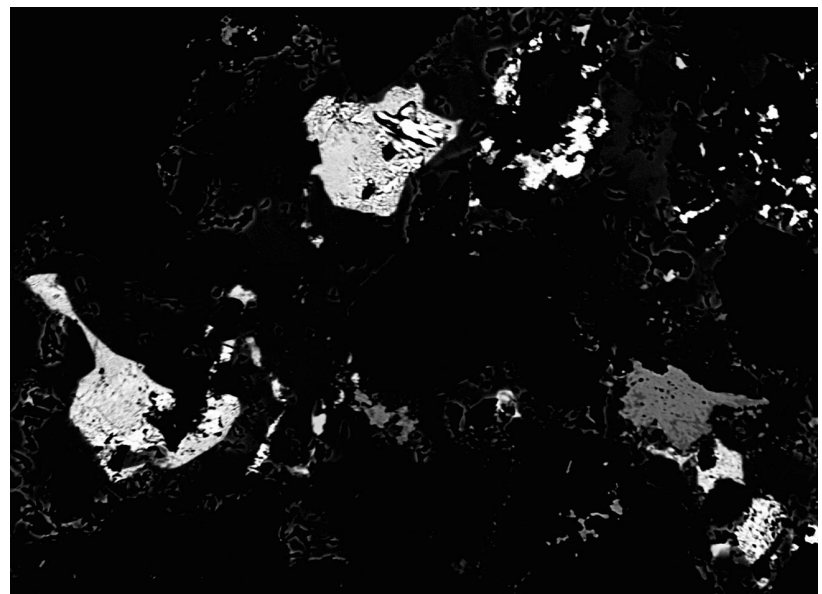

Obr. 26 Dvě zrna nepojmenovaného Bi-Cu-Fe sulfidu (šedá) s ryzím bismutem (světle šedá) a kasiteritem (tmavošedá); Jedová jáma; šírka záběru 350 m, foto v BSE Z. Dolníček.

Tabulka 10 Chemické složení nepojmenovaného nového Bi-Cu-Fe sulfidu z Jedové jámy. Obsahy v hm. \%, hodnoty apfu jsou vypočitány na základ šesti atomů na vzorcovou jednotku.

\begin{tabular}{lrrrrrrr}
\hline & mean & 1 & 2 & 3 & 4 & 5 & 6 \\
\hline $\mathrm{Ag}$ & 0.11 & 0.12 & 0.11 & 0.12 & 0.14 & 0.10 & 0.04 \\
$\mathrm{Cu}$ & 21.89 & 21.54 & 21.83 & 21.60 & 21.65 & 21.60 & 22.43 \\
$\mathrm{Fe}$ & 6.44 & 6.24 & 6.57 & 6.12 & 6.32 & 6.02 & 7.03 \\
$\mathrm{Bi}$ & 46.58 & 46.69 & 46.48 & 47.12 & 46.33 & 47.32 & 45.83 \\
$\mathrm{Sb}$ & 0.22 & 0.21 & 0.19 & 0.22 & 0.35 & 0.36 & 0.17 \\
$\mathrm{~S}$ & 22.53 & 22.38 & 22.60 & 22.38 & 22.54 & 22.27 & 22.73 \\
$\mathrm{Se}$ & 0.26 & 0.33 & 0.36 & 0.39 & 0.38 & 0.37 & 0.00 \\
\hline $\mathrm{Total}$ & 98.03 & 97.51 & 98.14 & 97.95 & 97.71 & 98.04 & 98.23 \\
$\mathrm{Ag}$ & 0.004 & 0.005 & 0.004 & 0.005 & 0.006 & 0.004 & 0.002 \\
$\mathrm{Cu}$ & 1.485 & 1.475 & 1.477 & 1.477 & 1.473 & 1.481 & 1.503 \\
$\mathrm{Fe}$ & 0.497 & 0.486 & 0.506 & 0.476 & 0.489 & 0.470 & 0.534 \\
$\mathrm{Bi}$ & 0.961 & 0.972 & 0.956 & 0.980 & 0.959 & 0.986 & 0.934 \\
$\mathrm{Sb}$ & 0.008 & 0.008 & 0.007 & 0.008 & 0.012 & 0.013 & 0.006 \\
$\mathrm{~S}$ & 3.030 & 3.037 & 3.030 & 3.033 & 3.040 & 3.026 & 3.019 \\
$\mathrm{Se}$ & 0.014 & 0.018 & 0.020 & 0.021 & 0.021 & 0.020 & 0.000 \\
\hline & & & & & & &
\end{tabular}

velká nepravidelně omezená, někdy laločnatá výrazně zonální zrna (obr. 12, 16, 17, 19), která srůstají s tennantitem- $(Z n), B i$ bohatým tetraedritem-(Zn) i tennantitem -(Zn), někdy i s arsenopyritem a kësteritem. Poměry Sb/ $(\mathrm{Sb}+\mathrm{As})$ se pohybuji v rozsahu $0.33-0.57$, průměr sedmi bodových stanovení je 0.48 (tedy mírně ve prospěch tennantitu). Tyto tetraedrity charakterizuje poměrně vysoký obsah Zn (1.247 - 1.497 apfu), nižší zastoupení Fe (0.339 - 0.642 apfu) a nízké obsahy Bi (0.071 - 0.162 apfu), Ag (0.079 - $0.143 a p f u)$ a Cd (0.024 - 0.043 apfu). Průměrný (sedm bodových analýz) empirický vzorec tohoto tetraedrit/tennantitu z Jedové jámy je možno na bázi 16 atomů kovů a metaloidů vyjádřit jako $\left(\mathrm{Cu}_{5.89} \mathrm{Ag}_{0.11}\right)_{\Sigma 6.00}\left(\mathrm{Cu}_{3.91} \mathrm{Zn}_{1.39}\right.$ $\left.\mathrm{Fe}_{0.52} \mathrm{Cd}_{0.03}\right)_{\Sigma 5.85}\left(\mathrm{As}_{2.10} \mathrm{Sb}_{1.96} \mathrm{Bi}_{0.10}\right)_{\Sigma 4.16} \mathrm{~S}_{13.13}$.

Poměrně malé zastoupení mezi studovanými minerály tetraedritové skupiny mají tennantity-(Zn) i -(Fe) s vysokým obsahem Bi (tab. 4). Tvoří nepravidelná zrna o rozměrech do $100 \mu \mathrm{m}$, která jsou někdy obrůstaná tennantitem-(Zn) (bez přítomnosti Bi), či vytvárí zonální srůsty $s$ tetraedrit-tennantity s malým obsahem Bi (do $2 \%$ ) (obr. 12). Maximální obsahy Bi byly zjištěny $v$ tennantitu-( $\mathrm{Zn})$ (tab. 8) (1.423 - 1.701 apfu), menší pak v tennantitu-(Fe) (0.446 - 0.975 apfu). Obdobně vysoké koncentrace Bi byly zjištěny i u tennantitu-(Zn) z Jáchymova (Velebil, Sejkora 2018). Tennantit-(Fe) charakterizuje velmi nízký obsah tetraedritové složky, obsahy Sb se pohybují v rozmezí 0.003 - 0.062 apfu. Tennantit-(Zn) obsahuje vedle toho i malou príměs $\mathrm{Ag}(0.183-0.259 \mathrm{apfu})$, Fe (0.228 - 0.377 apfu), Sb (0.080 - 0.187 apfu) a Cd (0.103 - 0.187 $a p f u$ ). Průměrný (tři bodové analýzy) empirický vzorec tohoto tennantitu-( $Z n)$ z Jedové jámy je možno na bázi 16 atomů kovů a metaloidů vyjádřit jako $\left(\mathrm{Cu}_{5.78} \mathrm{Ag}_{0.22}\right)_{\Sigma 6.00}$ $\left(\mathrm{Cu}_{4.00} \mathrm{Zn}_{1.68} \mathrm{Fe}_{0.21} \mathrm{Cd}_{0.16}\right)_{\Sigma 6.05}\left(\mathrm{As}_{2.26} \mathrm{Bi}_{1.56} \mathrm{Sb}_{0.14}\right)_{\Sigma 3.96} \mathrm{~S}_{13.18}$. Oproti tomu tennantit-(Fe) $z$ této asociace obsahuje jen nepatrné obsahy Ag (0.017 - 0.036 apfu) i Cd (0.003- 0.005 $a p f u$ ). Průměrný (čtyři bodové analýzy) empirický vzorec tohoto tennantitu-(Fe) z Jedové jámy je možno na bázi 16 atomů kovů a metaloidů vyjádřit jako $\left(\mathrm{Cu}_{5.98} \mathrm{Ag}_{0.02}\right)_{\Sigma 6.00}$ $\left(\mathrm{Cu}_{4.34} \mathrm{Fe}_{1.03} \mathrm{Zn}_{0.61}\right)_{\Sigma 5.98}\left(\mathrm{As}_{3.23} \mathrm{Bi}_{0.73} \mathrm{Sb}_{0.04}\right)_{\Sigma 4.00} \mathrm{~S}_{13.26}$.

Dalším Bi sulfidem, který se na lokalitě vyskytuje i v makroskopických ukázkách, je bismutinit. Tvoří v drobných dutinách až několik $\mathrm{mm}$ dlouhé, kovově šedé jehličkovité krystaly, v nábrusech je automorfně jehlicovitý (délka jehlic do $250 \mu \mathrm{m}$ ) (obr. 20) či tvoří nepravidelná zrna 100 - $150 \mu \mathrm{m}$ velká. Vyskytuje se $v$ žilovině samostatně či srůstá $s$ emplektitem o rozměrech do $10 \mu \mathrm{m}$. $\checkmark$ několika případech $v$ jeho hmotě zarůstají až $20 \mu \mathrm{m}$ velká zrna matilditu, aikinitu (obr. 21) či hammaritu (obr. 22). Při studiu jeho chemického složení (tab. 5) byly vedle $\mathrm{Bi}$ a S zjištěny minoritní příměsi $\mathrm{Cu}$ (0.002 - 0.056 apfu), $\mathrm{Pb}$ (0.003 - 0.055 apfu), Sb (0.003 - 0.008 apfu) a Se (0 0.014 apfu). Průměrný (šest bodových analýz) empirický vzorec bismutinitu z Jedové jámy je možno na bázi 5 apfu vyjádřit jako $\left(\mathrm{Bi}_{1.91} \mathrm{Cu}_{0.03} \mathrm{~Pb}_{0.02}\right)_{\Sigma 1.96}\left(\mathrm{~S}_{3.02} \mathrm{Se}_{0.01} \mathrm{Sb}_{0.01}\right)_{\Sigma 3.04}$.

Dalším Bi sulfidem, který Ize ve vzorcích identifikovat i makroskopicky, je emplektit, tvořící až $4 \mathrm{~mm}$ dlouhé jehličkovité krystaly podobné bismutinitu. Většinou dosahují většího kovového lesku a nebývají navětralé. Identita makroskopických jehlic emplektitu byla potvrzena pomocí kvalitativní energiově-disperzní (EDS) analýzy. V nábrusu tvoří většinou xenomorfní laločnatá zrna do velikosti 0.4 $\mathrm{mm}$, někdy srůstá $\mathrm{s}$ bismutinitem či wittichenitem (obr. 23). Plocha nábrusu zachytila i jeho srůsty s nepojmenovaným Bi-Cu-Fe sulfidem, který do něho též zarůstá a vytváří až $40 \mu \mathrm{m}$ velká zrna. Při studiu chemického složení emplektitu (tab. 5) nebyly vedle $\mathrm{Cu}, \mathrm{Bi}$ a S zjištěny žádné 
příměsi. Průměrný (osm bodových analýz) empirický vzorec emplektitu z Jedové jámy je možno na bázi 4 apfu vyjádřit jako $\mathrm{Cu}_{1.00} \mathrm{Bi}_{0.98} \mathrm{~S}_{2.03}$.

$\mathrm{Na}$ dvou nábrusech byla $v$ křemenné žilovině zjištěna xenomorfní laločnatá, až $170 \mu \mathrm{m}$ velká zrna matilditu, která srůstají s chalkopyritem (obr. 13), wittichenitem (obr. $23)$, tetraedritem-(Zn) či Bi bohatým tetraedritem-(Zn) (obr. 14). V BSE obraze je matildit nezonální. Při studiu jeho chemického složení (tab. 6) byly vedle Ag, Bi a S zjištěny pouze minoritní příměsi Cu (0.015 - 0.095 apfu) a Fe (0 - 0.046 apfu). Průměrný (sedm bodových analýz) empirický vzorec matilditu z Jedové jámy je možno na bázi 4 apfu vyjádřit jako $\left(\mathrm{Ag}_{0.98} \mathrm{Cu}_{0.04}\right)_{\Sigma 1.02}\left(\mathrm{Bi}_{0.95} \mathrm{Fe}_{0.02}\right)_{\Sigma 0.97}$ $\mathrm{S}_{2.01}$.

Poměrně řídkým minerálem je aikinit tvořící v křemenné žilovině xenomorfní zrna o rozměrech 25 - $80 \mu \mathrm{m}$. Jeho zrna bývají obrůstána lemem Bi bohatého tennantitu -(Zn) (obr. 17). Aikinit srůstá s tetraedrit-tennantitem-(Zn), bismutinitem (obr. 21) či wittichenitem (obr. 20). Aikinit je v ČR poměrně vzácným minerálem, zjištěn byl pouze na

Tabulka 11 Chemické složení illitu (III), minerálu z kaolinitové skupiny (Kao) a topazu (Top) z Jedové jámy (hm. \%).

Obsahy $v \mathrm{hm}$. \%, hodnoty apfu jsou vypočítány na základ 11 (illit), 14 (minerál z kaolinitové skupiny), respektive pěti (topaz) atomů kyslíku na vzorcovou jednotku. I - suma mezivrstevních kationtů.

\begin{tabular}{|c|c|c|c|c|c|c|c|c|c|c|c|c|c|c|}
\hline An. č. & 1 & 2 & 3 & 4 & 5 & 6 & 7 & 8 & 9 & 10 & 11 & 12 & 13 & 14 \\
\hline Minerál & III & III & III & III & III & III & III & III & Kao & Kao & Kao & Top & Top & Top \\
\hline $\mathrm{P}_{2} \mathrm{O}_{5}$ & 0.00 & 0.00 & 0.07 & 0.00 & 0.00 & 0.00 & 0.00 & 0.04 & 0.06 & 0.08 & 0.00 & 0.70 & 0.09 & 0.30 \\
\hline $\mathrm{SiO}_{2}$ & 48.88 & 49.50 & 47.97 & 48.29 & 50.64 & 50.38 & 49.50 & 49.04 & 46.83 & 46.09 & 46.86 & 32.42 & 32.67 & 33.38 \\
\hline $\mathrm{Al}_{2} \mathrm{O}_{3}$ & 34.53 & 34.48 & 34.43 & 35.26 & 33.58 & 33.91 & 33.07 & 34.12 & 38.89 & 37.91 & 38.93 & 54.65 & 55.81 & 55.42 \\
\hline $\mathrm{MgO}$ & 0.63 & 0.79 & 0.38 & 0.40 & 1.12 & 0.85 & 0.79 & 0.76 & 0.00 & 0.00 & 0.00 & 0.21 & 0.00 & 0.16 \\
\hline $\mathrm{FeO}$ & 0.72 & 0.84 & 1.26 & 0.74 & 0.16 & 0.27 & 0.74 & 0.59 & 0.07 & 0.63 & 0.14 & 0.07 & 0.00 & 0.00 \\
\hline $\mathrm{ZnO}$ & 0.00 & 0.00 & 0.34 & 0.14 & 0.00 & 0.00 & 0.00 & 0.00 & 0.00 & 0.14 & 0.00 & 0.00 & 0.00 & 0.00 \\
\hline $\mathrm{CaO}$ & 0.10 & 0.09 & 0.26 & 0.18 & 0.00 & 0.13 & 0.19 & 0.11 & 0.00 & 0.04 & 0.00 & 0.00 & 0.00 & 0.00 \\
\hline $\mathrm{CuO}$ & 0.00 & 0.00 & 0.00 & 0.00 & 0.00 & 0.00 & 0.22 & 0.31 & 0.00 & 0.00 & 0.18 & 0.00 & 0.00 & 0.00 \\
\hline $\mathrm{Na}_{2} \mathrm{O}$ & 0.00 & 0.00 & 0.10 & 0.00 & 0.00 & 0.00 & 0.07 & 0.12 & 0.00 & 0.00 & 0.00 & 0.00 & 0.00 & 0.00 \\
\hline $\mathrm{K}_{2} \mathrm{O}$ & 9.15 & 9.21 & 9.42 & 9.66 & 9.21 & 9.40 & 9.48 & 9.59 & 0.00 & 0.00 & 0.05 & 0.00 & 0.00 & 0.00 \\
\hline $\mathrm{H}_{2} \mathrm{O}$ & 4.10 & 4.16 & 4.19 & 4.25 & 4.00 & 4.14 & 4.02 & 4.06 & 13.74 & 13.51 & 13.88 & 1.48 & 1.19 & 1.76 \\
\hline $\mathrm{F}$ & 0.91 & 0.85 & 0.67 & 0.62 & 1.24 & 0.96 & 1.04 & 1.02 & 0.39 & 0.41 & 0.14 & 17.54 & 18.27 & 17.22 \\
\hline $\mathrm{O}=\mathrm{F}$ & -0.38 & -0.36 & -0.28 & -0.26 & -0.52 & -0.40 & -0.44 & -0.43 & -0.16 & -0.17 & -0.06 & -7.39 & -7.69 & -7.25 \\
\hline Total & 98.64 & 99.56 & 98.81 & 99.28 & 99.43 & 99.64 & 98.68 & 99.33 & 99.82 & 98.64 & 100.12 & 99.68 & 100.34 & 100.99 \\
\hline$\overline{\mathrm{P}^{5+}}$ & 0.000 & 0.000 & 0.004 & 0.000 & 0.000 & 0.000 & 0.000 & 02 & 0.004 & 0.006 & 0.000 & 18 & 02 & .008 \\
\hline $\mathrm{Si}^{4+}$ & 3.233 & 3.245 & 3.194 & 3.189 & 3.309 & 3.292 & 3.285 & 3.236 & 4.032 & 4.032 & 4.029 & 0.993 & 0.995 & 1.008 \\
\hline $\mathrm{Al}^{3+}$ & 2.692 & 2.664 & 2.702 & 2.744 & 2.587 & 2.612 & 2.587 & 2.654 & 3.947 & 3.909 & 3.945 & 1.972 & 2.003 & 1.972 \\
\hline $\mathrm{Mg}^{2+}$ & 0.062 & 0.077 & 0.038 & 0.039 & 0.109 & 0.083 & 0.078 & 0.075 & 0.000 & 0.000 & 0.000 & 0.010 & 0.000 & 0.007 \\
\hline $\mathrm{Fe}^{2+}$ & 0.040 & 0.046 & 0.070 & 0.041 & 0.009 & 0.015 & 0.041 & 0.033 & 0.005 & 0.046 & 0.010 & 0.002 & 0.000 & 0.000 \\
\hline $\mathrm{Zn}^{2+}$ & 0.000 & 0.000 & 0.017 & 0.007 & 0.000 & 0.000 & 0.000 & 0.000 & 0.000 & 0.009 & 0.000 & 0.000 & 0.000 & 0.000 \\
\hline $\mathrm{Ca}^{2+}$ & 0.007 & 0.006 & 0.019 & 0.013 & 0.000 & 0.009 & 0.014 & 0.008 & 0.000 & 0.004 & 0.000 & 0.000 & 0.000 & 0.000 \\
\hline $\mathrm{Cu}^{2+}$ & 0.000 & 0.000 & 0.000 & 0.000 & 0.000 & 0.000 & 0.011 & 0.015 & 0.000 & 0.000 & 0.012 & 0.000 & 0.000 & 0.000 \\
\hline $\mathrm{Na}^{+}$ & 0.000 & 0.000 & 0.013 & 0.000 & 0.000 & 0.000 & 0.009 & 0.015 & 0.000 & 0.000 & 0.000 & 0.000 & 0.000 & 0.000 \\
\hline$\underline{\mathrm{K}^{+}}$ & 0.772 & 0.770 & 0.800 & 0.814 & 0.768 & 0.784 & 0.803 & 0.807 & 0.000 & 0.000 & 0.005 & 0.000 & 0.000 & 0.000 \\
\hline Catsum & 6.807 & 6.808 & 6.856 & 6.846 & 6.781 & 6.794 & 6.827 & 6.845 & 7.988 & 8.005 & 8.001 & 2.994 & 3.000 & 2.995 \\
\hline$\overline{\mathrm{OH}^{-}}$ & 1.810 & 1.820 & 1.861 & 1.872 & 1.744 & 1.805 & 1.780 & 1.788 & 7.894 & 7.885 & 7.963 & 0.302 & 0.242 & 0.355 \\
\hline $\mathrm{F}^{-}$ & 0.190 & 0.176 & 0.141 & 0.129 & 0.256 & 0.198 & 0.218 & 0.213 & 0.106 & 0.113 & 0.038 & 1.698 & 1.759 & 1.644 \\
\hline Ansum & 2.000 & 1.996 & 2.002 & 2.002 & 2.000 & 2.003 & 1.998 & 2.000 & 8.000 & 7.999 & 8.001 & 2.001 & 2.001 & 1.999 \\
\hline 1 & 0.779 & 0.777 & 0.832 & 0.826 & 0.768 & 0.793 & 0.836 & 0.846 & 0.000 & 0.004 & 0.017 & & & \\
\hline
\end{tabular}

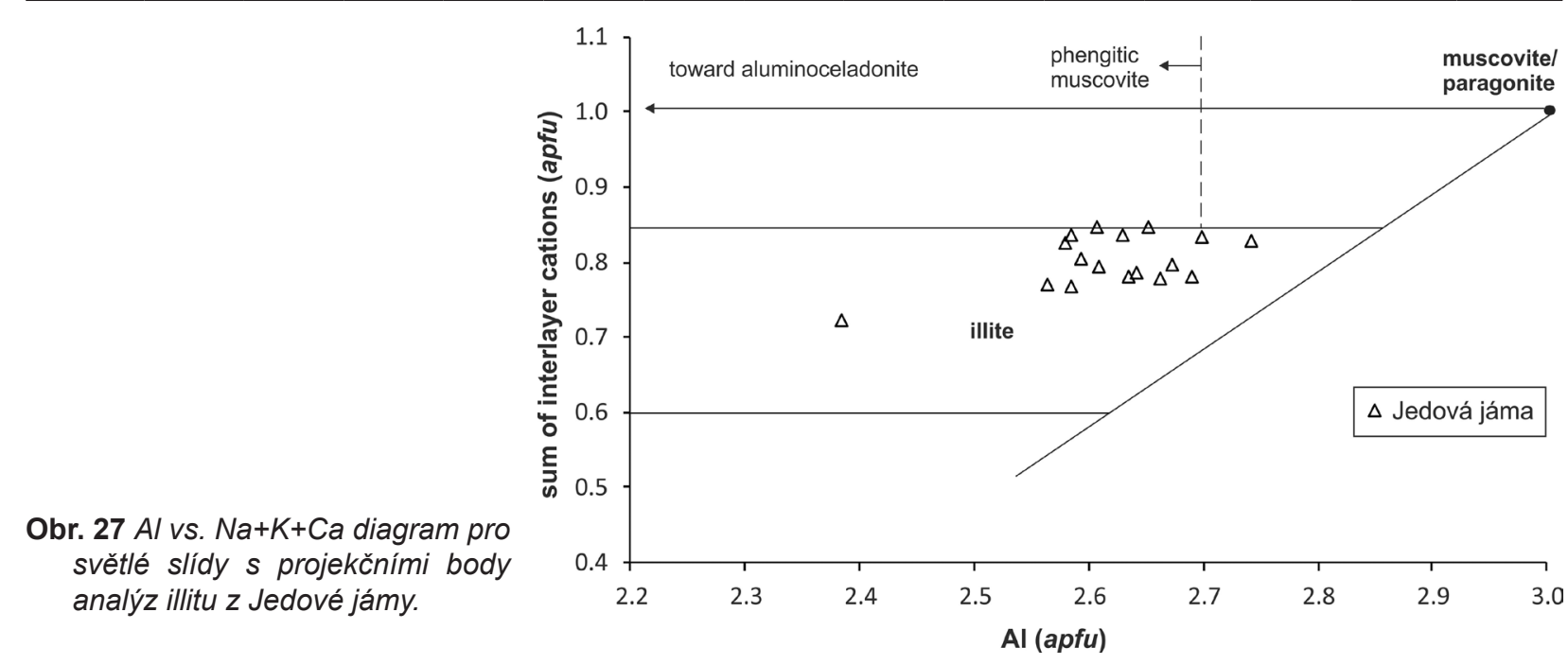


několika lokalitách - $v$ revíru Knötel na Horní Krupce (Prachař 1979), ve štole Giftkies a na dole Eliáš v Jáchymově (Ondruš et al. 2003) a v Moldavě v Krušných horách (Sejkora, Škácha 2015). Při studiu chemického složení aikinitu (tab. 6) byly vedle $\mathrm{Cu}, \mathrm{Pb}, \mathrm{Bi}$ a $\mathrm{S}$ zjištěny pouze minoritní príměsi Fe (0 - $0.085 a p f u)$. Průměrný (sedm bodových analýz) empirický vzorec aikinitu z Jedové jámy je možno na bázi 6 apfu vyjádřit jako $\mathrm{Pb}_{0.94} \mathrm{Cu}_{0.99} \mathrm{Fe}_{0.03} \mathrm{Bi}_{1.03} \mathrm{~S}_{3.00}$.

Ještě vzácnější sulfosolí je hammarit, který tu vytváři xenomorfní inkluze až $60 \mu \mathrm{m}$ velké, které zarưstají do bismutinitu (obr. 22). Na území ČR byl tento minerál dosud zjištěn pouze na Krupce, kde srůstá s krupkaitem a dalšími sulfosolemi aikinitové skupiny (Sejkora, Soumar, nepublikovaná data). Při studiu chemického složení hammaritu (tab. 7) nebyly vedle $\mathrm{Cu}, \mathrm{Pb}, \mathrm{Bi}$ a $\mathrm{S}$ zjištěny žádné

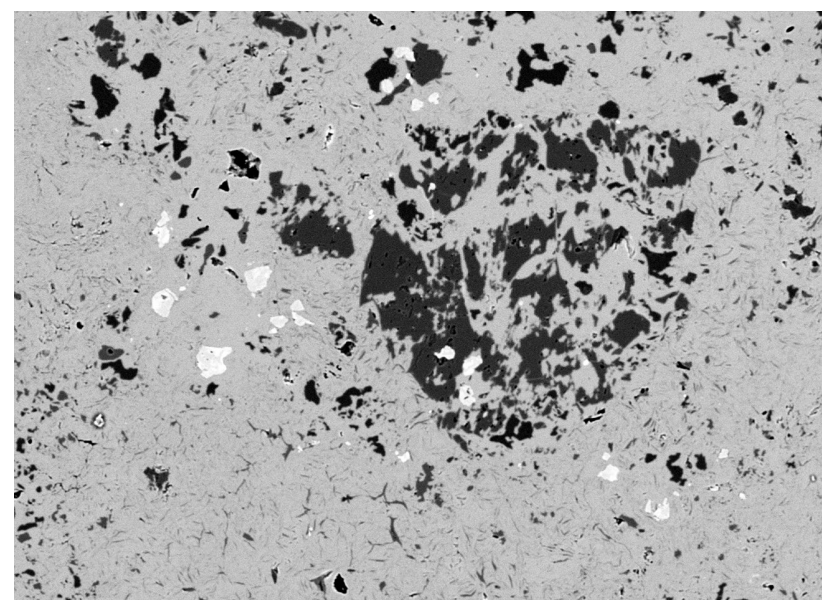

Obr. 28 Relikty topazu (černý) zarostlé ve fluoritu (středně šedá) s drobnými zrny rutilu (světle šedá); Jedová jáma; šířka záběru $580 \mu \mathrm{m}$, foto v BSE Z. Dolníček.

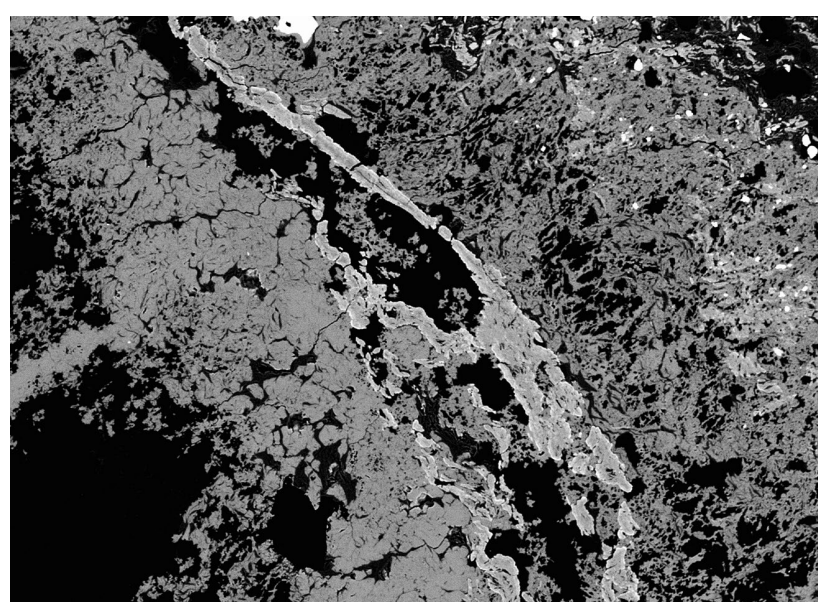

Obr. 29 Žilkovité agregáty goyazitu (světle šedý) ve fluoritu (tmavě šedý); Jedová jáma; šiřka záběru 920 m, foto $v$ BSE Z. Dolníček.

Tabulka 12 Chemické složení fluoritu z Jedové jámy. Obsahy $v$ hm. \%.

\begin{tabular}{lrrrrr}
\hline & 1 & 2 & 3 & 4 & 5 \\
\hline $\mathrm{Ca}$ & 51.97 & 53.20 & 52.34 & 52.88 & 52.66 \\
$\mathrm{~F}$ & 45.06 & 45.23 & 45.13 & 45.22 & 45.45 \\
$\mathrm{Y}$ & 0.22 & 0.18 & 0.26 & 0.19 & 0.24 \\
$\mathrm{Na}$ & 0.17 & 0.38 & 0.39 & 0.38 & 0.05 \\
$\mathrm{Al}$ & 0.28 & 0.10 & 0.43 & 0.29 & 0.24 \\
\hline Total & 97.70 & 99.09 & 98.55 & 98.96 & 98.64 \\
\hline
\end{tabular}

příměsi. Průměrný (čtyři bodové analýzy) empirický vzorec hammaritu z Jedové jámy je možno na bázi 17 apfu vyjádřit jako $\mathrm{Cu}_{2.00} \mathrm{~Pb}_{2.10} \mathrm{Bi}_{3.87} \mathrm{~S}_{9.02}$.

Zajímavým minerálem a jediným selenidem lokality je bohdanowiczit, selenový analog matilditu. Tvoří ojedinělá, maximálně $5 \mu \mathrm{m}$ velká xenomorfní zrna zarostlá $v$ korodovaném agregátu nepojmenovaného Bi-Cu-Fe sulfidu ve fluoritu či až $10 \mu \mathrm{m}$ velká zrna v tennantitu-(Zn) či wittichenitu (obr. 24). Tento poměrně vzácný selenid byl na území ČR zjištěn dosud na uranových ložiscích Zlatkov u Rožné (Kvaček 1979), Zálesí u Javorníka ve Slezsku (Sejkora et al. 2007), Potůčky v Krušných horách (Sejkora et al. 2017) a na fluoritovém ložisku Moldava v Krušných horách (Sejkora, Škácha 2015). Při studiu chemického složení bohdanowiczitu (tab. 7) byly vedle $\mathrm{Ag}, \mathrm{Bi}$ a Se zjištěny minoritní příměsi $\mathrm{Cu}(0.123$ 0.215 apfu), Zn (0.03 - 0.029 apfu) a S (0.119 - 0.307 apfu). Průměrný (šest bodových analýz) empirický vzorec bohdanowiczitu $z$ Jedové jámy je možno na bázi 4 apfu vyjádřit jako $\mathrm{Ag}_{0.94} \mathrm{Cu}_{0.14} \mathrm{Zn}_{0.02} \mathrm{Bi}_{0.95}\left(\mathrm{Se}_{1.74} \mathrm{~S}_{0.20}\right)_{\Sigma 1.94}$

Nepríliš častá xenomorfní zrna o rozměrech do 180 $\mu \mathrm{m}$ tvoří $\mathrm{v}$ žilovině wittichenit, který srůstá $\mathrm{s}$ aikinitem (obr. 20), bismutinitem nebo emplektitem (obr. 23), v jednom prípadě do jeho zrna zarůstá $10 \mu \mathrm{m}$ velká inkluze bohdanowiczitu (obr. 24). Při studiu chemického složení wittichenitu (tab. 8) byly vedle $\mathrm{Cu}, \mathrm{Bi}$ a S zjištěny minoritní príměsi $\mathrm{Ag}$ (0.014 - $0.026 \mathrm{apfu})$ a Se (0.004 - $0.011 \mathrm{apfu})$. Průměrný (osm bodových analýz) empirický vzorec wittichenitu z Jedové jámy je možno na bázi 7 apfu vyjádřit jako $\mathrm{Cu}_{2.93} \mathrm{Ag}_{0.02} \mathrm{Bi}_{1.00}\left(\mathrm{~S}_{3.04} \mathrm{Se}_{0.01}\right)_{\Sigma 3.05}$

Ojediněle bylo $v$ nábrusu analyzováno xenomorfní zrno bournonitu o velikosti $100 \mu \mathrm{m}$. Při studiu jeho chemického složení (tab. 8) byl vedle $\mathrm{Cu}, \mathrm{Pb}, \mathrm{Sb}$ a $\mathrm{S}$ zjištěn zvýšený obsah As (0.207 - 0.295 apfu), odpovídající menšinovému zastoupení As-dominantního analogu seligmannitu, tvořícího s bournonitem izomorfní řadu. Průměrný (šest bodových analýz) empirický vzorec bournonitu z Jedové jámy je možno na bázi 6 apfu vyjádřit jako $\mathrm{Cu}_{0.94} \mathrm{~Pb}_{0.96}\left(\mathrm{Sb}_{0.77} \mathrm{As}_{0.25}\right)_{\Sigma 1.02} \mathrm{~S}_{3.00}$.

Poměrně velká $(0.5 \mathrm{~mm})$ laločnatá zrna tu tvoří kësterit, který většinou srůstá s tetraedritem-(Zn), někdy ho lemuje, a stanoiditem (obr. 19, 25). Kësterit je v ČR poměrně vzácným minerálem, který byl dosud velmi vzácně zjištěn spolu se staninem ve Vernéřově u Aše (Breiter et al. 2009), na Cínovci (David et al. 1991), v Huberově pni v Krásně (Beran 1999), Jáchymově (Ondruš et al. 2003), Malovidech u Českého Šternberka (Šrein et al. 2007) a v dole Bohuliby $\vee$ jílovském zlatonosném revíru (Sejkora, Litochleb 2009). Při studiu chemického složení kësteritu (tab. 9) byl vedle $\mathrm{Cu}, \mathrm{Zn}, \mathrm{Sn}$ a S zjištěn zvýšený obsah Fe (0.132 - $0.179 a p f u$ ), odpovídající menšinovému podílu staninové složky. Vedle toho obsahuje tento kësterit minoritní príměsi Cd (0.008 - 0.011 apfu) a In (0.004 - 0.008 apfu). Průměrný (osm bodových analýz) empirický vzorec kësteritu $z$ Jedové jámy je možno na bázi čtyř atomů $S$ vyjádřit jako $\mathrm{Cu}_{2.02}\left(\mathrm{Zn}_{0.90} \mathrm{Fe}_{0.15} \mathrm{Cd}_{0.01}\right)_{\Sigma 1.06} \mathrm{Sn}_{0.99} \mathrm{~S}_{4.00}$.

Lemy a srůsty $\mathrm{s}$ kësteritem, prípadně tetraedritem (obr. 19), o rozměrech až $20 \times 100 \mu \mathrm{m}$ tvoří stanoidit, který byl zatím v ČR zjištěn pouze na Huberově pni v Krásně (Pavlů 1984; Kovář 2012). Při studiu jeho chemického složení (tab. 9) byla vedle $\mathrm{Cu}, \mathrm{Fe}, \mathrm{Zn}$, Sn a S zjištěna pouze minoritní príměs Cd (0.005 - 0.022 apfu). Průměrný (sedm bodových analýz) empirický vzorec stanoiditu $z$ Jedové jámy je možno na bázi 12 atomů síry vyjádřit jako $\mathrm{Cu}_{7.69}\left(\mathrm{Fe}_{2.03} \mathrm{Zn}_{0.92} \mathrm{Cd}_{0.01}\right)_{\Sigma 2.96} \mathrm{Sn}_{2.11} \mathrm{~S}_{12.00}$.

Poslední zjištěnou sulfidickou fází $\mathrm{v}$ analyzovaných 
nábrusech je nepojmenovaný Bi-Cu-Fe sulfid, který tvoří až $60 \mu \mathrm{m}$ velká nepravidelná korodovaná zrna zarůstající do křemene či fluoritu, obsahující vzácně maximálně $5 \mu \mathrm{m}$ velká zrna bohdanowiczitu či ryzího bismutu (obr. 26). Při studiu jeho chemického složení (tab. 10) byly vedle $\mathrm{Bi}, \mathrm{Cu}, \mathrm{Fe}$ a $\mathrm{S}$ zjištěny minoritní príměsi $\mathrm{Ag}(0.002$ 0.006 apfu), Sb (0.003 - 0.013 apfu) a Se (0 - 0.021 apfu). Průměrný (sedm bodových analýz) empirický vzorec tohoto sulfidu z Jedové jámy je možno na bázi šesti atomů na vzorcovou jednotku vyjádřit jako $\left(\mathrm{Cu}_{1.48} \mathrm{Fe}_{0.50}\right)_{\Sigma 1.98}$ $\left(\mathrm{Bi}_{0.96} \mathrm{Sb}_{0.01}\right)_{\Sigma 0.97}\left(\mathrm{~S}_{3.03} \mathrm{Se}_{0.01}\right)_{\Sigma 3.04}$. Stechiometrie námi nalezené fáze je blízká nepojmenované fázi $(\mathrm{Cu}, \mathrm{Ni})_{2} \mathrm{BiS}_{3}$, popsané Jakovlevem et al. (1972) z Cu-Ni rud ložiska Allarechenskoe, poloostrov Kola, Rusko, kde daná fáze tvoři tenký lem kolem parkeritu.

Se sulfidy je úzce spjatý ojedinělý ryzí bismut, tvořící v křemeni drobná xenomorfní zrna o velikosti do 30 $\mu \mathrm{m}$ (obr. 20). Kolem $30 \mu \mathrm{m}$ velké bismutové zrno bylo též zastižené v nepojmenovaném Bi-Cu-Fe sulfidu (obr. 26). $Z$ chemického hlediska obsahuje pouze malou príměs $\mathrm{Fe}$ (0.74 hm. \%).

Vedle sulfidů se v menším množství vyskytují v křemenné žilovině lokálně nahloučené žilkovité či nepravidelné jemnozrnné agregáty fylosilikátů, jejichž jednotlivé lupínky dosahují velikosti $10 \mu \mathrm{m}$ (obr. 9, 10). Po chemické stránce (tab. 11) jde podle klasifikace Riedera et al. (1998) o illit (obr. 27), méně často o minerál z kaolinitové skupiny. Do jejich agregátů zarůstají ojedinělá zrna rutilu. Minerál z kaolinitové skupiny také silně zatlačuje topaz. Chemismus obou fylosilikátů se vyznačuje zvýšenými obsahy fluoru (až 0.26 apfu u illitu a 0.11 apfu u minerálu z kaolinitové skupiny; tab. 11).

Spolu s agregáty slíd byla v ploše nábrusu zachycena xenomorfní zrna topazu dosahující velikosti až $100 \mu \mathrm{m}$, která v některých případech zarůstají do fluoritu (obr. 28).
Jsou silně zatlačována jílovým minerálem z kaolinitové skupiny. Chemické složení topazu (tab. 11) odpovídá jeho stechiometrii. Obsahuje 12 - 18 mol. \% OH-koncového členu.

Na ploše nábrusů byl zachycen a analyzován i poměrně častý fluorit, který tvoři až několik mm velká zrna $v$ křemenné žilovině. Někdy obsahuje žilkovité agregáty goyazitu (obr. 24, 29) či uzavírá topaz a rutil (obr. 28). Vedle Ca a $\mathrm{F}$ obsahuje příměsi Y $(0.18-0.26 \mathrm{hm}$. \%), Al $(0.10-0.46 \mathrm{hm} . \%)$ a Na $(0.05-0.39 \mathrm{hm} . \%)$ (tab. 12).

$\mathrm{S}$ fluoritem srůstají nepravidelně omezená zrna fluorapatitu dosahující velikosti $0.2 \mathrm{~mm}$. Vedle $\mathrm{CaO}, \mathrm{P}_{2} \mathrm{O}_{5}$ a F obsahuje malou príměs $\mathrm{SO}_{3}(0.25-0.32 \mathrm{hm}$. \%).

Členitá, xenomorfně omezená, až $150 \mu \mathrm{m}$ velká zrna a jejich agregáty tvoří v křemeni (obr. 26) kasiterit. Tvoří též agregáty s kolomorfní strukturou (obr. 30). Obsahuje pře-

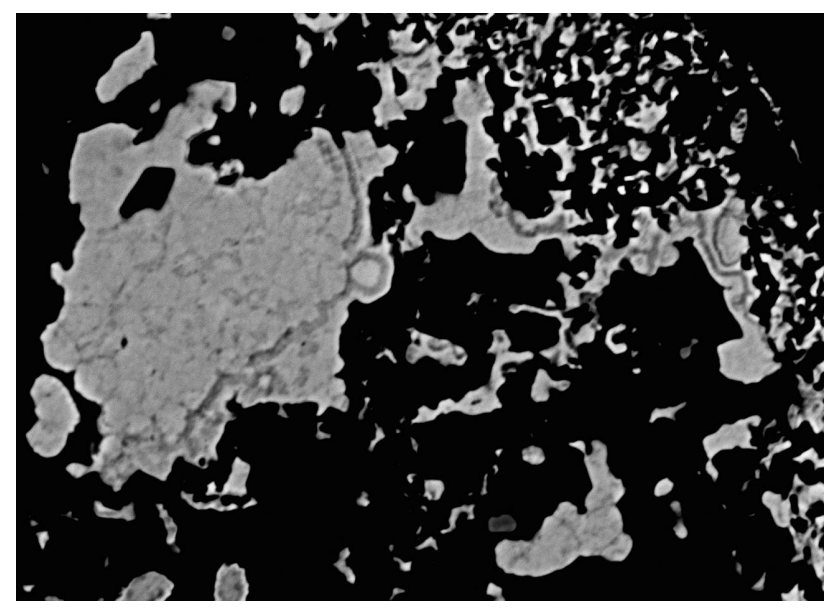

Obr. 30 Kolomorfní agregát kasiteritu; šírka záběru 140 $\mu m$, foto $v$ BSE Z. Dolníček.

Tabulka 13 Chemické složení kasiteritu (Cas) a rutilu (Rt) z Jedové jámy. Obsahy oxidů jsou v hm. \%, hodnoty apfu jsou vyjádřeny na základ dvou atomů kyslíku.

\begin{tabular}{|c|c|c|c|c|c|c|c|c|c|c|c|c|c|c|}
\hline An. č. & mean & 1 & 2 & 3 & 4 & 5 & 6 & ean & 7 & 8 & 9 & 10 & 11 & \\
\hline Minerál & Cas & Cas & Cas & Cas & Cas & Cas & as & Rt & I & t & $\mathrm{Rt}$ & Rt & t & \\
\hline $\mathrm{O}$ & & 0.80 & 0.80 & 0.74 & 0.76 & 0.89 & 0.83 & & 61 & 84 & & .56 & & \\
\hline${ }_{2} \mathrm{O}_{5}$ & 0 & 0.00 & 0.00 & 00 & 0.00 & .00 & 0.00 & .23 & 0.18 & 0.27 & .29 & 0.21 & 0.3 & \\
\hline $\mathrm{S}_{2} \mathrm{O}_{5}$ & 0.90 & 0.96 & 0.96 & 0.84 & 0.84 & 0.94 & 0.86 & 0.00 & 0.00 & 0.00 & 0.00 & 0.00 & 0.00 & \\
\hline & 0.00 & 0.00 & 0.00 & 0.00 & 0.00 & 0.00 & 0.00 & 87.60 & 83.73 & 80.77 & .89 & 92.52 & 89.46 & 90.4 \\
\hline $\mathrm{O}_{2}$ & 64 & 2.54 & 2.78 & 2.42 & 2.74 & 2.68 & 2.68 & 12 & 39 & 23 & 1 & 0.00 & 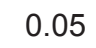 & \\
\hline $\mathrm{nO}_{2}$ & 39.07 & 3.83 & .29 & 9.08 & 9.50 & 8.67 & 05 & 40 & 35 & 54 & 58 & 0.34 & .48 & \\
\hline${ }_{2} \mathrm{O}_{3}$ & 48 & 0.47 & 47 & 44 & 0.47 & 50 & 50 & 00 & 0.00 & 00 & 00 & 0.00 & 0.00 & 0.4 \\
\hline $\mathrm{O}_{3}$ & & 52 & & 54 & 57 & 53 & 66 & 19 & 97 & 13 & 8 & 2.27 & 9 & \\
\hline $\mathrm{r}_{2} \mathrm{O}_{3}$ & 0 & 0 & 0 & 00 & 00 & 00 & 0.00 & 8 & 4.16 & 76 & 3 & 1.03 & 1. & \\
\hline & & 7 & 6 & 8 & 24 & 22 & 89 & & 20 & & & 0.11 & 5 & \\
\hline $\mathrm{O}$ & & & & & & & & & & & & 0.00 & 0 & \\
\hline tal & 00 & 36 & .04 & 27 & .01 & 35 & 59 & 92 & 59 & 72 & 9 & 03 & .06 & \\
\hline & 11 & 5 & 55 & 5 & 55 & 06 & 5 & & 8 & & & 13 & 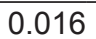 & \\
\hline $5+$ & & 0 & 0 & 0 & 00 & 0 & 0 & & & & & 01 & 02 & \\
\hline $5+$ & & 2 & & & 1 & 2 & & & & & & 00 & 00 & \\
\hline & & 00 & & & & & & & & & & & 35 & \\
\hline & & 62 & & & & 65 & & & & & & 00 & 01 & \\
\hline$n^{4+}$ & & & & & & & & & & & & & & \\
\hline & & & & & & & & & & & & 00 & 00 & \\
\hline 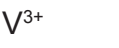 & & & & & & & & & & & & 25 & & \\
\hline $\mathrm{Cr}^{3+}$ & & & & & & & & & & & & & 16 & \\
\hline & & 42 & & & & & & & & & & & 02 & \\
\hline $\mathrm{Ca}^{2+}$ & & 04 & 3 & 3 & 2 & 3 & 3 & & 0.000 & & & & .000 & \\
\hline 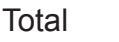 & 30 & 028 & 1.028 & 1.029 & 1.028 & .027 & 1.027 & 1.005 & 1.004 & 1.007 & 1.006 & 1.003 & 1.004 & 1 \\
\hline
\end{tabular}



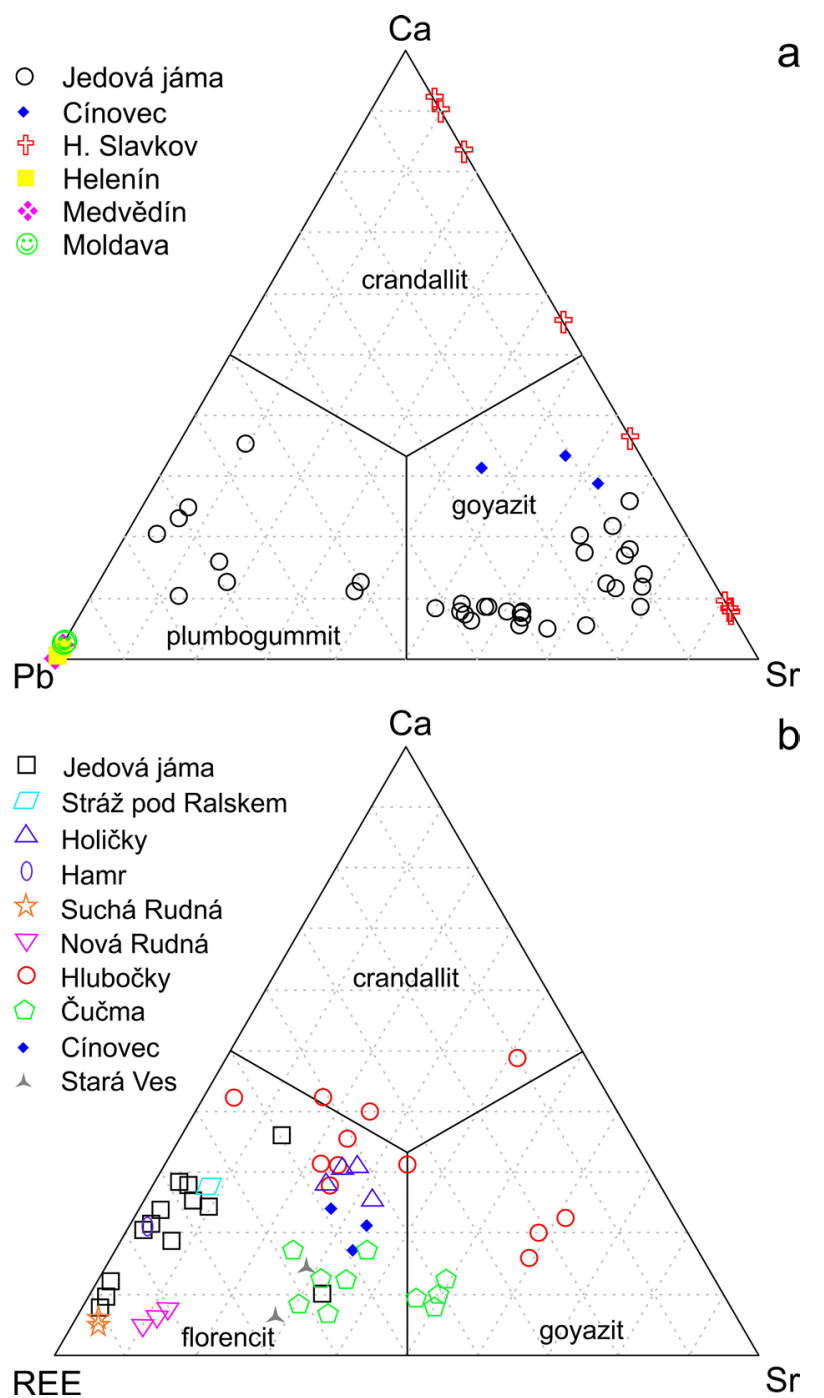

Obr. 31 Variace $v$ chemickém složení minerálů plumbogummitové rady z lokality Jedová jáma v porovnání s dalšími lokalitami. a - diagram Pb-Ca-Sr pro REE-chudé členy, b - diagram REE-Ca-Sr pro REE-bohaté členy. Srovnávací data jsou prevzata z prací Nováka et al. (1989), Scharma et al. (1994), Sejkory et al. (1998, 2006, 2009), Kučery et al. (2007), Plášila et al. (2009), Kocourkové et al. (2010), Števka et al. (2014) a Kotlánové et al. (2016).

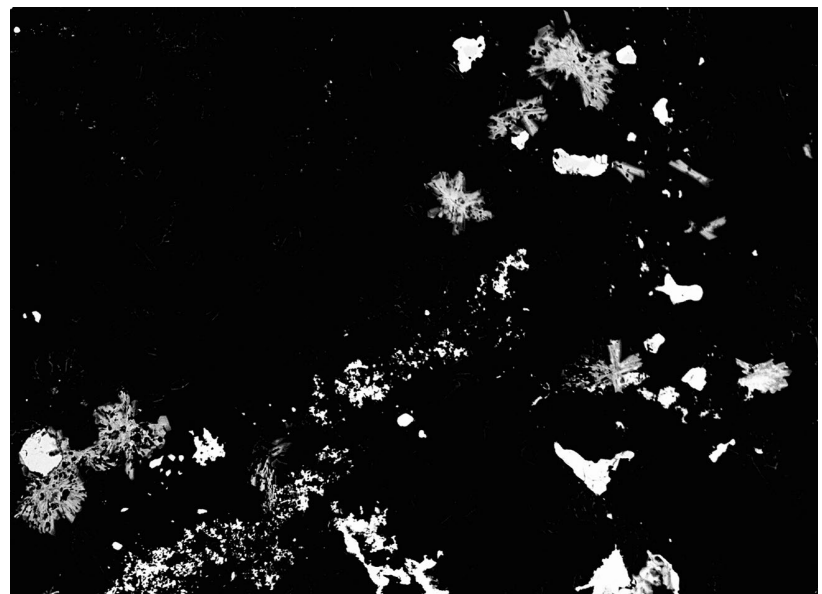

Obr. 32 Jehličkovité krystaly a agregáty plumbogummitu (středně šedý); Jedová jáma; šírka záběru $600 \mu m$, foto $v$ BSE Z. Dolníček. devším príměsi $\mathrm{SiO}_{2}(0.058-0.066$ apfu $\mathrm{Si}), \mathrm{V}_{2} \mathrm{O}_{3}(0.029$ - 0.032 apfu V) a FeO (0.037 - 0.042 apfu Fe) (tab. 13).

Oválná, až $100 \mu \mathrm{m}$ velká xenomorfní i automorfně omezená zrna a jejich agregáty tvoří rutil. Srůstá $s$ arsenopyritem, vyskytuje se též izolovaně v křemenné žilovině, ve fluoritu či florencitu-(Ce). V ploše nábrusu byl zachycen výrazně zonální automorfně vyvinutý rutil, ve kterém se střídají tmavší ( $v$ obraze BSE) zóny chemicky čistého $\mathrm{TiO}_{2}$ se světlejšími zónami rutilu $s$ príměsí $W$ a dalších prvků (obr. 11). Vedle převažujícího rutilu bez větších príměsí (tab. 13, anal. 12) se spolu s ním vyskytuje v křemenné žilovině rutil se zvýšenými obsahy W $(0.013$ - 0.033 apfu $), \operatorname{Cr}(0.011-0.066$ apfu) a V (0.025 - 0.046 apfu) (tab. 13, anal. 7 - 11). Rutilová inkluze ve florencitu je po chemické stránce téměř bez príměsí.

Pestrou asociaci minerálů zjištěných ve studovaných nábrusech doplňují fosfáty plumbogummitové skupiny. Jde o plumbogummit, goyazit a florencit-(Ce) (obr. 31). Plumbogummit tvoři v nábrusech jehličkovité krystaly s radiálně paprsčitým uspořádáním (obr. 32), v některých případech vytváŕí zonální srůsty s goyazitem (obr. 33). Goyazit tvoři protáhlá zonální zrna až $150 \mu \mathrm{m}$ velká a mikroskopické mladé žilky protínající křemennou, illitovou (obr. 10) či fluoritovou (obr. 29) žilovinu. Agregáty jehličkovitých krystalů až $100 \mu \mathrm{m}$ velké zarostlé v křemeni tvoří florencit-(Ce) (obr. 34), který též v nábrusech srůstá

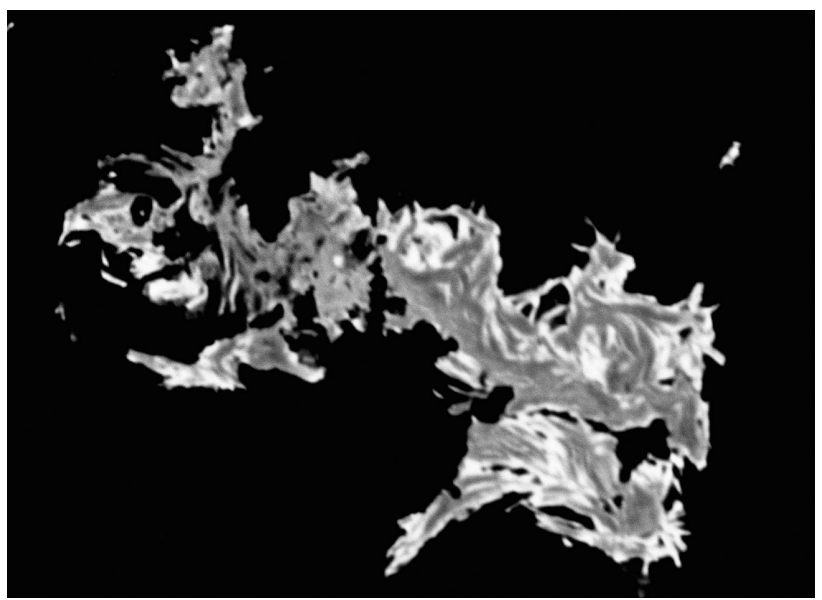

Obr. 33 Zonální agregát goyazitu (tmavě šedý) a plumbogummitu (světle šedý); Jedová jáma; šiřka záběru 150 $\mu m$, foto $v$ BSE Z. Dolníček.

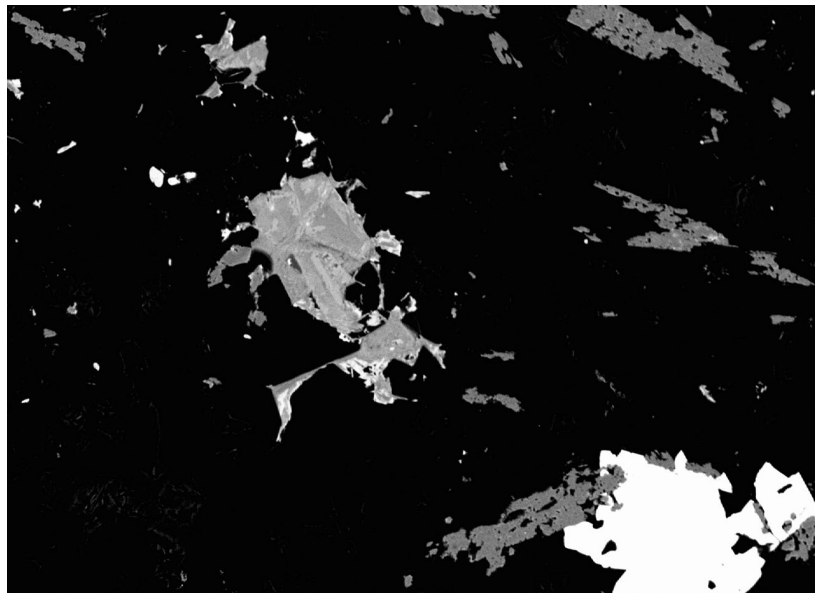

Obr. 34 Arsenopyrit (bílý), zonální zrno florencitu-(Ce) (světle šedý) a zrna rutilu (tmavěji šedý); Jedová jáma; šiřka záběru $520 \mu m$, foto v BSE Z. Dolníček. 
S chalkopyritem, kdy do něho zarůstají až $20 \mu \mathrm{m}$ velká oválná zrna rutilu (obr. 15).

V BSE obraze jsou jejich zrna zonální. V souladu se známou neomezenou izomorfií $v$ minerálech této skupiny obsahují výše uvedené minerály i významné obsahy dalších členů. $V$ aniontové části vzorce vždy převažuje fosfor, který je částečně zastupován As (až 0.21 apfu), S (až $0.56 \mathrm{apfu}$ ) a ojediněle i Si (u něhož nelze vyloučit, že jde o anizominerální príměs $z$ okolí). Většina analýz vykazuje deficit obsahu prvků $\vee$ pozici $P$, je tedy možné, že dané fáze obsahují v této pozici i uhlík (tab. 14 - 15). Většina získaných analýz obsahuje i zvýšený podíl $\mathrm{F}$ (až 0.65 apfu). Reprezentativní príklady bodových chemických analýz goyazitu jsou uvedeny v tabulce 14 . Obsahy goyazitové komponenty se pohybují v rozmezí 63.1 - 77.3, crandallitové 8.6 - 21.8, plumbogummitové 9.1 - 15.6 a gorceixitové 1.0 - 2.1 (mol. \%). Príklady bodových chemických analýz plumbogummitu jsou uvedeny v tabulce 14 . Obsahy plumbogummitové komponenty se u jednotlivých analýz pohybují v rozmezí 53.6 - 74.4, crandallitové 10.2 - 34.7, goyazitové 4.0 - 17.4 a florencitové 0.0 - 1.0 (mol. $\%)$. Výsledky bodových chemických analýz florencitu-(Ce) jsou uvedeny $v$ tabulce 15 . Obsahy florencitové komponenty se u jednotlivých analýz pohybují v rozmezí 56.3 87.4, crandallitové 9.9 - 23.8, goyazitové 1.9 - 32.5, plumbogummitové 0.0 - 0.8 a gorceixitové 0.0 - 6.0 (mol. \%).

Ve spektru prvků vzácných zemin ve florencitu převažuje Ce, jde tedy klasifikačně o florencit-(Ce). Chondritem

Tabulka 14 Chemické složení goyazitu (Goy) a plumbogummitu (Pbg) z Jedové jámy (hm. \%). Koeficienty empirických vzorců počitány na bázi šesti kationtů na vzorcovou jednotku, obsah $\mathrm{CO}_{2}$ dopočten na bázi $A s+P+S+C+S i=2$ apfu, obsah vody dopočten na základ $1 \mathrm{H}_{2} \mathrm{O}$ a $5(\mathrm{OH}+\mathrm{F})$. Obsahy koncových členů v mol. \%.

\begin{tabular}{|c|c|c|c|c|c|c|c|c|c|c|c|c|c|c|}
\hline An. č. & 1 & 2 & 3 & 4 & 5 & 6 & 7 & 0 & $y$ & 10 & 11 & 2 & 10 & \\
\hline Minerá & Goy & Goy & Goy & Goy & Goy & Goy & Goy & $\mathrm{Pbg}$ & $\mathrm{Pbg}$ & $\mathrm{Pbg}$ & $\mathrm{Pbg}$ & & $\mathrm{Pbg}$ & \\
\hline $\mathrm{SO}_{3}$ & 7.65 & 7.11 & 6.44 & 7.05 & 7.29 & 7.99 & 6.08 & 6.92 & 5.59 & 7.13 & 7.16 & 6.26 & 6.43 & 7.6 \\
\hline $\mathrm{P}_{2} \mathrm{O}_{5}^{3}$ & 9.41 & 2.11 & 22.06 & 20.41 & 20.71 & 20.50 & 22.12 & 16.70 & 17.43 & 14.87 & 14.91 & 13.82 & 12.63 & 4.4 \\
\hline $\mathrm{As}_{2} \mathrm{O}_{5}$ & .56 & 0.17 & 0.32 & 0.35 & 0.28 & 0.31 & 0.00 & 0.68 & 1.03 & 1.04 & 1.13 & 4.01 & 4.01 & 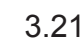 \\
\hline $\mathrm{CO}_{2}$ & 0.00 & 0.00 & 0.00 & 0.00 & 0.00 & 0.00 & 0.00 & 1.45 & 1.37 & 2.44 & 2.38 & 3.24 & 3.29 & 1.5 \\
\hline $\mathrm{SiO}_{2}$ & 0.77 & 0.00 & 0.00 & 0.25 & 0.00 & 0.25 & 0.00 & 0.00 & 0.00 & 0.00 & 0.00 & 0.00 & 0.00 & 0.0 \\
\hline $\mathrm{Al}_{2} \mathrm{O}_{3}$ & 29.47 & 29.14 & 28.95 & 29.00 & 28.41 & 28.97 & 28.80 & 27.46 & 26.68 & 27.14 & 27.18 & 27.53 & 26.79 & 27. \\
\hline $\mathrm{Fe}_{2} \mathrm{O}_{3}$ & 0.13 & 0.00 & 0.00 & 0.00 & 0.13 & 0.18 & 0.19 & 0.00 & 0.28 & 0.00 & 0.00 & 0.12 & 0.31 & 0. \\
\hline $\mathrm{Ce}_{2} \mathrm{O}_{3}$ & 0.00 & 0.00 & 0.00 & 0.00 & 0.00 & 0.00 & 0.00 & 0.17 & 0.22 & 0.00 & 0.15 & 0.36 & 0.22 & $0 . C^{2}$ \\
\hline $\mathrm{aO}$ & .30 & 1.59 & 2.51 & 0.91 & 1.99 & 2.24 & 1.99 & 1.56 & 1.25 & 2.62 & 2.43 & 4.28 & .32 & .c \\
\hline 0 & 62 & .87 & 4.38 & .17 & .74 & .97 & .71 & & 3.28 & .22 & .12 & 2.06 & & 2.1 \\
\hline $\mathrm{aO}$ & 61 & 47 & 0.31 & 54 & 55 & 0.52 & 0.65 & 1.41 & 1.00 & 0.68 & 0.79 & 0.58 & 61 & $0 . s$ \\
\hline $\mathrm{OO}$ & 27 & & 4.42 & 18 & 13 & 6.65 & 7.12 & 26.47 & 26.92 & 3.67 & 29.45 & 33 & & 9.6 \\
\hline 0 & 20 & & 0.21 & 36 & 20 & 17 & 0.12 & & 0.07 & 11 & 0.07 & & & 0.2 \\
\hline $\mathrm{H}_{2} \mathrm{O}$ & 52 & .77 & 1.87 & .54 & 0.94 & 11.95 & 11.72 & 10.98 & 10.65 & 1.17 & 11.20 & 11.30 & 10.84 & 0.6 \\
\hline$F^{2}$ & 34 & & .90 & 11 & 2.36 & 0.65 & 1.01 & 30 & 1.15 & 56 & 0.51 & 1.50 & 59 & 1.2 \\
\hline-1 & .56 & .55 & .38 & .47 & .99 & .27 & .43 & 34 & 0.48 & .24 & 0.21 & 0.63 & 67 & -0.5 \\
\hline otal & 29 & .24 & 99 & & 74 & .07 & 08 & & 43 & 41 & 8.27 & .81 & & 9.2 \\
\hline & 95 & 52 & 12 & 60 & 76 & 513 & 92 & 79 & 93 & 90 & 492 & 410 & & 53 \\
\hline & & & 92 & & & & & & 82 & & 56 & 21 & & \\
\hline$s^{5+}$ & 25 & & 14 & & 13 & 14 & 0 & & 50 & & 54 & & & 15 \\
\hline & & & 00 & & & & & & & & 98 & & & 17 \\
\hline $4^{4+}$ & 66 & 00 & .000 & 022 & 000 & 0.021 & 0.000 & 00 & .000 & 00 & .000 & .000 & & 0.00 \\
\hline$T \mathrm{su}$ & & 44 & 18 & 00 & 13 & 32 & 02 & 00 & & & .000 & 000 & & .00 \\
\hline $3+$ & 97 & 08 & 908 & 71 & 12 & 19 & 19 & & 45 & & 34 & 32 & & 96 \\
\hline $\mathrm{e}^{3+}$ & 09 & 00 & 0.000 & 00 & 09 & 011 & 012 & & 020 & 00 & .000 & 008 & & 01 \\
\hline$B$ sum & 05 & 08 & 08 & & 21 & 31 & 31 & & & & 34 & 340 & & .97 \\
\hline $\mathrm{e}^{3+}$ & & & 00 & 0 & & & & & 08 & & 05 & 12 & & .00 \\
\hline 2 & & & 29 & & & & & & & & & 00 & & 10 \\
\hline $2+$ & 81 & 79 & 11 & 65 & 43 & 43 & 84 & & 78 & 65 & 59 & 04 & & .11 \\
\hline & & & & & & & & & & & & & & 0 \\
\hline & & & & & & & & & & & & & & 74 \\
\hline$K$ & 22 & 14 & 23 & 40 & 22 & 19 & 13 & 00 & 08 & 13 & 08 & 06 & & 0.02 \\
\hline su & 90 & 47 & 1.074 & 29 & 66 & 37 & 67 & 14 & 35 & 67 & 1.066 & 160 & 23 & 02 \\
\hline $\mathrm{H}^{-}$ & 36 & 54 & 54 & 98 & & 21 & 28 & & 59 & 37 & 49 & 84 & & 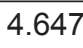 \\
\hline $\mathrm{F}$ & 366 & 348 & 0.243 & 0.305 & 0.649 & 0.176 & 0.275 & 0.233 & 0.341 & 0.162 & 0.148 & 0.414 & 0.455 & .35 \\
\hline $\mathrm{H}+$ & 001 & .002 & 4.996 & 5.003 & 5.000 & 4.997 & .002 & .999 & .000 & 5.000 & .997 & 4.998 & 5.001 & 5.00 \\
\hline $\mathrm{H}_{2} \mathrm{O}$ & 1 & 1 & 1 & 1 & 1 & 1 & 1 & 1 & 1 & 1 & 1 & 1 & 1 & \\
\hline oy & .4 & & 6 & 77.3 & 1.2 & .1 & .9 & & .4 & 6.2 & 5.6 & 9.0 & .0 & 11 \\
\hline ra & 12.4 & 14.0 & 21.8 & 8.6 & 17.8 & 20.1 & & & 12.2 & 24.4 & 22.5 & 4.1 & & 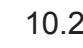 \\
\hline $\mathrm{bg}$ & 15.0 & 9 & 9.6 & 12.3 & 9.3 & 15.0 & 15.6 & 64.9 & 66.1 & 67.1 & 68.7 & 53.6 & 3.2 & 74 \\
\hline & 2 & 1.5 & 1.0 & 1.5 & 1.8 & 1.7 & 2.1 & 5.0 & 3.6 & 2.3 & 2.7 & 1.7 & .9 & \\
\hline 口 & 0.0 & 0.0 & 0.0 & 0.0 & 0.0 & 0.0 & 0.0 & 0. & 0.7 & 0.0 & 0.5 & 1 & 0.7 & \\
\hline
\end{tabular}


Tabulka 15 Chemické složení florencitu-(Ce) z Jedové jámy (hm. \%). Koeficienty empirických vzorců počitány na bázi šesti kationtů na vzorcovou jednotku, obsah $\mathrm{CO}_{2}$ dopočten na bázi $A s+P+S+C=2$ apfu, obsah vody dopočten na základ $6(\mathrm{OH}+\mathrm{F})$. Obsahy koncových členů jsou v mol. \%. REE parametry počitány z hodnot normalizovaných C1 chondritem.

\begin{tabular}{|c|c|c|c|c|c|c|c|c|c|c|c|c|c|}
\hline An. č. & 1 & 2 & 3 & 4 & 5 & 6 & 7 & 8 & 9 & 10 & 11 & 12 & 13 \\
\hline$\overline{\mathrm{SO}_{3}}$ & 1.96 & 0.37 & 0.33 & 0.73 & 0.44 & 0.10 & 0.13 & 0.32 & 0.83 & 0.46 & 0.18 & 0.04 & 0.21 \\
\hline $\mathrm{P}_{2} \mathrm{O}_{5}$ & 24.09 & 26.89 & 23.51 & 22.47 & 21.93 & 24.76 & 26.63 & 25.74 & 22.77 & 26.53 & 24.23 & 24.15 & 25.99 \\
\hline $\mathrm{As}_{2} \mathrm{O}_{5}$ & 0.46 & 0.87 & 0.68 & 0.34 & 1.59 & 0.33 & 0.00 & 0.36 & 1.21 & 2.03 & 0.53 & 0.00 & 0.86 \\
\hline $\mathrm{CO}_{2}$ & 1.46 & 0.00 & 2.12 & 3.02 & 2.66 & 1.59 & 0.00 & 0.00 & 2.02 & 0.00 & 1.19 & 1.27 & 0.45 \\
\hline $\mathrm{Al}_{2} \mathrm{O}_{3}$ & 28.76 & 29.49 & 27.14 & 27.14 & 26.69 & 27.61 & 28.15 & 27.24 & 28.18 & 29.16 & 27.14 & 26.05 & 29.36 \\
\hline $\mathrm{Fe}_{2} \mathrm{O}_{3}$ & 3.21 & 1.63 & 4.02 & 4.17 & 5.15 & 2.22 & 0.96 & 1.10 & 2.80 & 1.02 & 1.91 & 2.27 & 0.78 \\
\hline $\mathrm{La}_{2} \mathrm{O}_{3}$ & 3.93 & 5.23 & 5.95 & 4.13 & 5.09 & 5.65 & 7.61 & 7.93 & 5.47 & 5.53 & 4.94 & 5.08 & 9.12 \\
\hline $\mathrm{Ce}_{2} \mathrm{O}_{3}$ & 9.25 & 8.63 & 10.42 & 7.79 & 9.98 & 11.06 & 13.39 & 13.36 & 10.74 & 10.97 & 11.03 & 10.89 & 13.03 \\
\hline $\mathrm{Pr}_{2} \mathrm{O}_{3}$ & 1.26 & 0.69 & 0.91 & 0.68 & 1.04 & 0.98 & 1.40 & 1.17 & 1.24 & 1.28 & 1.17 & 1.50 & 1.07 \\
\hline $\mathrm{Nd}_{2} \mathrm{O}_{3}$ & 3.12 & 2.47 & 2.80 & 2.55 & 3.31 & 3.85 & 3.04 & 3.56 & 3.75 & 5.28 & 4.47 & 4.25 & 2.88 \\
\hline $\mathrm{Sm}_{2} \mathrm{O}_{3}$ & 0.52 & 0.26 & 0.26 & 0.37 & 0.60 & 0.43 & 0.38 & 0.43 & 0.75 & 0.84 & 0.94 & 0.81 & 0.56 \\
\hline $\mathrm{Eu}_{2} \mathrm{O}_{3}$ & 0.12 & 0.19 & 0.00 & 0.11 & 0.08 & 0.20 & 0.20 & 0.18 & 0.00 & 0.22 & 0.31 & 0.18 & 0.14 \\
\hline $\mathrm{Gd}_{2} \mathrm{O}_{3}$ & 0.19 & 0.19 & 0.00 & 0.20 & 0.00 & 0.26 & 0.00 & 0.24 & 0.00 & 0.41 & 0.54 & 0.34 & 0.18 \\
\hline $\mathrm{CaO}$ & 1.13 & 2.25 & 2.61 & 3.91 & 2.87 & 3.22 & 1.27 & 0.81 & 1.92 & 2.24 & 2.30 & 2.56 & 1.04 \\
\hline $\mathrm{SrO}$ & 6.65 & 1.60 & 1.28 & 2.77 & 0.93 & 0.66 & 0.34 & 0.43 & 1.28 & 0.39 & 0.52 & 0.56 & 0.43 \\
\hline $\mathrm{BaO}$ & 0.31 & 1.70 & 1.81 & 2.28 & 0.75 & 1.19 & 0.32 & 0.31 & 0.96 & 0.00 & 1.09 & 1.22 & 0.00 \\
\hline bO & 0.00 & 0.93 & 0.35 & 0.60 & 0.61 & 0.29 & 0.00 & 0.00 & 0.30 & 0.44 & 0.00 & 0.36 & 0.22 \\
\hline $\mathrm{H}_{2} \mathrm{O}$ & 10.83 & 10.33 & 10.52 & 10.24 & 10.50 & 10.51 & 10.15 & 9.92 & 10.47 & 10.58 & 10.14 & 9.98 & 10.44 \\
\hline $\mathrm{F}$ & 0.00 & 0.40 & 0.00 & 1.04 & 0.00 & 0.00 & 0.00 & 0.00 & 0.00 & 0.00 & 0.00 & 0.00 & 0.00 \\
\hline $\mathrm{O}=\mathrm{F}$ & 0.00 & -0.17 & 0.00 & -0.44 & 0.00 & 0.00 & 0.00 & 0.00 & 0.00 & 0.00 & 0.00 & 0.00 & 0.00 \\
\hline Total & 97.25 & 93.97 & 94.71 & 94.10 & 94.22 & 94.91 & 93.97 & 93.10 & 94.69 & 97.38 & 92.63 & 91.51 & 96.76 \\
\hline$\overline{\mathrm{S}^{6+}}$ & 0.122 & 0.024 & 0.021 & 0.046 & 0.028 & 0.006 & 0.009 & 0.022 & 0.053 & 0.029 & 0.012 & 0.003 & 0.014 \\
\hline $\mathrm{P}^{5+}$ & 1.693 & 1.939 & 1.701 & 1.594 & 1.589 & 1.793 & 1.997 & 1.975 & 1.656 & 1.907 & 1.819 & 1.841 & 1.894 \\
\hline $\mathrm{As}^{5+}$ & 0.020 & 0.039 & 0.030 & 0.015 & 0.071 & 0.015 & 0.000 & 0.017 & 0.054 & 0.090 & 0.025 & 0.000 & 0.039 \\
\hline $\mathrm{C}^{4+}$ & 0.165 & 0.000 & 0.247 & 0.345 & 0.311 & 0.186 & 0.000 & 0.000 & 0.237 & 0.000 & 44 & 0.156 & 0.053 \\
\hline$T$ sur & 2.000 & 02 & 2.000 & 2.000 & 2.000 & 2.000 & 2.006 & 2.014 & 2.000 & 2.027 & 00 & 2.000 & 2.000 \\
\hline$\overline{\mathrm{Al}^{3+}}$ & 2.813 & 2.961 & 2.734 & 2.680 & 2.693 & 2.784 & 2.939 & 2.910 & 2.852 & 2.918 & 2.837 & 2.764 & 2.979 \\
\hline $\mathrm{Fe}^{3+}$ & 0.201 & 0.105 & 0.259 & 0.263 & 0.331 & 0.143 & 0.064 & 0.075 & 0.181 & 0.065 & 0.128 & 0.154 & 0.050 \\
\hline$B$ sum & 3.014 & 3.066 & 2.993 & 2.943 & 3.024 & 2.927 & 3.003 & 2.985 & 3.033 & 2.984 & 2.964 & 2.918 & 3.030 \\
\hline$\overline{\mathrm{La}^{3+}}$ & 0.120 & 0.164 & 0.188 & 0.128 & 0.161 & 0.178 & 0.249 & 0.265 & 0.173 & 0.173 & 0.162 & 0.169 & 0.290 \\
\hline $\mathrm{Ce}^{3+}$ & 0.281 & 0.269 & 0.326 & 0.239 & 0.313 & 0.346 & 0.434 & 0.443 & 0.338 & 0.341 & 0.358 & 0.359 & 0.411 \\
\hline $\mathrm{Pr}^{3+}$ & 0.038 & 0.021 & 0.028 & 0.021 & 0.032 & 0.031 & 0.045 & 0.039 & 0.039 & 0.040 & 0.038 & 0.049 & 0.034 \\
\hline $\mathrm{Nd}^{3+}$ & 0.092 & 0.075 & 0.085 & 0.076 & 0.101 & 0.118 & 0.096 & 0.115 & 0.115 & 0.160 & 0.142 & 0.137 & 0.089 \\
\hline $\mathrm{Sm}^{3+}$ & 0.015 & 0.008 & 0.008 & 0.011 & 0.018 & 0.013 & 0.012 & 0.013 & 0.022 & 0.025 & 0.029 & 0.025 & 0.017 \\
\hline $\mathrm{Eu}^{3+}$ & 0.003 & 0.006 & 0.000 & 0.003 & 0.002 & 0.006 & 0.006 & 0.006 & 0.000 & 0.006 & 0.009 & 0.006 & 0.004 \\
\hline $\mathrm{Gd}^{3+}$ & 0.005 & 0.005 & 0.000 & 0.006 & 0.000 & 0.007 & 0.000 & 0.007 & 0.000 & 0.012 & 0.016 & 0.010 & 0.005 \\
\hline $\mathrm{Ca}^{2+}$ & 0.100 & 0.205 & 0.239 & 0.351 & 0.263 & 0.295 & 0.121 & 0.079 & 0.177 & 0.204 & 0.219 & 0.247 & 0.096 \\
\hline $\mathrm{Sr}^{2+}$ & 0.320 & 0.079 & 0.063 & 0.135 & 0.046 & 0.033 & 0.017 & 0.023 & 0.064 & 0.019 & 0.027 & 0.029 & 0.021 \\
\hline $\mathrm{Ba}^{2+}$ & 0.010 & 0.057 & 0.061 & 0.075 & 0.025 & 0.040 & 0.011 & 0.011 & 0.032 & 0.000 & 0.038 & 0.043 & 0.000 \\
\hline $\mathrm{Pb}^{2+}$ & 0.000 & 0.021 & 0.008 & 0.014 & 0.014 & 0.007 & 0.000 & 0.000 & 0.007 & 0.010 & 0.000 & 0.009 & 0.005 \\
\hline A sum & 0.986 & 0.911 & 1.006 & 1.057 & 0.976 & 1.073 & 0.991 & 1.001 & 0.967 & 0.990 & 1.036 & 1.082 & 0.971 \\
\hline$\overline{\mathrm{OH}^{-}}$ & 6.001 & 5.895 & 6.004 & 5.728 & 6.001 & 6.002 & 6.003 & 6.003 & 6.003 & 5.998 & 6.003 & 5.999 & 6.001 \\
\hline $\mathrm{F}^{-}$ & 0.000 & 0.107 & 0.000 & 0.276 & 0.000 & 0.000 & 0.000 & 0.000 & 0.000 & 0.000 & 0.000 & 0.000 & 0.000 \\
\hline $\mathrm{OH}+\mathrm{F}$ & 6.001 & 6.002 & 6.004 & 6.003 & 6.001 & 6.002 & 6.003 & 6.003 & 6.003 & 5.998 & 6.003 & 5.999 & 6.001 \\
\hline Flo-REE & 56.3 & 60.2 & 63.1 & 45.7 & 64.3 & 65.1 & 85.0 & 88.8 & 71.1 & 76.4 & 72.7 & 69.7 & $\overline{87.4}$ \\
\hline Cra & 10.2 & 22.5 & 23.8 & 33.2 & 27.0 & 27.5 & 12.2 & 7.9 & 18.3 & 20.6 & 21.1 & 22.8 & 9.9 \\
\hline Goy & 32.5 & 8.7 & 6.3 & 12.7 & 4.7 & 3.1 & 1.8 & 2.3 & 6.6 & 1.9 & 2.6 & 2.7 & 2.2 \\
\hline Gor & 1.0 & 6.2 & 6.0 & 7.1 & 2.6 & 3.7 & 1.1 & 1.1 & 3.3 & 0.0 & 3.7 & 4.0 & 0.0 \\
\hline Pbg & 0.0 & 2.3 & 0.8 & 1.3 & 1.4 & 0.6 & 0.0 & 0.0 & 0.7 & 1.0 & 0.0 & 0.8 & 0.5 \\
\hline $\mathrm{La}_{\mathrm{N}} / \mathrm{Sm}_{\mathrm{N}}$ & 4.7 & 12.5 & 14.2 & 6.9 & 5.2 & 8.1 & 12.4 & 11.4 & 4.5 & 4.1 & 3.3 & 3.9 & 10.1 \\
\hline $\mathrm{Eu} / \mathrm{Eu}^{*}$ & 1.16 & 2.61 & - & 1.23 & $>0.76$ & 1.81 & $>2.39$ & 1.70 & - & 1.14 & 1.32 & 1.04 & 1.34 \\
\hline $\mathrm{Ce} / \mathrm{Ce}^{*}$ & 1.00 & 1.09 & 1.07 & 1.12 & 1.04 & 1.13 & 0.98 & 1.05 & 0.99 & 0.99 & 1.10 & 0.95 & 1.00 \\
\hline
\end{tabular}


normalizované distribuce REE ve florencitu jsou ilustrovány na obr. 35. Vyznačují se obvyklým plynulým poklesem od La ke Gd. Ce anomálie bud' chybí nebo je nevýrazná $\left(\mathrm{Ce} / \mathrm{Ce}^{*}=0.98-1.12\right)$, Eu anomálie je slabě až výrazně pozitivní $\left(E u / E u^{*}=1.04-2.61\right)$. Rozsah frakcionace REE je poměrně značný $\left(\mathrm{La}_{\mathrm{CN}} / \mathrm{Sm}_{\mathrm{CN}}=3.25-14.15\right)$, což nepochybně souvisí s prítomností zvýšených koncentrací $\mathrm{F}$ a eventuálně i $\mathrm{CO}_{2} v$ matečných roztocích. Fluoridové, karbonátové $\left(\mathrm{CO}_{3}^{2-}\right) \mathrm{a} \mathrm{OH}$ anionty mají podle experimentálních údajů největší potenciál pro efektivní frakcionaci REE v hydrotermálních roztocích (např. Wood 1990; Bau 1991; Bau, Möller 1992). Výrazná pozitivní Eu anomálie nasvědčuje bud' poklesu teploty hydrotermálních roztoků pod cca $200{ }^{\circ} \mathrm{C}$, při níž za podmínek běžného hydrotermálního roztoku dochází $\mathrm{k}$ termochemické oxidaci $\mathrm{Eu}^{2+}$ na $\mathrm{Eu}^{3+}$, které již může být rozměrově vázáno ve strukturách Ca-minerálů (Sverjensky 1984; Bau, Möller 1992), nebo je výsledkem zvýšení redox-potenciálu matečných fluid s původně nízkým Eh (např. Bau 1991; Bau, Möller 1992; Lee et al. 2003). Druhé uvedené možnosti by nasvědčovala i prítomnost $\mathrm{Fe}^{3+}$ ve studovaných minerálech plumbogummitové skupiny stejně jako zvýšené koncentrace redox-senzitivních prvků ve vysokých oxidačních stavech (síry a arsenu). Možné otevření systému pro fluida se zvýšeným obsahem volného kyslíku je podporováno také parageneticky pozdní pozicí minerálů plumbogummitové skupiny, které vytvářejí výplně drobných dutin $v$ žilovině nebo často i drobných žilek protínajících žilovinu.

Supergenní mineralizace této lokality je chudá. Vedle hnědých limonitových povlaků byl zjištěn pouze velmi hojný skorodit, který vzniká přeměnou arsenopyritu. Tvoří většinou bledě šedozelené bradavčité povlaky, které obalují úlomky zrudněných rul a křemenné žiloviny. Skorodit též vyplňuje drobné trhliny a dutiny $v$ částečně alterovaném rudním materiálu. Zachycen byl i $v$ analyzovaných nábrusech žiloviny. Při studiu jeho chemického složení (tab. 16, anal. 1 - 5) bylo v kationtové části vedle převládajícího Fe zjištěno i minoritní zastoupení Bi (0.020 - 0.023 $a p f u)$ a Al (0.043 - 0.055 apfu). V aniontové části se vedle dominantního obsahu As uplatňují v malém množství $P$ (0.017 - 0.022 apfu) a S (0.005 - 0.008 apfu). Empirický vzorec skoroditu z Jedové jámy (průměr pěti bodových analýz) je možno vyjádřit jako $\left(\mathrm{Fe}^{3+}{ }_{092} \mathrm{Al}_{005}\right.$ $\left.\mathrm{Bi}_{0.02}\right)_{\Sigma 0.99}\left[\left(\mathrm{As}_{0.98} \mathrm{P}_{0.01} \mathrm{~S}_{0.01}\right)_{\Sigma 1.00} \mathrm{O}_{4.00}\right] \cdot 2 \mathrm{H}_{2} \mathrm{O}$. Vzácněji byly na trhlinách rudniny spolu se skoroditem zjištěny produkty supergenní přeměny izomorfní řady skorodit-strengitu, ve kterých se $v$ aniontové části významně uplatňuje vedle As i P (tab. 16, anal. 6 - 10). $V$ několika analýzách, ve kterých obsahy $P$ (0.547 - 0.563 apfu) převažují nad As, jde již o strengit (obr. 36 ).

Obr. 35 Chondritem normalizované distribuce prvků vzácných zemin ve florencitech z Jedové jámy.

\section{Závěr}

Na opuštěném ložisku arsenové mineralizace, která byla $\vee$ minulosti těžena dolem Drei König, známým též jako Giftschacht (Jedová jáma), cca 2 km jv. od Vejprt, byla nově zjištěna neobyčejně bohatá minerální asociace zahrnující celkem 27 minerálních fází, která je obsažena v křemenné žilovině. Jde především o sulfidy a sulfosoli (16 plus 1 nepojmenovaný), mezi kterými s velkou převahou dominuje arsenopyrit, který je patrně nejstarším sulfidem ložiska. Vedle běžných sulfidů (chalkopyrit, sfalerit, galenit a minerály tetraedritové skupiny) se ve zrudnění uplatňuje pestrá paleta sulfidů a sulfosolí s obsahem Bi. Vedle relativně běžných, jako jsou bismutinit a emplektit, tu byly zjištěny i poměrně vzácné Bi fáze (matildit, aikinit, hammarit, wittichenit), které se $v$ ČR vyskytly jen na nevelkém počtu lokalit. $\mathrm{Bi}$ je tu vázán $\mathrm{i} v$ poměrně řídkém selenidu bohdanowitzitu. Ojediněle byl v nábrusech zjištěn i ryzí bismut. Bismut se tu v hojné míře uplatňuje i v některých tetraedritových partiích (tetraedrit- $(Z n)$, tennantit-(Zn) a tennantit-(Fe)). Vedle lokálně zvýšených obsahů $\mathrm{Bi}$ se $v$ rudnině uplatňuje cínové zrudnění, vázané zčásti na kasiterit, zčásti na poměrně vzácné sulfidické fáze (kësterit a stanoidit). K neobyčejné minerální pestrosti přispívá i prítomnost fosfátů plumbogummitové skupiny (plumbogummit, goyazit a florencit-(Ce)). Z geochemického hlediska je zajímavá prítomnost florencitu(Ce), ve kterém jsou vázány prvky vzácných zemin (REE) $\mathrm{s}$ dominujícím cerem. $Z$ dalších minerálů byla $v$ křemenné žilovině přítomna zrna fluoritu $s$ významnější príměsí $Y$, fluorapatitu, rutilu a agregáty illitu a minerálu z kaolinitové skupiny. Poměrně chudá je na ložisku supergenní mineralizace reprezentovaná vedle limonitu pouze hojným skoroditem a vzácným strengitem.

Z ložiskového hlediska jde o sice drobný, ale neobvyklý kombinovaný typ zrudnění, které nemá v krušnohorském regionu obdobu. $\mathrm{K}$ nejstarší hydrotermální As mineralizaci, reprezentované arsenopyritem, se přidružuje mladší fáze zrudnění se zvýšenými obsahy $\mathrm{Bi}$ a Sn. Přítomnost malého množství topazu, kasiteritu a W-bohatého rutilu by mohla také naznačovat prítomnost starší mineralizace, která je $v$ Krušných horách běžně popisována $\mathrm{z}$ prostředí greisenů.

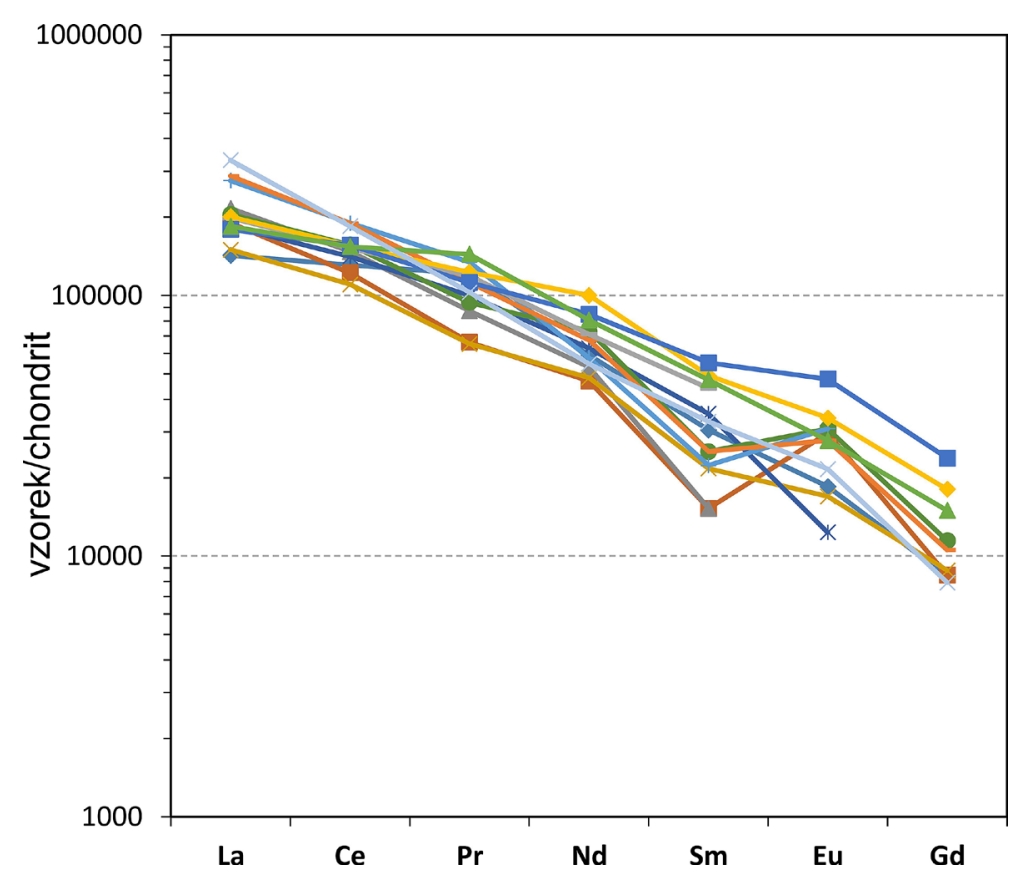


Tabulka 16 Chemické složení skoroditu (Sko) a strengitu (Str) z Jedové jámy ( $\mathrm{hm}$. \%). Koeficienty empirických vzorců počitány na bázi As $+\mathrm{P}+\mathrm{S}=1$ apfu; $\mathrm{H}_{2} \mathrm{O}^{*}$ - dopočtený obsah na základě ideálního obsahu $2 \mathrm{H}_{2} \mathrm{O}$.

\begin{tabular}{lrrrrrrrrrrr}
\hline An. Č. & mean & 1 & 2 & 3 & 4 & 5 & 6 & 7 & 8 & 9 & 10 \\
Minerál & Sko & Sko & Sko & Sko & Sko & Sko & Sko & Sko & Str & Str & Str \\
\hline $\mathrm{CuO}$ & 0.00 & 0.00 & 0.00 & 0.00 & 0.00 & 0.00 & 0.03 & 0.08 & 0.00 & 0.13 & 0.08 \\
$\mathrm{Fe}_{2} \mathrm{O}_{3}$ & 32.86 & 34.11 & 33.57 & 33.66 & 33.51 & 34.20 & 39.93 & 38.82 & 38.97 & 38.75 & 40.43 \\
$\mathrm{Bi}_{2} \mathrm{O}_{3}$ & 2.28 & 2.31 & 2.17 & 2.31 & 2.29 & 2.50 & 0.00 & 0.00 & 0.00 & 0.00 & 0.00 \\
$\mathrm{Al}_{2} \mathrm{O}_{3}$ & 1.31 & 1.14 & 1.06 & 1.15 & 1.03 & 1.23 & 0.71 & 0.70 & 0.72 & 0.77 & 0.69 \\
$\mathrm{As}_{2} \mathrm{O}_{5}$ & 51.76 & 50.83 & 51.88 & 51.69 & 52.11 & 51.89 & 36.13 & 34.68 & 27.02 & 27.03 & 27.45 \\
$\mathrm{P}_{2} \mathrm{O}_{5}$ & 0.54 & 0.56 & 0.57 & 0.62 & 0.71 & 0.72 & 13.51 & 15.00 & 20.90 & 21.20 & 22.01 \\
$\mathrm{SO}_{3}$ & 0.17 & 0.20 & 0.18 & 0.21 & 0.19 & 0.31 & 0.07 & 0.16 & 0.36 & 0.45 & 0.16 \\
$\mathrm{H}_{2} \mathrm{O}^{*}$ & 16.41 & 16.41 & 16.49 & 16.53 & 16.58 & 16.76 & 18.92 & 18.34 & 19.45 & 18.95 & 19.45 \\
\hline $\mathrm{Total}^{2}$ & 105.33 & 105.56 & 105.92 & 106.17 & 106.42 & 107.61 & 109.30 & 107.78 & 107.69 & 107.28 & 110.27 \\
\hline $\mathrm{Cu}^{2+}$ & 0.000 & 0.000 & 0.000 & 0.000 & 0.000 & 0.000 & 0.001 & 0.002 & 0.000 & 0.004 & 0.002 \\
$\mathrm{Fe}^{3+}$ & 0.894 & 0.940 & 0.911 & 0.922 & 0.901 & 0.920 & 0.988 & 0.945 & 0.907 & 0.968 & 0.918 \\
$\mathrm{Bi}^{3+}$ & 0.022 & 0.022 & 0.020 & 0.022 & 0.021 & 0.023 & 0.000 & 0.000 & 0.000 & 0.000 & 0.000 \\
$\mathrm{Al}^{3+}$ & 0.055 & 0.049 & 0.045 & 0.049 & 0.043 & 0.052 & 0.028 & 0.027 & 0.026 & 0.029 & 0.025 \\
\hline$\Sigma$ kationt & 0.971 & 1.011 & 0.976 & 0.993 & 0.965 & 0.995 & 1.017 & 0.974 & 0.933 & 1.001 & 0.945 \\
\hline $\mathrm{As}^{5+}$ & 0.978 & 0.978 & 0.978 & 0.983 & 0.973 & 0.970 & 0.621 & 0.586 & 0.438 & 0.436 & 0.433 \\
$\mathrm{P}^{5+}$ & 0.017 & 0.017 & 0.017 & 0.011 & 0.022 & 0.022 & 0.377 & 0.410 & 0.547 & 0.553 & 0.563 \\
$\mathrm{~S}^{6+}$ & 0.005 & 0.005 & 0.005 & 0.006 & 0.005 & 0.008 & 0.002 & 0.004 & 0.015 & 0.011 & 0.004 \\
\hline$\Sigma$ aniont & 1 & 1 & 1 & 1 & 1 & 1 & 1 & 1 & 1 & 1 & 1 \\
$\mathrm{H}_{2} \mathrm{O}$ & 2 & 2 & 2 & 2 & 2 & 2 & 2 & 2 & 2 & 2 & 2 \\
\hline
\end{tabular}

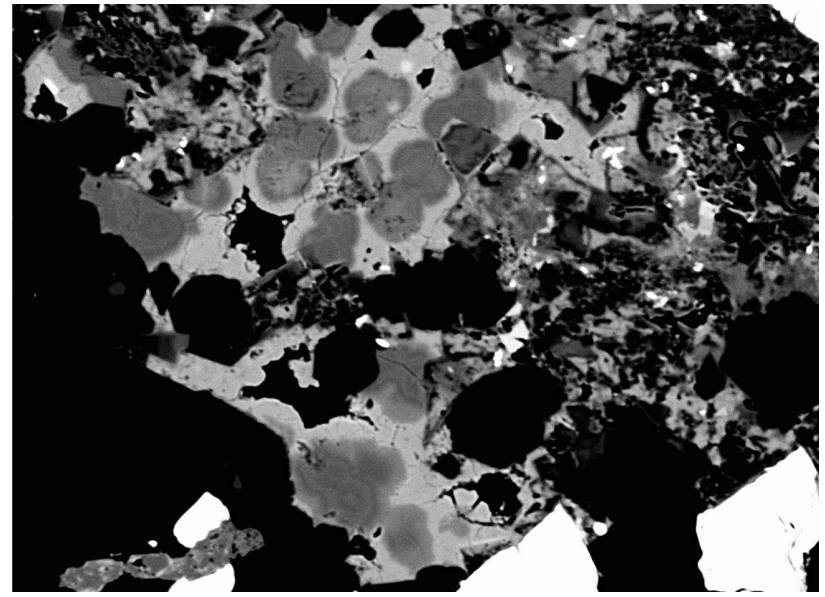

\section{Poděkování}

Autoři děkuji za pořízení fotografií minerálů Petru Fuchsovi a Bohuslavu Burešovi, za kritické pročtení rukopisu panu prof. Ferry Fediukovi a recenzentům Tomáši Mikušovi a Martinu Števkovi a editorovi J. Sejkorovi za kritické poznámky a doporučení, které vedly ke zkvalitnění rukopisu.

Předložená práce vznikla za finanční podpory Ministerstva kultury $v$ rámci institucionálního financování dlouhodobého koncepčního rozvoje výzkumné organizace Národní muzeum (DKRVO 2019-2023/1.I.b, 00023272).

\section{Literatura}

Anders E, Grevesse N (1989) Abundances of the elements: Meteoritic and solar. Geochim Cosmochim Acta 53: 197-214

BAU M (1991) Rare-earth element mobility during hydrothermal and metamorphic fluid-rock interaction and the significance on the oxidation state of europium. Chem Geol 93: 219-230

BAu M, Möller P (1992) Rare earth element fractionation in metamorphogenic hydrothermal calcite, magnesite and siderite. Miner Petrol 45: 231-246
Obr. 36 Agregát skoroditu (světle šedý) a strengitu (tmavě šedý) s arsenopyritem (bilý); Jedová jáma; šiřka záběru 320 m, foto v BSE Z. Dolníček.

BERAN P (1999) Nerosty cíno-wolframových ložisek Slavkovského lesa. Okresní muzeum a knihovna Sokolov Breiter K, ŠKoda R, Veselovský F (2009) Neobvyklý P-, Li- a Sn-bohatý pegmatit z Vernéřova u Aše, Česká republika. Bull mineral-petrolog Odd Nár Muz (Praha) 17(1): 41-59

David J, Dašek J, Slačík J, Henych R, ŽÁček J (1991) Závěrečná likvidační zpráva Cínovec-jih, stav k 31.12. 1991. MS, Rudné doly Teplice, archiv ČGS - Geofond, Praha

GrambličKa R, Kunz M, Pour O (2015) Důl Jedová jáma u Vejprt v Krušných horách. Minerál 23(4): 352-356

HRABÁNEK J (2006) Historie hornictví ve městě Vejprty a jeho okolí. Minerál 14(3): 197-200

Chlupáč I, Brzobohatý R, Kovanda J, Stráník Z (2011) Geologická minulost České republiky. Academia Praha

JaKovLEV JuN, DuBAKINA LS, BYKov VP (1972) Occurrence of parkerite in copper-nickel ores of the Allarchensk region, Murmansk district. Dokl Akad Nauk SSSR 203: 1382-1385 ( $v$ ruštině)

JANGL L (1957) Zpráva o výsledcích báňskohistorického výzkumu Vejprty. MS, archív ČGS - Geofond Praha P 8807 
JoKÉLY J (1857) Die geologische Beschaffenheit des Erzgebirges im Saazer Kreis in Böhmen. Jb der k-k Geol Reichsanstalt (Wien) 8: 516-607

Kocourková E, Houzar S, Hrazdil V (2010) Pyromorfit z jihlavského rudního revíru. Acta Mus Moraviae, Sci geol 95: 105-120

KoŘAN J (1947) Historická zpráva o Vejprtském dolování. MS, archiv ČGS - Geofond Praha P 314

KovÁR̆ M (2012) Mineralogická charakteristika sulfidických greisenů Sn-W revíru Horní Slavkov. MS, bakalářská práce, PřF UP Olomouc

KotlánovÁ M, Dolní̌Ek Z, Kapusta J (2016) Minerály vzácných zemin na hydrotermálních polymetalických žilách z historického ložiska Zlatý důl u Hluboček Mariánského Údolí (kulm Nízkého Jeseníku). Bull mineral-petrolog Odd Nár Muz (Praha) 24(1): 70-79

Kučera J, KuČerová-Charvátová K, ŠKoda R (2007) Nové výskyty minerálů na hydrotermálních žilách Nízkého Jeseníku (II). Bull mineral-petrolog Odd Nár Muz (Praha) 14-15: 66-68

KVAČEK M (1979) Selenides from the uranium deposits of Western Moravia, Czechoslovakia, part 2. Acta Univ Carol, Geol 1-2: 15-38

LAUGIER J, BOCHU B (2011) LMGP-suite of programs for the interpretation of X-ray experiments. http://www.ccp14. ac.uk/tutorial/Imgp, přístup duben 2011

Lee SG, Lee DH, Kim Y, Chae BG, Kim WY, Woo NCh (2003) Rare earth elements as indicators of groundwater environment changes in a fractured rock system: evidence from fracture - filling calcite. Appl Geoch 18: 135-143

LIENERT H (1971) Závěrečná zpráva Krušné hory - střed 5120311 004, surovina fluorit. MS Geoindustria Praha

MaLkovský M a kolektiv (1985) Geologie severočeské hnědouhelné pánve a jejího okolí. Ústř Ústav geol, Praha

MAYerová L, MAYER P (1967) Závěrečná zpráva, Krušné hory, prospekce 513311001 , surovina fluorit. MS, archiv ČGS - Geofond, P 20608

McLenNAn SM (1989) Rare earth elements in sedimentary rocks: influence of provenance and sedimentary processes. Rev Mineral 21: 169-200

NovÁK F, JANSA J, PrachaŘ I (1989) Florencit-(Ce) ze Suché Rudné v Jeseníkách. Věst Ústř Úst geol 64: 163171

Ondruš P, Veselovský F, Gabašová A, Hloušek J, Šrein V, VavŘín I, Skála R, Sejkora J, Drábek M (2003) Primary minerals of the Jáchymov ore district. J Czech Geol Soc 48(3-4): 19-147

PAVLU D (1984) Djurleite and stannoidite from tin-tungsten deposit at Krásno nad Teplou (Czechoslovakia). Věst Ústř Úst geol 59(6): 351-354

PlášIL J, SEJKora J, ČEJKa J, ŠKoda R, Goliáš V (2009) Supergene mineralization of the Medvědín uranium deposit, Krkonoše Mountains, Czech Republic. J Geosci 54: $15-56$

Pouchou JL, PICHOIR F (1985) "PAP" ( $\varphi \rho Z)$ procedure for improved quantitative microanalysis. In: Microbeam analysis (J. T. Armstrong, ed.). San Francisco Press, San Francisco, 104-106
PrAChAŘ I (1979) Aikinit z Krupky. Acta Univ Carol, Geol 3-4: 183-186

Rieder M, Cavazzini G, D'yakonov YS, Kamenetskil VAF, Gottardi G, Guggenheim S, Koval' PV, Mueller G, NelVA AMR, RadosLovich EW, Robert JL, SASSI FP, TAKeda H, WeIsS Z, Wones DR (1998) Nomenclature of micas. Can Mineral 36: 905-912

Scharm B, Scharmová M, Kundrát M (1994) Crandallite group minerals in the uranium ore district of Northern Bohemia (Czech Republic). Věst Čes Geol Úst 69(1): 79-85

Sejkora J, ČEJKa J, Šrein V, Novotná M, Ederová J (1998) Minerals of the plumbogummite - philipsbornite series from Moldava deposit, Krušné hory Mts., Czech Republic. N Jb Mineral, Mh 4: 145-163

SeJKoRA J, Litochleb J (2009) První výskyt Sn-sulfidů v jílovském zlatonosném revíru (Česká republika). Bull mineral-petrolog Odd Nár Muz (Praha) 17(1): 91-94

SEJKoRA J, PAulIš P, ŠKodA R (2007) Uranové ložisko Zálesí v Rychlebských horách. Minerál 15(4): 305-328

Sejkora J, ŠKoda R, Ondruš P, Beran P, Süsser C (2006) Mineralogy of phosphate accumulations in the Huber stock, Krásno ore district, Slavkovský les area, Czech Republic. J Czech Geol Soc 51(1-2): 103-147

SEJKora J, ŠKodA R, ŠKÁCHA P, BuREš B, DVOŘÁK Z (2009) Nové mineralogické nálezy na Sn-W ložisku Cínovec v Krušných horách (Česká republika). Bull mineral-petrolog Odd Nár Muz (Praha) 17(2): 23-30

SEJKORA J, ŠKÁCHA P (2015) Selenidy z fluoritového ložiska Moldava v Krušných horách (Česká republika). Bull mineral-petrolog Odd Nár Muz (Praha) 23(2): 229-241

SeJKora J, Šrein V, Šreinová B, Dolniček Z (2017) Selenidová mineralizace uranového ložiska Potůčky v Krušných horách (Czech Republic). Bull Mineral Petrolog 25(2): 306-317

SVERJENSKY DA (1984) Europium redox equilibria in aqueous solution. Earth Planet Sci Lett 67: 70-78

Šrein V, Šreinová B, SEJKora J, ŠŤastný M, Kolman B (2007) Mineralogická charakteristika metasomatického rudního ložiska Malovidy u Českého Šternberka. Bull mineral-petrolog Odd Nár Muz (Praha) 14-15: 149-158

Števko M, Uher P, Ondrejka M, Ozdín D, Bačík P (2014) Quartz-apatite-REE phosphates-uraninite vein mineralization near Čučma (eastern Slovakia): a product of early Alpine hydrothermal activity in the Gemeric Superunit, Western Carpathians. J Geosci 59: 209-222

VeLEBIL D, PŘIBIL M (2012) Historické stříbrnorudné ložisko Vejprty v Krušných horách: geologické, ložiskové a mineralogické poměry, topografie dolů a historie dolování. Bull mineral-petrolog Odd Nár Muz (Praha) 20(1): 63-82

Velebil D, Sejkora J (2018) Bismutem bohaté tennantity z Jáchymova (Česká republika). Bull Mineral Petrolog 26(2): 213-222

Wood SA (1990) The aqueous geochemistry of rare earth elements and yttrium. 2. Theoretical predictions of speciation in hydrothermal solutions to $350^{\circ} \mathrm{C}$ at saturated water pressure. Chem Geol 88: 99-125 